LUCILA MARIA PASTORELLO

\title{
Leitura em voz alta e apropriação da linguagem escrita pela criança
}

Tese apresentada ao programa de pós-graduação da

Faculdade de Educação da Universidade de São Paulo, como parte dos requisitos para obtenção do título de Doutor em Educação.

Área de concentração Educação e Linguagem

Orientador: Prof. Dr. Claudemir Belintane

São Paulo

2010 
Autorizo a reprodução e divulgação total ou parcial deste trabalho, por qualquer meio convencional ou eletrônico, para fins de estudo e pesquisa, desde que citada a fonte.

Catalogação na Publicação

Serviço de Biblioteca e Documentação

Faculdade de Educação da Universidade de São Paulo

372.9 Pastorello, Lucila Maria

P293L Leitura em voz alta e apropriação da linguagem escrita pela criança / Lucila Maria Pastorello ; orientação Claudemir Belintane. São Paulo : s.n., 2010. 150 p. il.

Tese (Doutorado - Programa de Pós-Graduação em Educação.Área de Concentração : Educação e Linguagem) - - Faculdade de Educação da Universidade de São Paulo.

1. Leitura - Aquisição 2. Escrita - Aquisição 3. Aquisição da linguagem 4. Ensino e aprendizagem 5. Psicopedagogia I. Belintane, Claudemir, orient. 


\section{FOLHA DE APROVAÇÃO}

\section{Lucila Maria Pastorello \\ Leitura em voz alta \\ e apropriação da linguagem escrita pela criança}

Tese apresentada ao programa de pós-graduação da Faculdade de Educação da Universidade de São Paulo, como parte dos requisitos para obtenção do título de Doutor em Educação.

Área de concentração Educação e Linguagem

Aprovado em :

Banca Examinadora

Prof.Dr.

Instituição:

Assinatura:

Prof.Dr.

Instituição:

Assinatura:

Prof.Dr.

Instituição: Assinatura:

Prof.Dr.

Instituição:

Assinatura:

Prof.Dr.

Instituição: Assinatura: 
Ao Pedro e à Mariana: Vocês me ensinam que voltar à infância faz parte de amadurecer.

Eu uso óculos para reler Monteiro Lobato, Julio Verne, Jorge

Amado. Herbert Viana, outubro de 2009

Ao Marcos, pela companhia e cuidado em dar contornos ao meu tempo: Agora vamos descansar, $\mathrm{Lu}$. 


\section{Agradecimentos}

Às crianças com as quais trabalho e às detentas que participaram da oficina "Brincar de ler" no presídio de Santana, muito obrigada pela companhia inspiradora.

Ao suporte de toda minha família: mãe, pai, tia, irmãs, sobrinhos, cunhados, compadre e comadre.

Ao Claudemir Belintane, pela paciência atenta e transformadora. Obrigada!

A Angela Vorcaro e Ana Luiza Marcondes Garcia: o olhar de vocês me fez enxergar adiante. Ao Marc Roger, Jean Guiet e Corinne Lemonnier (La Voie des Livres), que me acolheram tão generosamente em Paris, e mudaram meu modo de ver a leitura.

A Valerie Delbore ( Les Mots Parleurs), pelo apoio, confiança e oportunidade de conhecer uma leitura singular.

A Ana Clélia de Oliveira Rocha, comadre e parceira, desde sempre.

Ao elo produtivo e imprescindível: Denize (Casa de Livros), que investiu, acreditou e que levou a Maria Betânia Ferreira (Pingo é Letra), grata descoberta que escreve o que eu penso e que me levou à parceria com Christine Fontelles (Ecofuturo), que faz acontecer aquilo que pensamos.

À Fátima Milnitsky e Ana Tereza Dauden, que além de ouvidos, me deram palavras!

À Paulina Schmidtbauer Rocha, que generosamente me presenteou com preciosidades.

Às companheiras Cristiane Mori-de Angelis e Denise Teixeira: a saudade me faz escrever.

Ao grupo de pesquisa oralidade/escrita, pela cumplicidade e companheirismo.

À Celeste Correa e Viviane Veras pelas sugestões.

E à Elaine e Adriana, pela força lá em casa.

À FAPESP - Fundação de Amparo à Pesquisa do Estado de São Paulo, pelo financiamento desta pesquisa. 
Se pudéssemos banir todas essas visões preconcebidas quando lemos já teríamos um início admirável. Não dê ordens a seu autor; tente aproximar-se dele. Seja seu colaborador e cúmplice. Se você hesita, e faz restrições e critica logo de início, você impede a si mesmo de alcançar a mais plena possibilidade de avaliar aquilo que lê. Mas se você abre a sua cabeça o máximo possível, então os sinais e as alusões de sutileza quase imperceptível, desde os subterfúgios das primeiras frases, irão colocá-lo diante de um ser humano diferente de qualquer outro.

Virginia Woolf. O leitor comum, 2007, p. 124. 


\section{Resumo}

PASTORELLO, L.M. Leitura em voz alta e apropriação da linguagem escrita pela criança. 2010. 150f. Tese (Doutorado)- Faculdade de Educação, Universidade de São Paulo, São Paulo, 2010.

Partindo do entrecruzamento entre a linguística, a psicanálise e a clínica fonoaudiológica, o presente trabalho tem o objetivo de discutir o papel da leitura em voz alta no processo de apropriação da linguagem pela criança, sustentando a hipótese de que a leitura em voz alta, em função de suas especificidades, interfere positivamente nesse processo. Tomamos a leitura em voz alta em sua dimensão discursiva e subjetivante, que coloca em cena a língua, o corpo e o desejo de quem lê e de quem escuta. Admitimos os processos de apropriação da linguagem sob uma perspectiva não desenvolvimentista, mas que considera tais processos como relativos a diferentes posições subjetivas. Trata-se de uma pesquisa teórica ilustrada por vinhetas da clínica fonoaudiológica e da literatura literária. A partir de nossas reflexões e da discussão teórica, argumentamos que as características da leitura em voz alta - a presencialidade atualizada pela voz e pelo olhar, a convocação do corpo sonoro e seu potencial para transmitir cultura - são significantes e podem interferir positivamente no processo de apropriação da escrita.

Palavras chave: Leitura em voz alta, subjetividade, aquisição da escrita. 


\begin{abstract}
PASTORELLO, L.M. Reading aloud and the writing appropriation by the child 2010 . 150f. Tese (Doutorado)- Faculdade de Educação, Universidade de São Paulo, São Paulo, 2010.
\end{abstract}

Based on the intersection among linguistics, psychoanalysis and clinical practice in speechtherapy treatments, this thesis aims to discuss the role of reading aloud in the process of language appropriation by the child, supporting the hypothesis that reading aloud, due to its specificities, positively interferes in this process. We take reading aloud in its subjectivating and discursive dimension, which calls into play the language, the body and the desire of the one who reads (the reader) and the one who listens (the listener). We assume the processes of language appropriation from a non developmental perspective, but which considers such processes as relative to different subjective positions. This is a theoretical research illustrated with transcripts/vignettes from speechtherapy clinical treatments and excerpts from the literary literature. From our reflections and from the theoretical discussion, we argue that the characteristics of reading aloud - the presentiality updated by the voice and by the look, the summons by the sounding body and its potential to transmit culture - are significant and may positively interfere in the process of writing appropriation.

Key words: reading aloud, subjectivity, acquisition of the writing. 


\section{Sumário}

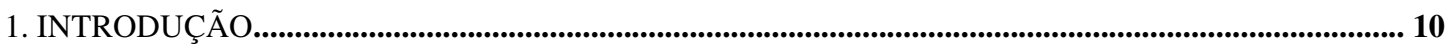

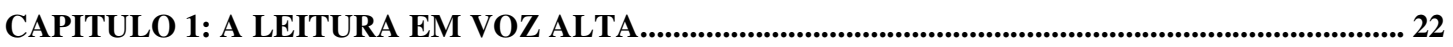

1.1.CONSIDERAÇÕES INICIAIS A RESPEITO DA LEITURA E DA ESCRITA....................................................... 22

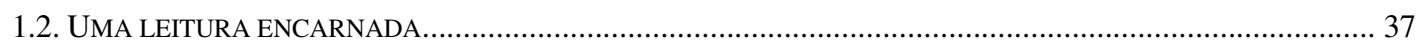

CAPÍTULO 2: LEITURA EM VOZ ALTA E PRODUÇÃO DE SUBJETIVIDADE ............................... 51

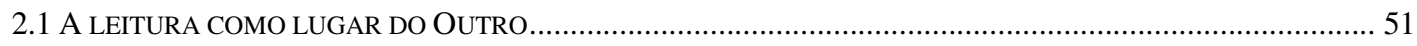

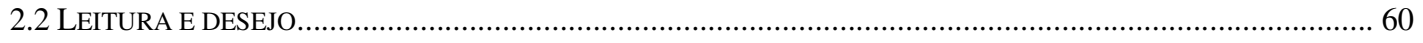

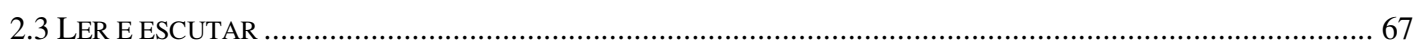

CAPÍTULO 3: CORPO SONORO E LEITURA EM VOZ ALTA ............................................................ 77

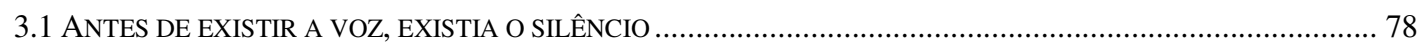

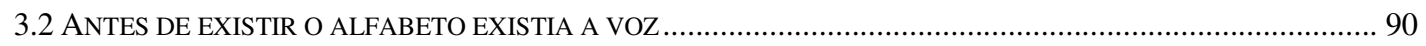

CAPÍTULO 4: A CENA DA LEITURA EM VOZ ALTA....................................................................... 104

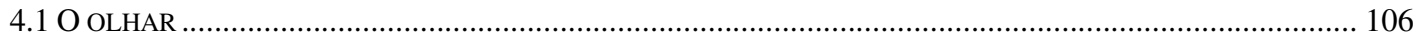

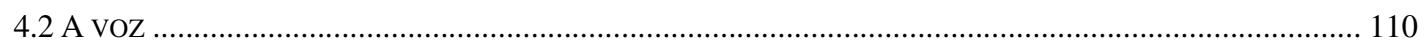

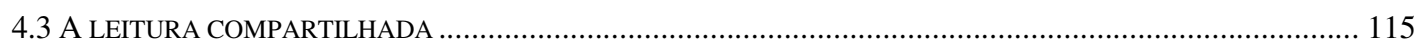

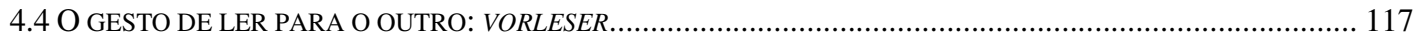

4.5 LER PARA O OUTRO: TESTEMUNHO DE ASSUJEITAMENTO À CULTURA ................................................ 121

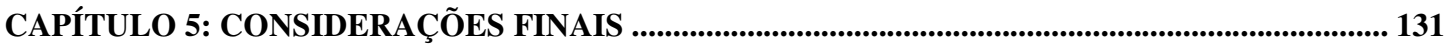

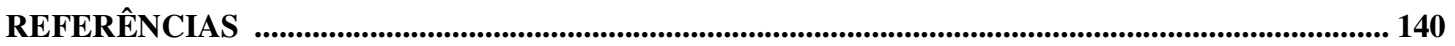




\section{Introdução}

Eu ainda não sabia ler, mas já era bastante esnobe para exigir os meus livros. Meu avô foi ao patife de seu editor e conseguiu de presente Os contos do poeta Maurice Bouchor, narrativas extraídas do folclore e adaptadas ao gosto da infância por um homem que conservava, dizia ele, olhos de criança. Eu quis começar na mesma hora as cerimônias de apropriação. Peguei os dois volumezinhos, cheirei-os, apalpei-os, abri negligentemente na "página certa", fazendo-os estalar. Debalde: eu não tinha a sensação de possuí-los. Tentei sem maior êxito tratá-los como uma boneca, acalentá-los, beijá-los, surrá-los. Quase em lágrimas, acabei por depô-los sobre os joelhos de minha mãe. Ela levantou os olhos de seu trabalho: "O que queres que eu te leia, querido? As Fadas? Perguntei incrédulo: As Fadas estão aî dentro?” Jean Paul Sartre, J.P. As palavras, 1969, p. 30.

Em As Palavras, Sartre oferece um depoimento cuidadoso sobre sua relação com a linguagem, especialmente a escrita, trazendo cenas de sua infância. A epígrafe é ilustradora, por colocar em cena justamente aspectos que mobilizam o presente trabalho: a apropriação da escrita pela criança, o encantamento através da voz, a intimidade e o afeto envolvidos na atividade: Sartre fala do acesso ao texto pelo corpo do outro.

Sempre me ocupei das questões que se impõem na clínica fonoaudiológica, em especial os desvios de linguagem e a subjetividade. O interesse em pesquisar especificamente a leitura e escrita começou a se produzir há cerca de seis anos, a partir da demanda clínica aumento considerável de queixas relativas à leitura e escrita - de práticas de leitura, vividas como voluntária no programa "Biblioteca Viva em Hospitais" 1 e como professora em cursos de graduação em fonoaudiologia.

Neste percurso, localizo cenas que me obrigam a ver e rever questões teóricas que sustentam meu trabalho na clínica. Uma delas - que considero impulsionadoras do presente estudo - teve lugar durante uma sessão de leitura no Hospital São Paulo, enquanto trabalhava como voluntária no programa "Biblioteca Viva em Hospitais". Lia para Jaqueline, uma

\footnotetext{
${ }^{1}$ Programa de Humanização Hospitalar, estruturado a partir de parceria entre a Fundação ABRINQ, Ministério da Saúde e financiadora privada, que utiliza a leitura em voz alta de obras literárias para crianças em ambiente hospitalar. www.fundabrinq.org.br
} 
menina de cerca de cinco anos de idade, cuja escolarização era bastante comprometida em função de recorrentes episódios de pneumonia, que a obrigavam a frequentar assiduamente o Hospital, tanto no pronto atendimento quanto na enfermaria. Durante suas estadias no Hospital, Jaqueline sempre apreciava ouvir as leituras que lhe eram oferecidas.

Na sessão de leitura aque me refiro, a menina tomou o livro de minhas mãos, afirmando que seria ela quem leria então. Jaqueline sentou-se altiva em seu leito, tomou o livro nas mãos e começou a ler. E leu. Sua voz entoava as cantigas de leitura que já havia ouvido da boca dos mediadores de leitura; as frases que pronunciava apresentavam concordâncias e rigor gramatical que não se ouvem na fala, especialmente na chamada fala não-letrada ${ }^{2}$. Jaqueline virava as páginas, respeitando um tempo de leitura, bem como a relação de seu texto verbal com a imagem apresentada no livro. Vez ou outra a menina me lançava um olhar solicitando confirmação, certificando-se de estar sendo bem compreendida. Jaqueline, sem dúvida, imitava a leitura. Será que se pode dizer que este gesto, cheio de saberes sobre a escrita, não representa um lançar-se à escrita, um movimento em direção à apropriação de uma forma específica de discursividade, um ritual de apropriação, como aponta Sartre?

As cenas posteriores, de certa forma, foram sendo percebidas a partir desta primeira. Impactada pelos efeitos da leitura em voz alta observados, estruturei um projeto de extensão na Universidade em que então lecionava, cujo foco era a Humanização dos serviços de saúde da Universidade e de Hospitais conveniados ${ }^{3}$. Nesse projeto, os alunos da Universidade eram capacitados para atuarem como leitores para crianças que se encontravam em condições de sofrimento. Durante os três anos em que funcionou essa atividade, fui colecionando cenas instigantes: bebês de seis, oito, onze meses atentos à leitura, focalizando

\footnotetext{
${ }^{2}$ Fala letrada: termo utilizado por Kato (1999) para descrever os efeitos do letramento sobre a oralidade;
} 
ora o livro, ora a boca e o rosto de quem lia; crianças de 18, 24 meses, fazendo a viragem da página no tempo certo do leitor; enfermeiros, médicos e faxineiros demorando-se mais em seu trabalho, esperando o final da história que era lida. ${ }^{4}$

Mais além dessa experiência, a leitura em voz alta ocupa momentos com meus filhos e na clínica. As crianças que, por algum motivo, tropeçam na apropriação da linguagem, engatam-se como “ouvintes-observadores", que se transmutam em leitores e escritores. Cenas, que são muitas, desfilam em minha memória de forma incessante, chamando por uma escrita, um registro, por uma teorização. O doutorado se apresentou como a possibilidade de pesquisar, criar e registrar.

Animada por estas observações encontrei, surpreendentemente, em conversas com colegas no doutorado na educação, uma desconfiança a respeito da minha temática. Ler em voz alta?

É evidente que a leitura silenciosa, fluida e veloz, deva ser parte dos objetivos - e desafios - da escola atual. É essa leitura, mental, que permite o acesso intensivo e extensivo da escrita e a construção do leitor crítico. É na perda do corpo, da fonemática $e$ da visibilidade da letra, como diz Bergès (1987) que se tem acesso ao sentido.

No campo da educação, a leitura em voz alta está fortemente associada às práticas normativas e prescritivas (como indica Zilberman, 1997 e Kleiman, 1993), a rituais escolares de avaliação de desempenho (Kleiman, 1993; Pennac, 1993) e, mais recentemente, às práticas desenvolvidas pelo método fônico, que entende a leitura como atividade de deciframento da correspondência grafofônica. (Capovilla \& Capovilla, 2002; Fayol e Morais, 2004).

Não identifico meu trabalho com nenhuma dessas práticas. Percebo que o que me interessa é a leitura não-escolarizada: aquela que tem lugar fora da escola (com crianças de qualquer idade), ou antes, fora da fase formal de alfabetização.

\footnotetext{
${ }^{3}$ Os pressupostos e resultados deste projeto estão publicados em Pastorello, 2006 e Pastorello, 2007.
} 
Na atualidade, a escola é a instituição responsável pela alfabetização e pela formalização do aprendizado da leitura e da escrita. A prática escolar confunde-se com a prática da leitura e da escrita. Zilberman é clara: rejeitar a leitura é rejeitar a escola (1997, p. 23). Mas há letras fora da escola. A discussão sobre a "crise da leitura", fenômeno mundial, como nos diz Anne Marie Chartier (2003) é empobrecida, se limitada à escolarização. Colocar em jogo métodos de alfabetização, horas de atividade escolar, formação e remuneração de professores é evidentemente importante. Contudo, responsabilizar apenas a escola pelos fracassos e resistências à leitura é desconsiderar a dimensão cultural, social e subjetivante da linguagem escrita e mais evidentemente, a dimensão histórica que condiciona transformações constantes na prática leitora (Chartier, 2001)

A noção de letramento (Soares, 2009; Barré-De Miniac, 2007; Rojo, 2006(a); Kleiman, 1995) permite avançar nesta reflexão, na medida em que introduz exatamente a dimensão social da leitura e da escrita, extrapola os muros da escola e não focaliza a alfabetização - domínio da tecnologia da decifragem grafema-fonema -, mas os modos de apropriação da escrita. Neste sentido, a criança inicia seu processo de apropriação da escrita fora da escola, antes de ser alfabetizada e para além da escola, após ser alfabetizada ${ }^{5}$, como comenta Rojo, 2006 (b).

Lemos (1998) observa que o discurso sobre as práticas letradas em que a criança se insere deve ser considerado no processo de apropriação da escrita pela criança. É preciso começar pelas práticas discursivas orais em que o texto escrito é significado, passando a fazer sentido como objeto para a criança (1998, p.28).

\footnotetext{
${ }^{4}$ Para mais detalhes sobre as atividades desenvolvidas e seus efeitos, ver Pastorello 2006 e Pastorello 2007.

${ }^{5}$ Numerosos programas de letramento atualmente são desenvolvidos focalizando as crianças de seis meses a cinco anos, como a "Biblioteca Viva em Hospitais," "Ler é preciso" (www.ecofuturo.org.br), "Prazer em ler" (wwwwprazeremler.org.br) "Ler+ Família", do Plano Nacional de Leitura (em Portugal), o "Reach out and Read (nos Estados Unidos); "Nati per leggere" (Italia), "Bookstart” (Reino Unido). www.pln.org.pt
} 
A partir dessa perspectiva encontramos pesquisas que procuram investigar os primeiros movimentos de apropriação da escrita/leitura a partir da relação com o outro, fora do ambiente escolar (Dauden, 1994; Rojo, 1998; Mayrink-Sabinson, 1998). As autoras evidenciam que as práticas de letramento com crianças pequenas, pré-escolares, permitem à criança a apropriação de elementos da cultura letrada, independentemente do domínio da tecnologia do deciframento alfabético-ortográfico.

Bajard (2007) indica que a exposição da criança ainda não alfabetizada ou pouco letrada à leitura em voz alta de obras literárias, por um mediador competente, interfere positivamente no desenvolvimento do interesse pela leitura e escrita. Mesmo sem saber ler, as crianças têm acesso à literatura pelo caminho da escuta. (2007, p.15).

Também Brenman (2003) argumenta que a escuta de textos lidos possa levar a criança, no mínimo a uma aproximação aos livros e incidir positivamente no processo de formação de um leitor. (2003, p.104). O autor salienta que a criança que é exposta à leitura em voz alta pode perceber as diferenças na organização do escrito em relação ao oral e tem condições de enriquecer seu vocabulário. Brenman aponta ainda para a importância do desempenho da vocalidade no momento da leitura em voz alta: Talvez o desejo pela letra contida no livro venha a nascer, primeiramente, da voz de quem lê um livro infantil (2003, p. 123); mais adiante, na mesma obra, o autor intui que muitas vezes as lembranças das histórias ouvidas serão vagas, mas a memória do momento em que elas foram lidas em voz alta pelos professores, esta sim dificilmente será esquecida. (2003, p.146)

Portanto, não é novidade que a leitura em voz alta, sendo uma prática de letramento, provoque um efeito de inserção da criança no mundo das letras. ${ }^{6}$

\footnotetext{
${ }^{6}$ É necessário, contudo, relativizar tal proposição: a leitura que promove uma movimentação da criança em sua condição letrada é a leitura que convoca e que invoca. A leitura em voz alta que não permite ao leitor, ou àquele que escuta, uma participação no processo de construção de sentidos, pode criar um eterno escutador, passivo, a espera de um texto que virá sempre pronto, como descreve Bajard, 2005.
} 
O que sustenta esse efeito, de acordo com os autores citados, é o contato com formas linguísticas próprias da escrita, a partir do interesse mobilizado pelas narrativas, pelo apelo estético - linguístico e imagético - do livro infantil. O leitor, adulto, mediador de leitura $^{7}$, faz a ponte entre o texto e a criança. Sendo evento de letramento,mediação de leitura, a leitura em voz alta cria possibilidades de movimentação da criança em sua apropriação da escrita, como sugerem os trabalhos de Paiva e Rodrigues (2008), por exemplo.

Atraída pelo mundo da literatura graças às imagens e à voz do mediador, que confere vida às histórias adormecidas nos livros, talvez a criança chegue a desejar o poder de saber ler detido pelo adulto, afirma Bajard (2007,p.87). Mas, como a criança é atraída? Como a criança chega a desejar ter o poder de saber ler? Essas são questões que se impõem, e que pretendemos explorar no decorrer de nossa reflexão.

No presente trabalho, alinhamo-nos às observações acima, mas colocamos novas questões. É apenas o convívio com os textos escritos que faz a criança se movimentar em seu caminho de apropriação da escrita? A presencialidade daquele que lê é determinante para a atividade?

As cenas de leitura em voz alta que venho colecionando parecem indicar que tanto quem lê quanto quem escuta é afetado pela prática,- cenas em que a presença corporal dos atores é estruturante da atividade. Intuitivamente, poderíamos localizar algo de uma energia, que liga o leitor, o texto e aquele que escuta. Mas como teorizar essa "energia"?

A história me era familiar: minha mãe contava-a com freqüência, quando me levava, interrompendo-se para me friccionar com água de colônia, para apanhar debaixo da banheira o sabão que lhe escorregava das mãos, e eu ouvia distraidamente o relato bem conhecido; eu só tinha olhos para AnneMarie, a moça de todas as minhas manhãs; eu só tinha ouvidos para a sua voz perturbada pela servidão; eu me comprazia com suas frases inacabadas,

\footnotetext{
7 A noção de mediação, desenvolvida por diversos autores como Rojo (1998), Bajard (2007), é inspirada nos trabalhos de L. Vigotsky. Reintroduziremos a discussão sobre mediação e mediadores mais adiante, neste trabalho.
} 
com suas palavras sempre atrasadas, com sua brusca segurança, vivamente desfeita, e que descambava em derrota, para desaparecer em melodioso desfilamento e se recompor após um silêncio. A história era coisa que vinha por acréscimo: era o elo de seus solilóquios. Durante o tempo em que falava, ficávamos sós e clandestinos, longe dos homens, com outras corsas, as Fadas; eu não conseguia acreditar que se houvesse composto um livro a fim de incluir nele este episódio de nossa vida profana, que recendia a sabão e água-de-colônia. Sartre, J.P. As palavras, 1969, p. 30.

As palavras de Sartre evidenciam o desempenho daquele que lê e a intersubjetividade que se estabelece entre o texto, o leitor e a criança. A leitura em voz alta coloca o corpo em cena. E é justamente disso que trata o presente trabalho.

Aquele que lê toca o outro pelas orelhas; aquele que escuta é capturado pelos deslizamentos melódicos e rítmicos impressos na leitura. Também a criança que lê em voz alta lança-se ao outro e escuta o próprio corpo, já que a voz, conforme diz Zumthor (2007), é um corpo que se lança ao outro e retorna a si mesmo. Teria a relação de enlace pela voz fundamental na apropriação da fala e determinante na estruturação subjetiva, como afirmam Laznik (2000), Vorcaro (2001) e Jerusalinsky (2006) - efeitos específicos na apropriação da escrita pela criança?

Para uma aproximação à questão relativa ao que se passa quando alguém lê em voz alta para um outro, é necessário desemaranhar os fios que atam o leitor, o texto e aquele que escuta; procurar desvendar em que medida a experiência de alteridade e corporeidade vivida na leitura em voz alta, na evocação sonora que une língua e singularidade, impacta a criança no sentido da apropriação da linguagem escrita.

Tomando a leitura em voz alta como prática social e subjetivante e as possíveis implicações dessa prática no processo de apropriação da escrita pela criança, o presente trabalho - de natureza interdisciplinar - é tecido a partir do entrecruzamento de teorias e de práticas vividas ao longo de meu percurso profissional, como fonoaudióloga. 
Em que pese toda a mobilização determinada pela prática de leitura no presente trabalho, não se trata de uma pesquisa clínica. Minha intenção é articular elementos teóricos, nos campos da linguística, da psicanálise, da educação e da fonoaudiologia, ilustrando minhas reflexões com cenas advindas das práticas clínicas e não-clínicas.

"Teria a leitura em voz alta um lugar diferenciado no processo de apropriação de linguagem escrita pela criança?", eis a questão que orienta a pesquisa. Em nossa hipótese a resposta a essa pergunta é afirmativa: "Sim, a leitura em voz alta mobiliza práticas na relação corpo e linguagem que são específicas e que fazem eco nos processos de apropriação da escrita pela criança."

O presente estudo alinha-se às pesquisas de Belintane $(2006 ; 2007 ; 2008)$, que procuram articular aos processos de apropriação da escrita elementos específicos de jogos linguageiros da oralidade infantil, considerando que as marcas da constituição subjetiva recortam e costuram todo o tecido da linguagem.

Note-se que falamos em apropriação. A opção pelo termo não é casual. Trata-se de assumir uma posição não desenvolvimentista para investigar as relações entre a criança e o saber sobre a linguagem, como propõe Lemos (2002).

Reconhecendo a ineficácia das abordagens psicolinguísticas no campo da Aquisição da Linguagem para dar conta da complexidade da análise da fala da criança, abordagens que não conseguem lidar com a falta de regularidade dos processos descritos pela teoria, Lemos (2002) propõe considerar mudanças de posição em uma estrutura. Para escapar de uma visão desenvolvimentista, a autora encara a fala da criança como enigma, um desafio ao pesquisador, e sugere, a partir da leitura de Lacan, que a criança manifesta, em sua fala, três diferentes posições em relação ao outro. Tais posições não dizem respeito a etapas 
cronológicas, mas à constituição subjetiva, não havendo superação de uma ou outra posição. Aqui, sujeito é tomado na concepção psicanalítica, como efeito de linguagem.

Seguindo este pensamento, na primeira posição é possível encontrar uma alienação na fala do outro: a fala da criança aparece com marcas de fragmentação (em que as repetições de fragmentos da fala do outro são uma constante) e dependência (da interpretação do outro). Não há, no entanto, uma coincidência da fala do outro e da criança: analisando trechos de diálogos entre mãe e criança, Lemos (2002) chama a atenção para a escuta da fala da mãe na fala da criança. Poderíamos acrescentar que, embora retome fragmentos da fala do outro-como propõe a autora-, a fala da criança é endereçada, e a interpretação da mãe pode ser tanto "autorizada" quanto "interditada". Nesta direção que imprimimos a nossa leitura, entendemos que é justamente nesse endereçamento e autorização/interdição da interpretação do outro que emerge o sujeito.

Na segunda posição, não é a fragmentação ou a dependência que dá o tom, mas o aparecimento de erros, paralelismos e de interpretações idiossincráticas do funcionamento da língua. A língua é, continua Lemos, o pólo dominante, o sujeito está alienado no próprio movimento da língua.

Já na terceira posição, a criança reconhece a própria fala e o erro. Atua, então, para corrigir-se, ou nas palavras Lemos, são observados fenômenos como pausas, reformulações, correções, convocadas ou não pela reação direta ou indireta do interlocutor (2002, p.61) Nesta posição há uma criança que fala e que escuta sua própria produção e pode ler os efeitos de sua fala no outro. Embora Lemos não nos faça esta conclusão, sugerimos que nessa posição, a criança fala para um outro que é ao mesmo tempo semelhante e distinto de si, e sua fala é regulada pela língua sim, mas instanciada pelo outro, a quem a fala é endereçada.

Essa também é a opção de Belintane (2006; 2007; 2008), Calil (2007) e Lima (2007), que tratam especificamente da linguagem escrita. Para esses autores, a apropriação de 
formas linguísticas do escrito é um efeito da relação do sujeito com a língua e com o outro. Embora se aproxime dos estudos sociointeracionistas, ao considerar a relevância da interação nos processos de apropriação da linguagem (Dauden, 1994; Rojo, 1998; Mayrink-Sabinson, 1998, por exemplo), nossa perspectiva assume uma orientação teórica inspirada na psicanálise freudiana e lacaniana, que nos permite entender os processos de apropriação da linguagem como atrelados aos processos intrassubjetivos.

Para sustentar este posicionamento teórico é preciso, conforme comenta Belintane (2006, pp. 75-76), levar em conta a dimensão do inconsciente, a emergência subjetiva. Para o autor, aprender é movimentar uma subjetividade e não saltar entre estados de desenvolvimento.

Trabalhar com a articulação de aprendizado e emergência subjetiva implica interpelar a psicanálise no que esta torna possível pensar a questão. Como mostram Lajonquière (1999) e Kupfer (1999), considerar a emergência subjetiva nas questões do aprendizado e educação é poder olhar a criança em seu desejo - uma educação para o reconhecimento da realidade do desejo, como diz Lajonquière (1999, p.33), - e em sua singularidade, ambos produzidos no embate com o Outro.

Nesse sentido, a criança não domina sua escrita, mas é o efeito dela, comenta Kupfer (1999). Assim, o que está em jogo na apropriação da escrita é a operação significante, a subjetivação. É um exercício de letração, que as ordena, as reordena, a partir da interpretação do Outro. (1999, p. 23).

O objetivo principal deste estudo é argumentar a favor de uma perspectiva que considere a leitura em voz alta como prática mobilizadora da subjetividade - da dinâmica do desejo e da língua - e, portanto, atividade que interfere positivamente no processo de apropriação da escrita pela criança. Mirando tal objetivo, partiremos da articulação entre a 
literatura, a linguística e a psicanálise - que focaliza leitura, escrita, desejo e alteridade -, ilustrando o texto com figuras extraídas de vivências clínicas e não clínicas, para descrever um conceito, qual seja, o de corpo sonoro, que nos possibilitará articular subjetividade, lectoescritura e sonoridade, este último traço marcante da leitura em voz alta. A partir desse objetivo estabelecem-se outros, a saber: discutir de que forma se articulam os processos de estruturação do corpo sonoro no desenvolvimento da linguagem e na estruturação psíquica da criança e discutir as relações entre as vivências sonoro-corporais da criança e sua entrada na leitura e escrita.

Trata-se aqui de considerar a leitura como atividade criativa e prática discursiva. Afastamo-nos de uma concepção de leitura como simples transcrição de materialidades gráficas e fonêmicas, ou como atividade de remissão ao oral para extração do significado. Assumimos uma concepção de leitura em voz alta que é endereçada ao outro/Outro, dinamizando língua/corpo e sujeito.

O texto está organizado em cinco capítulos. No primeiro, discorremos sobre os conceitos de leitura em voz alta encontrados na literatura e a forma como tais conceitos articulam a discursividade e a corporeidade. Para tanto, fazemos inicialmente três considerações a respeito da leitura e da escrita: ler é uma prática discursiva, a leitura e a escrita envolvem processos indissociáveis e a leitura implica corpo. Em seguida, discutimos as implicações de trabalhar com a perspectiva de uma leitura encarnada, considerando a noção de corpo tal qual pensada a partir da psicanálise.

No segundo capítulo propomos algumas articulações possíveis entre a leitura em voz alta e a emergência subjetiva, abordando a leitura como lugar do Outro, as possíveis relações entre leitura e desejo, os atos de ler e de escutar. 
No terceiro capítulo abordaremos as relações entre leitura em voz alta e corpo sonoro, discutindo sobre a sonoridade na língua e no corpo e sobre o estatuto da voz no desenvolvimento da linguagem.

Finalmente, no quarto capítulo focalizamos a cena da leitura em voz alta, trazendo para discussão as relações entre corpo, língua e subjetividade, a partir do olhar, da voz e dos laços leitor/ouvinte-observador, para apresentarmos então no quinto capítulo nossas considerações finais. 


\section{Capitulo 1: A leitura em voz alta}

Anne-Marie fez-me sentar à sua frente, em sua cadeirinha; inclinou-se, baixou as pálpebras e adormeceu. Daquele rosto de estátua sai uma voz de gesso. Perdi a cabeça: quem estava contando? O quê? E a quem? Minha mãe ausentara-se: nenhum sorriso, nenhum sinal de conivência, eu estava no exílio. Além disso, eu não reconhecia sua linguagem. Onde é que arranjava aquela segurança? Ao cabo de um instante, compreendi: era o livro que falava. Dele saiam frases que me causavam medo: eram verdadeiras centopéias, formigavam de sílabas e letras, estiravam seus ditongos, faziam vibrar as consoantes duplas: cantantes, nasais, entrecortadas de pausas e suspiros, ricas em palavras desconhecidas, encantavam-se por si próprias e com seus meandros, sem se preocupar comigo: as vezes desapareciam antes que eu pudesse compreendê-las, outras vezes eu compreendia de antemão e elas continuavam a rolar nobremente para o seu fim sem me conceder a graça de uma vírgula. Sartre, J.P. As palavras, 1967, p. 31.

\subsection{Considerações iniciais a respeito da leitura e da escrita}

Sendo a leitura um conjunto de práticas difusas, como coloca Barthes (1987), seria mais adequado se falássemos em leituras. Portanto, antes de abordar propriamente as questões centrais a que este trabalho se dedica, faremos três considerações introdutórias a fim de colocar em foco nossa perspectiva.

Primeira consideração: ler é uma prática discursiva, um processo de produção de sentidos.

Dizer que a leitura é uma prática discursiva é localizá-la como uma das práticas linguageiras, é pensar a linguagem para além da língua, ou seja, na posição que o sujeito se coloca no uso da língua. Assim, remetemos o conceito de leitura a um ponto em que toma a 
linguagem em seu potencial expressivo estruturante e subjetivante, e não a encerra em um caráter utilitário, instrumental, meramente comunicativo (Kristeva, 1977; Orlandi, 2008).

Naturalmente a leitura envolve o domínio de um processo de decifração. Para se ler um texto é preciso, antes de tudo, decifrar o que está escrito, comenta Cagliari (2006, p. 62). Esse processo não busca encontrar a fala no escrito, mas articular oral e escrito em um sistema linguístico-discursivo (Cagliari, 2006; Marcuschi, 2007). Considerar a leitura um processo de produção de sentidos não implica delegar ao leitor um salvo-conduto na direção do texto. A língua, a cultura e as instâncias discursivo-enunciativas tratam de balizar o sentido.

Pensar a leitura desta forma implica delegar ao leitor certa autonomia em relação à recepção da escrita. Tratando-se de uma prática discursiva, linguageira, a leitura envolve uma subjetivação do texto. Na leitura não há uma mensagem a ser compreendida, dada a natureza polissêmica da linguagem, mas um texto a ser interpretado. Para Chartier (2001 p.78), é necessário dar à leitura o estatuto de prática criadora, inventiva, produtora, e não anulá-la ao texto lido, como se o sentido desejado pelo autor devesse se inscrever com toda a imediatez e transparência, sem resistência nem desvio, no espírito de seus leitores.

Nessa mesma direção, Goulemot (2001, p.108) afirma que ler é constituir e não reconstituir um sentido. O leitor não deve procurar o sentido desejado pelo autor, mas, a partir da articulação dos sentidos produzidos pelas sequências, dar um sentido de conjunto ao lido.

Trago aqui uma cena vivida na clínica. Priscila estava em atendimento fonoaudiológico em função de dificuldades na produção da escrita. A menina queixava-se de toda e qualquer atividade envolvendo a leitura ou a escrita; lidava de forma ansiosa frente ao material escrito, procurando desocupar-se logo da atividade. 
Durante uma sessão jogávamos "Escrevendo certo"8 - Em uma das rodadas, a garota dá uma resposta desconcertante. As questões propostas em sua ficha eram:

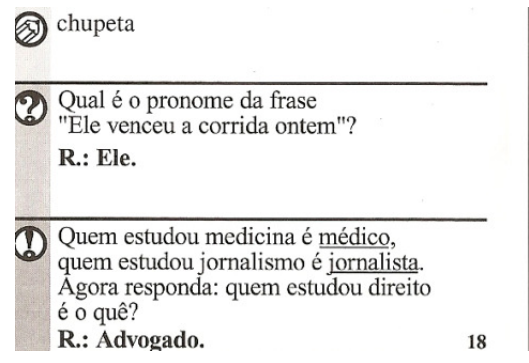

Figura1 - carta do jogo "Escrevendo certo"

Quem estudou medicina é o médico

Quem estudou jornalismo é o jornalista

Quem estudou direito é...

A resposta de Priscila

- ...é um bom aluno!

nos leva a perguntar “Alguém errou?" Certamente não foi a garota, mas aquele que imagina uma resposta certa para uma questão envolvendo uma palavra (direito) tão marcadamente polissêmica. A resposta de Priscila indica que, antes de evocar uma "dificuldade de leitura", o que está em jogo parece ser a apropriação de um horizonte discursivo marcadamente

\footnotetext{
8 Jogo da Grow, em que os jogadores devem percorrer uma trilha, movimentando seu pino à medida que respondem corretamente perguntas contidas em fichas. A trilha é composta de três signos que se repetem e revezam, determinando diferentes tarefas a serem realizadas pelo jogador. Se o pino cai sobre um pequeno lápis, o jogador deve escrever a palavra impressa na ficha após o símbolo "lápis", ditada por outro jogador; se o pino cai sobre um sinal de interrogação, o jogador deve responder à pergunta colocada na ficha, lida em voz alta por outro jogador; se o pino cai sobre o sinal de exclamação, o jogador deve completar frases ou responder a questões contidas na ficha, também lidas em voz alta por outro jogador.
} 
pedagógico. Não é uma questão de leitura, mas de saber supor o que deve ser lido; o leitor é colocado na posição de aluno, alienado à leitura escola.

Meu filho, aos sete anos, em uma das primeiras tarefas de casa, responde de maneira imprópria. A questão: Onde você mora? A resposta: na minha casa! O que meu filho descobrirá na escola é que, antes de responder, é preciso perguntar: O que se quer de mim? O que quer o Outro? Che vuoi? - é a pergunta, como observa Lacan (2008, p. 52), que orienta a relação com o outro, que articula desejo e alteridade.

É também o que está aprendendo Ana, aos seis anos. A menina frequenta o primeiro ano do ensino fundamental, está em processo de alfabetização, com algumas dificuldades, de acordo com a escola. Neste recorte, estávamos desenvolvendo uma atividade de responder "charadas". Após brincarmos um pouco na oralidade, passamos à escrita:

\author{
PERGUNTA 1: O QUE HÁ NO MEIO DO GOL? \\ RESPOSTA DE ANA: uma saída de energência, asa9 . \\ PERGUNTA 2: O QUE HÁ NO MEIO DA RUA? \\ RESPOSTA DO ADULTO: A letra " $U$ " \\ PERGUNTA 3: O QUE HÁ NO FIM DO TÚNEL \\ RESPOSTA DE ANA: A letra “ $L ”$.
}

Neste interessante recorte, percebemos que a criança faz sua leitura, observa a leitura do adulto, parece entender o que se quer dela e finalmente responde ao suposto esperado. O que está em jogo nesta cena é menos um aprendizado e mais um posicionamento subjetivo.

\footnotetext{
${ }^{9}$ Transcrição da fala da criança: emergência por "energência".
} 
A noção de uma "leitura correta" de uma única interpretação, de uma verdadeira compreensão, de um texto transparente, claro e direto, é produto de uma elite social, científica, pedagógica, eclesiástica, conforme De Certeau (1998 p. 261). Para o autor, a convicção de que o público é moldado pelo escrito (verbal ou icônico) e se deixa imprimir pelo texto permite vislumbrar uma imposição do texto, que organiza uma sociedade produzida por um sistema "escriturístico".

Esta impostura do texto, presente na concepção de uma única leitura correta, está associada ao que Berberian e De-Angelis (2006, p.15) identificam como violência simbólica nas práticas de leitura e escrita nos campos da educação e fonoaudiologia. Compartilhamos da posição das autoras, lembrando que muitas das práticas de leitura em voz alta nas instituições escolares e religiosas, prescritivas e normativas, apoiam-se na noção de leitura literal, de um texto impositivo, de uma leitura impostora.

À uma leitura inocente, passiva, opõe-se a noção de uma prática ativa, uma leitura crítica redimensionando o papel do leitor de receptor para co-autor. Os trabalhos da escola de Konstanz ${ }^{10}$, em especial a Teoria do Leitor Implícito (Iser, 1996) e das práticas da leitura, no modelo de Chartier et al. (2001), vão justamente nesta direção. Também para Jouve (2006, p.61), a leitura, longe de ser uma recepção passiva, apresenta-se como uma interação entre texto e leitor. É deste ponto que partimos para nossa segunda observação.

Segunda consideração: a leitura e a escrita envolvem processos indissociáveis.

Quem lê está ao mesmo tempo, e de certa forma, escrevendo.

Milton Hatoum, citado por Betty Mindlin, 2007.

\footnotetext{
${ }^{10}$ Também conhecida como teorias da Estética da Recepção, tendo Jauss um de seus mais importantes representantes.
} 
A primeira inscrição, o primeiro traço de escrita, lembra Manguel (2006), fez nascer ao mesmo tempo a escrita e o leitor. Leitura e escrita, embora mantenham especificidades como atividades, constituem um processo que é ao mesmo tempo simbólico, cultural e subjetivante.

Quem escreve, escreve porque alguém lê. A possibilidade da leitura está, para alguns autores, na motivação da escrita, o que implica uma anterioridade da leitura em relação à escrita: se faz traço porque ele pode ser reconhecido. Conforme Barthes \& Marty (1987, p. 32): (... ) o homem soube ler antes de saber escrever ou, querendo formular esta tese de uma maneira menos histórica, o acto de escrever tem origem no acto de ler (...)

Estamos aqui com uma questão delicada, cujo aprofundamento nos remeteria às controvérsias sobre a origem da escrita: a anterioridade da leitura é associada às leituras de rastros e pegadas de animais e marcas observadas na natureza (Barthes \& Marty, 1987; Rego, 2006). Ler a natureza não é o mesmo que ler uma escrita. Os mesmos autores também contraargumentam com a tese de que a escrita é anterior à leitura, segundo a perspectiva que considera que a escrita, visual por excelência, derivaria de uma gestualidade mimética, corporal, que depois passaria ao grafismo.

Embora a questão seja interessante, a discussão afastaria este texto de sua temática. Preferimos pensar, com Manguel (2006), em uma concomitância entre leitura e escrita. No entanto, parece ser possível afirmar uma anterioridade da "possibilidade de leitura": se eu posso ler traços, marcas, algum semelhante poderá também fazê-lo. ${ }^{11}$ Neste sentido a escrita comportaria um "depois do ato de escrever": a suposição da leitura.

Achei na praia um marisco

Com a letra do nome dela

Do lado eu fiz um rabisco

\footnotetext{
11 As noções de traço e semelhante serão abordadas em maior profundidade neste estudo nos capítulos posteriores. Aqui é importante registrar a presença do outro que lê na escrita.
} 
Botando a minha chancela

Ciranda Praieira

Lenine / Paulo César Pinheiro

Nestes versos de Lenine/ Paulo César Pinheiro, observamos o essencial da escrita: uma leitura singular, uma atribuição de sentido e um ato de fazer traço, de fazer marca.

O registro é sempre endereçado a alguém, mesmo que em algumas situações específicas, o leitor coincida com aquele que escreveu (como no caso de uma lista de compras, em que a escrita funciona especialmente como registro mnêmico). Da mesma forma, quem pratica a leitura, lê alguém. Ler e/ou escrever envolve, portanto, uma experiência de alteridade. Esta experiência é belamente ilustrada em Full of life de Walt Whitman( 1855), citado por Borges (1996):

Cheio de vida, hoje, compacto, visivel, $E$, com quarenta anos de idade no ano oitenta e três dos Estados. A ti, dentro de um século ou de muitos séculos, A ti que não nasceste, procuro,

Estás lendo-me. Agora o invisível sou eu, Agora és tu, compacto visivel, quem intui os versos e me procura, Pensando em como seria feliz se eu pudesse ser teu companheiro. Sê feliz como se eu estivesse contigo. (Não tenhas muita certeza de que não estou contigo).

O que podemos ver em Whitman é a dimensão transtemporal e intersubjetiva do escrito, que estabelece uma relação íntima entre aquele que escreve e quem o lê, fazendo do corpo do escrito o próprio corpo do escritor: escrever, neste sentido, é imortalizar-se.

Curiosamente, de maneira inversa, mas ainda mantendo o mesmo sentido de imaginar o escritor possível pelo leitor, Barthes (1988) afirma que o escritor vive um dilema: seu texto só existe na medida em que alguém o lê e, paradoxalmente, se lido, o texto é transformado, cria-se um novo texto pela interpretação do leitor. O que está em jogo aqui é a 
dimensão autoral que tem a leitura, na medida em que o sentido de um texto é dado no interjogo entre o autor e o leitor.

Assim se desvenda o ser total da escritura: um texto é feito de escrituras múltiplas, oriundas de várias culturas e que entram umas com as outras em diálogo, em paródia, em contestação; mas há um lugar onde essa multiplicidade se reúne, e esse lugar não é o autor, como se disse até o presente, é o leitor: o leitor é o espaço mesmo onde se inscrevem, sem que nenhuma se perca, todas as citações de que é feita uma escritura; a unidade do texto não está em sua origem, mas no seu destino. (Barthes, 1988, p. 70)

Também nesta direção encontramos Wolfgang Iser (1996). Para o autor a leitura é um processo de interação entre leitor e texto. Este processo é determinado por algumas condições de produção da escrita do texto, que comporta um leitor imaginado no texto. É esse leitor implícito que irá seguir, através de marcas interpretantes, os lugares vazios e as potências de negação. Estas duas instâncias, presentes no texto, irão organizar a interação leitor-texto, que determinará a recepção do texto e sua atualização como obra e como comunicação.

O autor marca a diferença entre a comunicação como se dá na interação diádica (face a face) e na escrita; na interação face a face os interlocutores podem negociar o sentido através de perguntas, comentários etc., o que não acontece na leitura. A relação entre leitor e texto carece de referências; estas serão dadas a partir da própria interação do leitor com o texto. A relação entre leitor e texto é, portanto, basicamente assimétrica, comportando uma carência de referências mútuas, que é a estimuladora para a interação produtiva de sentido.

A assimetria passa a ser dissolvida a partir da própria estrutura do texto que comporta lugares vazios, não-ditos que irão ser preenchidos com as interpretações do leitor. Estes lugares vazios não pedem uma interpretação complementar, mas uma interpretação que promove uma relação, uma combinação, entre as unidades do texto que não parecem bem conectadas. Ao longo do texto, novos lugares vazios reaparecem e provocam no leitor 
constantes rearranjos interpretativos, seja no foco, na tematização ou em outras conexões entre elementos do texto. De qualquer forma, o texto é um lugar em que o leitor age, e a atualização do texto é a própria atividade construtiva do leitor ${ }^{12}$. Assim, embora o leitor participe da construção do sentido, esta é em parte controlada pelo texto.

Se Iser introduz o conceito de leitor implícito, Eco (2002) localiza na leitura de textos narrativos, o leitor virtual, que atua colaborativamente na interpretação do texto. É possível reconhecer nos textos de ambos os autores, que há uma textualidade intencional; o leitor é imaginado. O modo como o sentido está construído no texto é o mesmo para todos os leitores, mas a relação com o sentido é singular. Cada leitor reage pessoalmente a percursos de leitura sugeridos pelo texto.

Seja o leitor implícito ou virtual, a atividade da leitura coloca em cena lugares hipoteticamente projetados. No entanto, outros teóricos se posicionam diferentemente. A noção de leitor Real, a partir dos trabalhos de Picard (1986) e Jouve (2002) encarna o leitor e coloca na cena de leitura outros elementos, encarnando a leitura. De maneira alternativa aos leitores desencarnados dos modelos de Eco e Iser, Jouve cria o Leitor Real que apreende o texto com sua inteligência, seus desejos, sua cultura, suas determinações sócio-históricas e seu inconsciente. (Jouve, 2002, p.15). No presente trabalho assumimos uma posição que considera o leitor uma instância imaginada, o que não nos obriga a descartar a corporeidade, história e subjetividade do leitor no ato da leitura. Assim, acreditamos ser possível concordar com Iser e com Eco, mas também com Jouve e Picard: considerar a instância de um leitor implícito ou virtual não implica desconsiderar a encarnação do leitor no ato de ler.

Tais afirmações nos levam imediatamente à

Terceira consideração: A leitura implica um corpo.

Foi como adquirir um sentido completamente novo, de tal forma que as coisas não consistiam mais apenas no que meus olhos podiam ver, meus ouvidos podiam ouvir, minha língua podia saborear, meu nariz podia

\footnotetext{
${ }^{12}$ Iser cita até mesmo Piaget, op.cit 157, para apropriar-se da noção construtiva do texto.
} 
cheirar e meus dedos podiam sentir, mas no que o meu corpo todo podia decifrar, traduzir, dar voz a, ler. Manguel, 2006, pp.18-19

O corpo das neurociências e da psicologia cognitiva, muito presente nas discussões sobre alfabetização, letramento e sobre os problemas da leitura e da escrita, é idêntico ao organismo. Trata-se de pensar a linguagem (oral e escrita) como comportamento, atividade ou função cortical (do córtex cerebral). Mesmo abandonando as posições estritamente localizacionistas de Broca e Wernicke (Luria, 1988), e pensando em redes neurais funcionalmente dinâmicas, o que as neurociências procuram é o substrato anátomofisiológico para a linguagem, para a leitura e escrita. Assim, de acordo com este pensamento, para podermos entender como funcionam a leitura e a escrita em nosso corpo, é preciso investigar as imagens da atividade cerebral e identificar os neurotransmissores envolvidos durante a atividade.

Diferentemente de outras posições cognitivas do passado, que opuseram o corpo à mente, a perspectiva monista das neurociências se ocupa em mapear anatômica e quimicamente aspectos que antes eram entendidos como psicológicos, separados do organismo, como as emoções e os afetos. Para Damásio (1996; 2000), o equívoco cartesiano foi defender uma perspectiva dualista centrada na razão. Poderíamos pensar que o erro de Damásio e das neurociências está em imaginar que só passa por nosso corpo aquilo que podemos identificar. $\mathrm{O}$ que se esquece é o fato de que a linguagem encerra as possibilidades de definir quais as emoções e os sentimentos que são reconhecidos e, portanto, mapeáveis.

Ora, muito antes de Damásio e das neurociências, foi o discurso freudiano que se contrapôs ao dualismo cartesiano. E, mais ainda, o que Freud ensina é que o que se diz sobre o corpo, se diz com palavras, sendo, portanto impossível dissociar corpo e linguagem. É a partir da psicanálise que se desenha um corpo que não é idêntico ao organismo, mas também não é separado dele. Neste sentido, o corpo é uma construção a partir de diferentes territórios, um artifício, não um dado imediato da natureza (Birman, 2003, p.14). 
Para Birman (2003), a partir da psicanálise, o corpo é construído a partir dos registros somático e orgânico, embora não se reduza a nenhum deles. Mas é a partir do outro que o corpo se ordena. Teríamos então dois pólos constitutivos do corporal: o organismo e o outro.

No presente trabalho, assumimos o conceito de corpo tal qual introduzido pela psicanálise: subjetivado, simbolicamente marcado a partir da relação com o outro, mas também matéria viva, pulsional e pulsante, encarnada. Colocamo-nos em oposição a uma neurociência ingênua, que não percebe as armadilhas da linguagem. Mas também rechaçamos uma perspectiva puramente mental ou social para a leitura. O que nos interessa aqui é pensar as relações entre corpo e leitura tal como pensadas por Barthes (1987), Birman (1996) e Milmann (2003).

Também tomamos Zumthor (2007, pp. 23-24), que, embora não faça referência explícita à psicanálise, elabora uma interessante maneira de abordar corpo e leitura:

O corpo é o peso sentido na experiência que faço dos textos. Meu corpo é a materialização daquilo que me é próprio, realidade vivida e que determina minha relação com o mundo. Dotado de uma significação incomparável, ele existe à imagem de meu ser; é ele que eu vivo, possuo e sou para o melhor e para o pior. (...) Eu me esforço menos para apreendê-lo do que para escutá-lo, no nível do texto, da percepção cotidiana, ao som de seus apetites, de suas penas e alegrias: contração e descontração dos músculos; tensões e relaxamentos internos, sensações de vazio, de pleno, de turgescência, mas também um ardor ou sua queda, o sentimento de uma ameaça ou, ao contrário, de segurança íntima, abertura ou dobra afetiva, opacidade ou transparência, alegria ou pena provindas de uma difusa representação de si próprio.

Além de valorizar a corporeidade do leitor, abordaremos também a corporeidade do escrito. A noção de suporte, introduzida por Chartier (2001) nos é útil por discriminar o escrito daquilo que o materializa. Esta noção nos permite entender que o suporte interfere no sentido do texto, do escrito, seja ele qual for. A mudança de suporte implica a mudança no sentido. Isto implica dizer que o escrito tem um corpo, uma matéria, que é constituída em parte pela organização discursiva e em parte por sua apresentação, seu suporte, sua forma. $\mathrm{Na}$ 
leitura jogam o corpo daquele que lê e o corpo do escrito, como testemunha Manguel (2006, p. 149):Minhas mãos, escolhendo um livro que quero levar para a cama ou para a mesa de leitura, para o trem ou para dar de presente, examina a forma tanto quanto o conteúdo.

Essa imagem, do corpo do leitor ao corpo do escrito, é preocupação de editores de livros e da mídia impressa em geral, como explica Chartier (2001): tornar o consumo confortável ao corpo ou então atrativo, valorizando o suporte em si mesmo, independente daquilo que carrega.

Voltando aos primórdios da escrita, (Havelock, 1996; Olson, 1997), podemos notar que as placas de cerâmica sumérias com as primeiras inscrições, que levam mensagens além do espaço e tempo imediatos, deveriam caber na palma da mão. Com a difusão da escrita, estas placas ficaram pesadas para um corpo carregar. Buscou-se material mais leve, transportável: o papiro e o pergaminho permitiam, então, escrever mais. Escrever mais, ler mais: o rolo (volumen) podia ser carregado e armazenado. No entanto, a leitura, mais intensiva, exige movimentos de retroação e progressão: o volumen não facilitava para o corpo do leitor. Aos poucos, o rolo vai sendo substituído pelo códice, que permitia uma leitura mais ergonômica.

A tecnologia da escrita está ligada às formas de ler, às habilidades cognitivointerpretativas do leitor, mas também se ocupa da adaptação do corpo à leitura. A imprensa de Gutenberg difundiu a escrita e ampliou o número de leitores e a intensidade da leitura, não por mudar radicalmente a escrita, mas por superar algumas limitações do corpo. Chartier (2001) lembra que os livros manuscritos e impressos eram estruturalmente muito parecidos. Gutenberg aliviou as dores dos escribas e dos copistas e criou um mecanismo que pode ir além do manuscrito. Produziu-se mais escrita, mais leitura. Criou-se todo tipo de material auxiliar à escrita e à leitura: mesas, cadeiras, camas, bibliotecas, salas, óculos. 
A relação do corpo com a leitura é dinâmica, atravessa os séculos e continua pulsante: temos computadores cada vez mais ergonômicos. Embora a discussão sobre como a leitura venha sendo transformada pelo uso dos e-books, da internet e mídias virtuais seja atual e ainda incipiente, não há dúvidas de que o corpo representa nesta discussão importante elemento. (Souza, 2007).

É possível perceber que as relações do corpo com a leitura apontam ainda para o estabelecimento de uma pedagogia leitora. Não é somente o suporte que deve se adaptar ao corpo, mas este também deve se conformar à leitura.

Somos um corpo leitor que cansa ou fica sonolento, que boceja, experimenta dores, formigamentos, sofre de cãibras. Há mesmo uma instituição do corpo que lê. Quando era criança, as senhoritas da escola privada onde fui educado nos falavam de uma atitude digna, respeitosa para ler, levemente apoiado sobre a mesa, as costas retas, sendo o relaxamento denunciado como uma forma de desprezo pela cultura. (Goulemot, 2001, p. 109)

Manguel (2006) lembra que São Bento determinava aos monges como seria a leitura: deviam segurar o livro com a mão esquerda, enrolada numa túnica e descansando sobre os joelhos; a mão direita devia ficar livre, para segurar e virar as páginas. Esta pedagogia leitora se transforma através dos séculos, adaptando-se aos usos e objetivos da educação e da leitura.

Também neste sentido, Faria Filho (2001) aponta para a escolarização de corpos que passa a acontecer nas escolas, com a racionalização das práticas pedagógicas, que buscam uma transformação da corporeidade da criança em corporeidade do aluno.

Além da relação física entre corpos, a leitura implica também uma relação simbólica do corpo com o escrito. Recortamos uma interessante passagem em Manguel (2006). Conforme o autor, na antiga sociedade judaica havia um interessante ritual de iniciação à leitura: a criança, no colo do professor, ouvia-o ler em voz alta e repetia as palavras. Após a cena, a criança deveria lamber a lousa em que estava o escrito coberto de 
mel, incorporando o escrito. Também versos bíblicos eram escritos em ovos cozidos descascados, e em tortas, os quais deveriam ser ingeridos, após a leitura em voz alta.

Essa ilustração da própria incorporação do escrito nos remete à idéia de que, para ter acesso à escrita, corpo, linguagem e alteridade devem estar presentes. Outra ilustração interessante é fornecida por uma prática, também associada à Igreja: o consumo de pílulas de Frei Galvão, no interior de São Paulo, em Guaratinguetá. Essa prática envolve também a incorporação do escrito, com a intermediação do outro. O fiel expressa seu desejo às religiosas, que o escrevem em papel, que é transformado em pílulas que são então ingeridas pelo fiel desejante. É preciso colocar a escrita para dentro do corpo, para que o escrito se torne vivo. Articulam-se aí desejo, escuta, escrita, corpo e outro, para que algo se movimente.

Também as crianças nos interrogam sobre a relação corpo/leitura/escrita. Trago aqui duas pequenas ilustrações que indicam a imagem de um corpo que está sendo marcado pela linguagem.

Aos quatro anos de idade, minha filha, Mariana, observava o irmão - então com seis anos - fazendo sua lição de casa; ele se contorce para "desenhar as letras cursivas"; ela também faz sua tentativa, atenta à corporeidade do irmão e finalmente se queixa, me dizendo algo como:

- Olha mãe! (mostrando sua escrita) eu tento, mas as letras não saem da minha mão!

Victor, aos sete anos de idade, em pleno processo de entrada formal na escrita, em uma sessão de atendimento em que jogávamos "Imagem e ação" "13, faz um desenho que "fala" não especificamente da leitura e da escrita, mas da relação entre corpo e língua. Ao

\footnotetext{
${ }^{13}$ Jogo da Grow em que os participantes devem adivinhar determinada palavra a partir do desenho que o outro faz.
} 
sortear uma cartela, escolhe representar por um desenho a palavra língua (uma das opções da cartela). Depois, escreve a palavra.

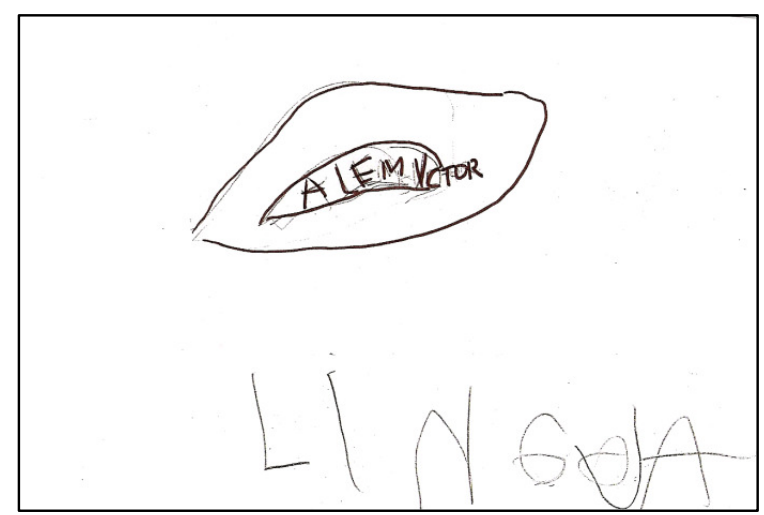

Figura 2: o desenho da língua

Em seu desenho, Victor representa o elemento anatômico - a língua - marcado pela língua-código, pelas letras, inclusive de seu nome; as letras estão inscritas no corpo, a língua, na língua.

Corpo e linguagem são indissociáveis (Burgarelli, 2003, Barthes,1974). No entanto, cansamos de constatar, em relação às crianças da escola atual, um diagnóstico excessivo de Transtornos de Déficit de Atenção e Hiperatividade e as falsas dislexias, resultado de uma apreensão da leitura como resposta orgânica, de um corpo dessimbolizado, ou de uma apreensão de leitura incorpórea, da qual só a mente se ocupa. Não há lugar para o corpo. Este se agita, escapa, procura seu lugar. A leitura incorpórea não evoca, não invoca. Sem desejo, nenhum movimento se faz em relação ao saber.

As três considerações aqui expostas tratam de identificar a leitura com a qual trabalharemos: prática discursiva, indissociável da escrita e suportada por um corpo. O efeito da linguagem no corpo, da leitura encarnada, remete ao sujeito. A seguir, examinaremos as implicações da voz na leitura para encaminharmos a reflexão sobre leitura e subjetividade. 


\subsection{Uma leitura encarnada}

Desde a Antigüidade, da voz alta à voz baixa e à extinção da voz, foi uma espécie de desencarnação da leitura que se operou uma redução da parte do corpo, uma ocultação do acto da leitura, do gesto: imóvel, silenciosa, solitária, já não tem existência carnal, é espiritual... Tal é o modelo cristão de leitura, sem fruição, uma leitura que não passa pelo corpo; do livro ao espírito, pela transparência do olhar, uma leitura limpa, sem contacto...

Para uma libertação do mito cristão da leitura, seria necessário começar por passar o texto pela "garganta", como fazia Flaubert, fazê-lo ressoar ecoar na cabeça. Continuar uma leitura do significante, a da fruição. Barthes, 1987, p. 194-195

De acordo com Chartier (2001), as modalidades ou estilos de leitura podem ser estabelecidos em função da intensidade da leitura (leitura intensiva ou extensiva), ou em função da sonorização do material lido, compondo então a leitura silenciosa e a leitura em voz alta.

As formas de ler, em voz alta ou silenciosa, são abordadas no relato de Santo Agostinho (sec. III) ao ver Santo Ambrósio ler silenciosamente. ... quando ele lia, os olhos divagavam pelas páginas e o coração penetrava-lhes o sentido, enquanto a voz e a língua descansavam (Agostinho, 1973, p. 111).

A forma tradicional de leitura até perto do século $\mathrm{X}$ era a leitura em voz alta. A leitura e a escrita sempre estiveram fortemente associadas a transações comerciais, mas também funcionaram como instrumento importante nas religiões, como forma de controle da doutrina e conduta dos fiéis. A palavra escrita, sagrada, só tem uma forma de ser interpretada: quem tem essa autoridade são os representantes oficiais da igreja, que lêem em voz alta para determinar o sentido e ensinar aos fiéis a leitura correta. Os fiéis por sua vez lêem em voz alta, exatamente como se deve, e não raro todo o corpo participa da leitura, com movimentos ritmados de tronco, por exemplo. O texto sagrado tem apenas uma interpretação e exige uma ritualização, um controle, uma estereotipia na passagem pelo corpo. 
É justamente o exemplo da leitura beneditina. Além das recomendações a respeito de como segurar o livro e manter o corpo durante a leitura - já mencionadas neste texto - no mosteiro fundado por São Bento, a prática da leitura em voz alta recebia destaque. A leitura beneditina era realizada em voz alta, exigindo-se total silêncio dos ouvintes; devia ser limpa, sem erros, e inquestionável, por se tratar da materialização da palavra divina "Senhor abre meus lábios e que minha boca manifeste teu louvor" (citado por Manguel, 2006). O texto era imutável e seu autor, divino, autoridade máxima.

O que parece determinante nessa prática é o controle sobre o corpo, com o propósito de exercer domínio sobre a interpretação do texto. Trata-se da interdição da participação ativa do leitor na construção do sentido.

A partir daí, o que parece ter mobilizado Santo Agostinho em relação à leitura silenciosa não foi a dessonorização da leitura, o repouso da língua em si, mas a possibilidade de acessar o texto sagrado individualmente, implicando uma espiritualização do ato de ler. Em "O Mestre" ${ }^{14}$ (2002), podemos identificar que, para Santo Agostinho, a relação direta com o divino, sem intermediários, era a base da espiritualidade.

Onde pensas que é oferecido o sacrifício de justiça, senão no templo da mente e nos aposentos do coração? Ora onde se deve sacrificar, aí se deve também orar. Por isso quando oramos, não é precisa a locução, isto é, as palavras sonantes; a não ser ocasionalmente, como fazem os sacerdotes a fim de exprimirem o seu pensamento, não para que os ouça Deus, mas os homens... (2002, p. 31)

Ora, acerca de todas as coisas que intelecionamos, não consultamos alguém que fala e produz um som fora de nós, mas a Verdade que preside interiormente à nossa mente, sendo talvez incitados pelas palavras a consultá-la. (2002, p. 99)

A leitura agostiniana, como diz Barthes (1973), diretamente do sagrado ao espírito, sem contaminação do corpo, provocou não somente mudanças na relação do corpo com o escrito, mas modificações no corpo do escrito. A passagem da prática usual de leitura em voz alta para a silenciosa ocupou séculos e exigiu uma constante e paulatina 
transformação da escrita. Como a leitura era tradicionalmente realizada oralizando o material gráfico, não havia espaço entre as palavras e os marcadores gramaticais e pontuação praticamente eram inexistentes (Bajard, 2005). A leitura consistia em transformação do escrito em fala; nas línguas antigas como o hebreu e o aramaico, ler e falar são expressos pela mesma palavra (Manguel, 2006).

Com o avanço da prática da leitura silenciosa, o sentido passa a ser construído individualmente, e não é mais impositivo que alguém leia em voz alta. A leitura perde um pouco de corpo. O escrito passa a ganhar corpo.

Com a finalidade de fornecer mais pistas para a interpretação do texto, começam a circular alguns elementos textuais que guiam a leitura como per cola et commata, sistema pelo qual o texto era dividido em linhas de significado. Aparecem prólogos nos textos, situando a leitura. Em seguida surgem combinações de traços e pontos par dirigir as pausas e a formação de sentidos. No séc. IX os escribas passam a regularmente separar as palavras, até que na Irlanda é desenvolvido o sistema de pontuação que utilizamos até hoje. Da mesma forma, para facilitar a leitura e incentivar o leitor, no séc. $\mathrm{X}$ o início de textos era escrito em letra maior; depois, apenas a primeira letra, o que deu origem ao uso das maiúsculas (Bajard, 2005).

Também depois da invenção de Gutenberg, com o aumento da quantidade de material disponível e a leitura mais fluente, outras marcas foram modificando o corpo do escrito, como é o caso de Francesco Griffo (citado por Manguel, 2006), o italiano que desenvolveu um artifício para que determinado trecho importante do texto fosse lido mais lentamente: criou letras grafadas de forma inclinada, dificultando a visualização e promovendo uma leitura lentificada e mais atenta. É o que conhecemos como itálico, e

\footnotetext{
${ }^{14}$ De Magistro, original em latim.
} 
também de onde vem a prática de grifar um segmento de texto, que deve ser lido mais atentamente.

O desenvolvimento da leitura silenciosa representou também - e talvez principalmente - modificações na relação entre texto e leitor. Esta modalidade de leitura permite interpretações variadas. Se a tradição da Igreja católica sustentava que as escrituras deviam permanecer um mistério, somente revelado pelas autoridades eclesiásticas, os heréticos e protestantes sustentavam que as pessoas tinham o direito de ler a palavra de Deus em si mesma, sem testemunhos intermediários.

A leitura em voz alta foi, e ainda é, ao lado da recitação (memorização e oralização do texto), utilizada como instrumento de controle do sentido e da decifração, recurso de instituições totalitárias. Mas há outros usos e desdobramentos da leitura em voz alta, como veremos a seguir.

Para além das práticas religiosas, apresentavam-se práticas de leitura em voz alta na Idade Média, estimuladas pela escassez e alto custo de livros e pela condição rara da alfabetização. Ter acesso a textos ligava-se bastante, portanto, à possibilidade de ouvir alguém lendo. As leituras públicas eram comuns na corte, na nobreza: o trovadorismo, encenando o amor cortês, foi popular especialmente na Europa latina, conforme Barros (2008). A figura dos jograis - artistas, muitas vezes simples, e inclusive mulheres, que se apresentavam em mercados e feiras livres -, foi se instituindo, sendo muitas vezes mais popular que a dos trovadores, tidos como mais eruditos. Os jograis ora liam, ora recitavam obras de autoria própria ou de outrem. Tal atividade literária mesclava a poesia oral e a leitura em voz alta. Zumthor (2007) considera a corporeidade envolvida na poesia oral medieval um fator determinante para sua popularização e penetração em diferentes esferas sociais. No entanto, mesmo sendo ambas as práticas discursivas marcadamente 
performáticas, a leitura em voz alta não se confunde com a poesia oral, nem com a contação de histórias, popular na atualidade.

Na contação de histórias o foco é a narrativa; na leitura em voz alta o foco é a escrita. Ao contar histórias, o contador pode utilizar diferentes recursos cênicos: trata-se de uma atividade que se aproxima do teatro. Ao ler em voz alta o leitor utiliza sua voz. Na contação de histórias o texto original pode ser adaptado, modificado e a presença do material gráfico não é determinante. Quem lê em voz alta deve ser fiel ao texto escrito. Ler e recitar são práticas diferentes, conforme Brenman (2003) e Pastorello (2007).

O poeta oral apresenta um texto estruturado e organizado como uma escrita, mas sem o apelo visual. Nos relatos de Abreu (1997), sobre a poesia oral no Brasil, aparece a figura de um poeta cego, que para vender suas poesias finge ler; muitos dos cordelistas são analfabetos, mas têm seus textos escritos por um escriba: estabelece-se uma relação particular com o escrito: o poeta oral faz de seu corpo o suporte do escrito, que é bem diferente do que faz o contador de histórias.

Alguns séculos depois das práticas trovadorescas da Idade Média, outra prática envolvendo a leitura em voz alta chama a atenção: os leitores públicos de Cuba. Em 1865, sendo Cuba ainda controlada pela Espanha, Saturnino Martinez - poeta e charuteiro - criou um jornal destinado aos trabalhadores da indústria de charutos, La Aurora, que se propunha a organizar politicamente a atividade dos trabalhadores e também a levar até eles produções literárias, conforme descreve Manguel (2006). Em função do analfabetismo, Martinez sente dificuldades para atingir os trabalhadores; institui, então, a prática da Leitura Pública. Um leitor - escolhido entre os operários - lia os textos em voz alta para os trabalhadores durante os turnos regulares. A princípio lia-se La Aurora, mas aos poucos passaram a ser lidos poemas, romances, contos, sempre escolhidos pelos trabalhadores. 
El Fígaro foi a primeira fábrica a iniciar as Leituras Públicas, que ganharam fama e popularidade, até que foram consideradas subversivas e proibidas em 1866. Tempos depois, imigrantes cubanos nos Estados Unidos (Flórida) levaram consigo esta prática leitora, que permaneceram ativas nas fábricas de charutos até cerca de 1920. Alexandre Dumas era um dos autores preferidos, tendo cedido seu sobrenome a um charuto, a pedido de operários.

Muitas questões podem ser colocadas a partir desta interessante prática discursiva. Embora aqui não nos proponhamos a explorá-las, vale apontá-las, como possibilidades investigativas. Manguel (2006) já anuncia algumas questões:

Ouvir alguém lendo para eles, descobriram os charuteiros, permitia-lhes revestir a atividade de enrolar as folhas escuras do tabaco - atividade mecânica e entorpecedora da mente - com aventuras a seguir, idéias a levar em consideração, reflexões das quais se apropriar. Não sabemos se, durante as longas horas na fábrica, lamentavam que o resto de seus corpos não participasse do ritual de leitura; não sabemos se os dedos daqueles que sabiam ler ansiavam por virar uma página, por seguir uma linha; não sabemos se aqueles que nunca haviam aprendido eram estimulados a fazêlo. (Manguel, 2006, p. 136)

Mais ainda, podemos questionar quais implicações, subjetivas e culturais, envolvidas na atividade de Leitura Pública em Cuba fizeram que fosse censurada e então levada ao exílio? Seria apenas a natureza dos textos lidos? Teriam a forma de ler, a presencialidade, as entonações e interpretações do leitor, alguma relação com o desenrolar dos fatos? As cenas de leitura se limitavam à leitura do texto?

A partir das ilustrações apresentadas, é possível perceber que não á a modalidade em si (em voz alta ou silenciosa) que determina a função e efeitos da leitura, mas sim a relação do leitor com o texto, ou seja, como é determinada a produção do sentido. Conforme observa Birman (1996, p. 53), as leituras em voz alta realizadas na Antiguidade não tinham o mesmo significado que a leitura silenciosa dos monastérios ou que as leituras em voz alta realizadas comumente no ambiente familiar nos séculos XVII e XVIII. 
Embora represente uma modalidade de leitura - que, como vimos, pode estar ligada a diferentes perspectivas sociais e culturais - , a leitura em voz alta atualmente parece estar recoberta de negatividade. A prática da leitura em voz alta é vista com restrições. Ao que parece, estas restrições estão relacionadas a três fatores: primeiramente, ao conceito de leitura que se adota; em segundo lugar, a uma perspectiva de superioridade da cultura escrita em oposição à oral; finalmente, a uma perspectiva ingênua de opor leitura em voz alta e leitura silenciosa, procurando estabelecer entre elas hierarquia e valores, desconsiderando uma abordagem que coloca ambas as atividades como modalidades possíveis de leitura.

Bajard (2004) traz dados de Instruções Oficiais francesas para o ensino da leitura, que ressoam na realidade da escola brasileira. Segundo o autor, desde a publicação das normas para a aprendizagem da leitura, em 1923 até os anos setenta, aprender a ler implicava três momentos: a decifração - conversão de sinais gráficos em fonemas - que deve ser realizada através da leitura em voz alta, a leitura corrente - mais fluida, quando começa a aparecer o sentido do texto lido e a leitura expressiva, que implica o domínio do significado do texto. Estas etapas eram necessariamente realizadas com a leitura em voz alta, pois o professor deveria controlar o desempenho do aluno. A leitura em voz alta aqui é exatamente uma forma de controle sobre o corpo, de normatização. A perspectiva de apenas uma leitura correta nos lembra as leituras ritualísticas religiosas. Mas há algo mais, implícito nesta perspectiva: a compreensão do texto é dada pela leitura em voz alta, pela sonorização, ou oralização. O texto escrito aqui é simulacro codificado da fala.

Esta noção, de que a escrita é transcrição do oral, marca a primazia da sonoridade no trato com a escrita. Embora os trabalhos de Foucambert (1994) - introduzindo na cena a leitura ideovisual - tenham em parte desarticulado a perspectiva do fonocentrismo, é possível reconhecê-la nos trabalhos atuais da psicologia cognitiva e das neurociências, em que a leitura em voz alta é usada como recurso de reorganização da consciência fonológica. 
De qualquer forma, é justamente a partir da noção de leitura ideovisual - que vem se contrapor ao modelo fonocêntrico de leitura e aprendizado - que a leitura em voz alta perde o lugar central que lhe fora dado, e passa a ser vista como uma técnica difícil, que nem todas as crianças irão dominar, conforme exposto no Discurs sur la lecture (Chartier e Hébrard, 1989). Subjacente ao uso/desuso de leitura em voz alta na escola, o que está em jogo não é propriamente a modalidade, mas a perspectiva que se tem de escrita, sua relação com a oralidade. De fundamental e central, a oralização do escrito passa a ser desnecessária e até problemática.

Para Kleiman (1993), a crise atual de leitura e da escrita na escola - e também fora dela - pode ter suas raízes nas concepções equivocadas de leitura, de texto e de linguagem que se tem adotado na escola. A autora identifica que a atividade árida e tortuosa da decifração, que é chamada de leitura na sala de aula, nenhuma relação tem com a atividade discursiva de composição do sentido. Ninguém gosta de fazer aquilo que é difícil demais, nem aquilo do qual não consegue extrair sentido, comenta a autora (1993, p. 16).

A formação de um pseudoleitor - passivo na produção do sentido - que se observa na atualidade, é para Kleiman, reflexo de uma prática pedagógica que trata a leitura como atividade de decodificação, como prática de avaliação de capacidades linguísticas e cognitivas, levando a uma concepção autoritária de leitura, que impõe um sentido verdadeiro e único ao texto, que deve ser alcançado por todos os leitores.

É possível associar tais práticas àquilo que De Certeau (1998) chamou de impostura do texto, que revela, mais do que opções metodológicas ou teóricas sobre a leitura, a atividade de um sistema escriturístico controlado para que o leitor se deixe imprimir pelo texto, para que o leitor se molde às exigências político-sociais, científicas, econômicas, religiosas e pedagógicas circulantes. 
Lembramos aqui o trabalho de Eco e Bonazzi (1980), Mentiras que parecem verdades, em que os autores investigam práticas pedagógicas no trabalho de leitura e interpretação nas escolas, durante o regime fascista italiano. Os autores identificam como os textos escolares eram construídos com a finalidade da transmissão ideológica, de conceitos morais e éticos que interessavam ao poder político dominante. Mesarani (1980), na apresentação da edição brasileira, associa tais práticas ocorridas na Itália às práticas observadas no Brasil, especialmente durante os anos do regime militar, quando a preocupação era criar e suportar a imagem do Brasil varonil, ao mesmo tempo submisso ao lema "ame-o ou deixe-o". Mas será possível identificar tais práticas a apenas alguns momentos sócio-históricos? Será que, na atualidade, a escola e as práticas educacionais não estão mais a serviço de suas agências de manutenção? No momento em que se interfere até mesmo nos textos da tradição oral (como Atirei o pau no gato), para torná-los politicamente corretos, que tipo de leitura, de texto e de produção do sentido podemos ver circular? São questões que certamente não daremos conta de abordar na profundidade que merecem, mas que podem ajudar a localizar de onde vem a desvalorização da leitura em voz alta: da impostura do texto.

A leitura em voz alta tem sido utilizada sistematicamente nos processos de impostura do texto, e assim, de alguma forma, criou-se a imagem equivocada de que a prática de dar voz ao escrito estava em si mesma associada ao controle, à avaliação, ao autoritarismo.

É possível perceber a partir daí uma espécie de revanche contra a sonoridade e a oralização, um quase esquecimento de que há uma inscrição do oral no escrito, como observam Marcuschi (2007) e Belintane (2008). Aqui se impõe uma breve reflexão sobre as relações que se estabelecem entre a oralidade e a escrita.

O interesse pela discussão da relação entre o oral e o escrito remonta ao século XVIII, conforme comenta Havelock (1996), embora as relações de tensão entre sociedades 
orais e letradas existam praticamente desde o nascimento da escrita. No entanto, a partir dos anos 1950, com os trabalhos de McLuhan, (in Havelock, 1996), Ong (1982) e Olson (1997) e do próprio Eric Havelock (1996), as especulações sobre os impactos da textualidade - ou do letramento - sobre a organização social, política, econômica e cultural das sociedades, e sobre as implicações cognitivas da escrita na humanidade, provocaram uma noção de oposição e de hierarquia entre o oral e o escrito.

Esta posição - bastante freqüente nos textos das décadas entre 1950 e 1980 e criticada por Marcuschi (2006) - defendia uma independência da escrita em relação ao oral e uma organização qualitativamente superior, cognitiva e linguística, dos indivíduos que dominavam a leitura e a escrita.

Desta apreensão dicotômica do oral/escrito, decorre a noção de que as sociedades letradas seriam superiores, ou mais evoluídas do que as sociedades de oralidade primária. Para Marcuschi (2006), esta é uma posição ideológica, e não histórica. A noção de progresso está de tal modo associado à alfabetização, que esta teria um valor intrínseco, desejável ao indivíduo. Mesmo que seja claro que vivemos tempos diferentes da Idade Média, não deixa de ser falacioso usar isso como argumento a favor da supremacia da escrita (2006, pp. 23-24).

Mesmo argumentando a favor de uma modificação social e cultural a partir do surgimento da escrita na Grécia Antiga, Havelock (1996) indica perigos em generalizar o caso grego para qualquer reflexão sobre a relação oralidade/letramento, equação nada simples, conforme o autor.

A presunção genérica é a de que as civilizações, para merecerem o nome, têm de se basear nalgum tipo de escrita, têm de ser nalgum grau, letradas. Provavelmente, a maioria dos especialistas que se ocuparam destes assuntos, incluindo os classicistas, ainda partilham esta visão. É certamente verdade para os leigos. (Havelock, 1996, p.,73) 
O autor lembra que algumas culturas avançadas, como a dos Incas, do Peru - as quais foram totalmente não letradas, mas se constituíram em uma sociedade civilizada, com arte, arquitetura e instituições políticas próprias - fazem ultrapassar a necessária associação civilização/escrita.

Barthes \& Marty (1987) são categóricos ao tratar da suposta associação entre escrita / racionalidade: revisitando a história da escrita, os autores salientam que a característica da escrita por excelência é visual; a escrita alfabética, o foneticismo representam um período, atual, da escrita. Evocando o racionalismo aristotélico e a mística da cabala, fenômeno da escrita, os autores apontam para a impossibilidade de separar oral/escrito como se separa mito e racionalidade. Para os autores, dizer que as sociedades sem escritas e os analfabetos estão do lado do mito e que a escrita é a via da racionalidade é restringir seriamente a palavra e a escrita (...) ( p. 53).

Abandonando a dicotomia entre oral e escrito, quer de práticas sociais, quer de fenômenos linguísticos produzidos, Marcuschi (2006) propõe pensar em uma relação de continuidade - um "continuum" - oral-escrito, sem avaliação qualitativa, mas de múltiplas interferências entre as realizações enunciativas da mesma língua. Para o autor, que redimensiona o termo, letramento não diz respeito às práticas envolvendo as formas linguísticas do escrito, mas uma prática social estritamente relacionada a situações de poder e etnograficamente situada (2006, p. 47).

Considerando da mesma forma as relações de continuidade entre o oral e o escrito, Tfouni (2006) sugere que a noção de autoria possa ser utilizada para fundamentar o processo de letramento e relacioná-lo com o continuum oral-escrito. Nesta perspectiva, a autoria diz respeito a uma posição do sujeito frente à língua, em que se faz aparecer o traço singular, a autoria de um texto, pelas manipulações de significados estabilizados e a criação 
de transformações de sentido. Assim, tanto mais letrado é o sujeito quanto mais autor - de textos orais e/ou escritos - ele for.

Percebemos assim um afastamento da noção de letramento da textura gráfica ou visual da escrita. É interessante aqui marcarmos a diferença entre a escrita e o escrito. Aquilo que é visível, gráfico, este é o escrito. A escrita remete ao processo, ao conjunto de gestos e atos que denotam uma maneira de tratar a língua (Barthes e Marty, 1987), uma forma específica de enunciação (Bräkling e Belintane, 2002, Barthes e Mauriès, 1987, Rojo, 2006).

Nesta direção, Corrêa (2006), inspirado pela análise do discurso francesa ${ }^{15}$, sistematiza a noção de letramento propondo dois sentidos para o termo: letramento sentido restrito e sentido amplo. Por letramento sentido restrito entende-se a condição do indivíduo que exerce, direta ou indiretamente, práticas de leitura e escrita (2006, p. 137). No sentido amplo, o letramento refere-se ao caráter escritural de certas práticas, presente mesmo em comunidades classificadas como de oralidade primária. (loc.cit.). $\mathrm{O}$ autor esclarece que neste sentido a escrita transborda a dimensão gráfica e passa a se configurar como um modo de enunciação, constitutivamente heterogêneo, que envolve a manipulação de elementos sistematizados e normatizados e que apresenta um caráter de permanência no tempo. Esse tipo de registro que aparece nas práticas orais apresenta um caráter de permanência no tempo semelhante ao que normalmente se atribui à escrita (loc.cit.).

Corrêa (2006) indica que há, em certas práticas orais, um grau de permanência no tempo que independe da tecnologia da escrita alfabética. A proposta do autor é valorizar certas habilidades na oralidade que fazem registro da língua e da memória cultural. A escrita como enunciação está distante da escrita como materialidade gráfica.

A escrita que se opera na oralidade é também apresentada por Belintane:

A aliteração, a assonância, as rimas, os paralelismos sintáticos e outros recursos já constituem um conjunto de recursos de escrituração, que podem

\footnotetext{
${ }^{15}$ A partir de Pêcheux (1990) e Orlandi, (1996).
} 
funcionar inconscientemente (nos chistes, lapsos, associações inusitadas, nos sonhos etc,) ou conscientemente a partir do domínio de algum jogo, de alguma brincadeira. (2006, p. 79)

Percebe-se que o que está em jogo aqui não tem a dimensão do oral/não oral, mas a da escrita como manipulação de recursos da língua. Belintane (2006) fala em sonoridade, não tomada em sua materialidade, mas como traço. Estamos aqui bastante distantes da dicotomia oral/escrito e demasiadamente longe de pensar a escrita como transcrição da matéria sonora. Pensar a escrita como um gesto de imprimir traços é aproximar-se do que Freud chamou de escrita psíquica, cujo escrito não é legível, mas reconhecível, conforme comenta Rego, 2006.

Embora reconheçamos esta dimensão da escrita, no presente trabalho chamaremos de escrita uma prática específica de enunciação, que envolve gestos de imprimir traços, um movimento em direção à estabilização destes traços, movmento que afeta tanto o conteúdo quanto a forma estética do texto. Utilizaremos o termo escrita psíquica para tratar o que, a partir da psicanálise, evidencia o funcionamento de uma máquina de escrever: o inconsciente. Finalmente, reservamos o termo escrito para referirmos o visível, o material, o que se pode ver a partir da operação de escrita.

O que é legível é o escrito. Ele é lido com o corpo e com a mente. Na fronteira entre o somático e o psíquico não é possível falar em corpo, leitura e subjetividade sem relevar as pulsões. Nos capítulos seguintes examinaremos mais detalhadamente o olhar e a voz e como se organiza a cena de leitura em voz alta, escópica e invocantemente.

Adotamos no presente trabalho o termo leitura em voz alta e consideramos, como sugere Babo (1996), que a escuta de textos é uma modalidade de leitura. Brenman (2003) optou por utilizar "leitura em voz alta" em sua dissertação de mestrado por conta da popularidade do termo. 
Nossa opção, contudo, não se deve apenas à popularidade do termo, mas também à evidência do corpo implicada na palavra voz. O que interessa aqui é a valorização da vocalidade e da performance, seguindo as expressões de Zumthor (2007, p. 27).: Considero, com efeito, a voz, não somente nela mesma, mas (ainda mais) em sua qualidade de emanação do corpo e que, sonoramente, o representa de forma plena.

Com suas raízes no latim (Cunha, A G., 1982), a palavra voz remete a vocativo, chamado. Mário de Andrade incrementa o sentido que voz pode alcançar: Esta palavra (voz) tinha muitos sentidos usados na terminologia jurídica. Significava: direito, pessoa, vida, geração (1989, p. 567). Voz remete de certa forma ao chamado, à vida. Assim, o termo "leitura em voz alta" faz aparecer o corpo.

Julieta Jerusalinsky (2006), retomando a etimologia de voz, chama a atenção para a distinção entre vox e phoné: Enquanto o termo phone, do grego, do qual se derivam fonação, afonia, disfonia, cacofonia, refere-se especificamente à produção do som, o termo voz implica que a produção sonora seja tomada como chamado (2006, p.208 ).

Neste sentido, ler em voz alta está além de sonorizar o texto: revela um chamado. Quem é chamado? É a questão que examinaremos a seguir. 


\section{Capítulo 2: Leitura em voz alta e produção de subjetividade}

\begin{abstract}
Quanto à história, endomingara-se: o lenhador, a lenhadora e suas filhas, a fada, todas essas criaturinhas, nossos semelhantes, tinham adquirido majestade, falava-se de seus farrapos, com magnificência; as palavras largavam a sua cor sobre as coisas, transformando as ações em ritos e os acontecimentos em cerimônias. Alguém se pôs a fazer perguntas: o editor do meu avô, especializado na publicação de obras escolares, não perdia ocasião de exercitar a jovem inteligência de seus leitores. Pareceu-me que uma criança era interrogada: no lugar do lenhador o que faria? Qual das duas irmãs preferiria? Por quê? Aprovava o castigo de Babette? Mas essa criança não era absolutamente eu, e fiquei com medo de responder. Respondi, no entanto: minha débil voz perdeu-se e senti tornar-me outro. Anne-Marie, também, era outra, com seu ar de cega superlúcida: pareciame que era filho de todas as mães, que ela era mãe de todos os filhos.
\end{abstract}

As Palavras, J.P. Sartre, 1969, p. 31

A leitura, e mais evidentemente a leitura em voz alta, implica o corpo. Mas, sendo uma prática discursiva, é circunscrita pela língua. Na leitura, circula uma lei-dura, conforme afirma Belintane (2007). Essa lei dura, instanciada pela língua, produz, no corpo leitor, interditos. Esta função de corte da língua é bem ilustrada por um lamento de Kafka: Ontem me ocorreu que, se nem sempre amei minha mãe tanto quanto ela merecia e quanto sou capaz de amar, foi a língua alemã que me impediu de fazê-lo (Pawel, E. 1986,p. 242).

Aqui começamos a desemaranhar os fios que atam leitor, corpo, língua e texto: ler, sendo prática discursiva, carrega um traço de escrita, no trato com o escrito.

\subsection{A leitura como lugar do Outro}

- Você tem um outro por dentro...

Foi sua mãe quem lhe disse, pela primeira vez, a frase assustadora. Outra pessoa dentro do seu corpo. E agora essa! Como se não bastassem todos os seus terrores. $O$ escuro. A certeza de que tinha um monstro embaixo da cama. Banho. Matemática. Leite de magnésia. Roque, o colega de aula maior do que ele, que vivia ameaçando lhe bater. Outro por dentro!

Luis Fernando Veríssimo - O analista de Bagé, 1982. 
Freud (1980), em Psicopatologia da vida cotidiana, aponta para os lapsos na leitura, índices de sujeito. Para o autor, os erros na leitura - lapsus calami - são da mesma ordem dos lapsos e chistes na fala: brechas onde o sujeito se insinua, em que se deixa vislumbrar a alteridade constitutiva.

Assim como na oralidade, o que determina o erro na leitura como uma "não eventualidade" é a resposta, o comparecimento do corpo e do afeto ao se deparar com o erro: enrubescimento, vergonha, irritação. Freud, comentando sobre seus próprios lapsos de leitura, observa:

Irritante e ridículo é um lapso de leitura que tendo a cometer sempre que, em minhas férias, ando pelas ruas de alguma cidade desconhecida. Nessas ocasiões, leio como "Antigüidades" todos os letreiros de loja que de algum modo se assemelham a essa palavra. Nisso se manifesta o gosto do colecionador pela aventura. ${ }^{16}$

Freud recolhe casos de lapsos de leitura e organiza uma breve tipologia. Em alguns casos (a maioria), há uma predisposição do leitor que altera a leitura e introduz no texto algo que corresponde a suas expectativas ou que o está ocupando. Nestes casos o texto apenas oferece alguma semelhança sobre a qual age o leitor. Em outros casos, há uma maior participação do texto no lapso, de modo que ele contém algo que mexe com as defesas do leitor - alguma comunicação ou exigência que lhe é penosa - e que, por isso mesmo, é corrigida pelo lapso de leitura, no sentido de um repúdio ou uma realização de desejo.(Freud, 1901, Sobre a psicopatologia da vida cotidiana, cap. VI)

O que se lê é o escrito: marcas de uma operação significante. Há algo que atrai o olhar: não podemos evitar ler as legendas em português em um filme dublado. Para aquele que domina a técnica da decifração, deparar-se com o escrito e não ler é aflitivo, quase impossível.

\footnotetext{
${ }^{16}$ As citações de Freud são da edição eletrônica. Ver referâncias.
} 
Leio uma camiseta em que está escrito "Atenção, não leia esta camiseta”. Esta brincadeira faz pensar que há no escrito um grito mudo para ser lido. Algo como a latinha brilhante, boiando ao sol na superfície das ondas: ela me olha\{...\} tem algo a ver comigo, diz Lacan no seminário XI (1990, p. 94), ao referir-se à pulsão escópica. O texto escrito se dá a ler com todo seu corpo visível, se mostra, se insinua.

Contudo, ao depor o olhar sobre o texto não são apenas as letras que vemos: o conjunto visível de traços, espaços, diferenças de tamanhos, grafias, pontos, vírgulas, linhas, imagens verbais e não verbais compõe o visível. É isso que é olhado: uma oferta de marcas que orientam /desorientam a leitura. Podemos pensar o lapso da leitura como o instante fugaz em que as marcas visíveis do escrito olham o leitor; neste instante em que o inconsciente, instância entre a percepção e a consciência (Freud, 1895/1981) faz marcas na leitura a partir de mecanismos metafóricos e metonímicos: errar a leitura faz emergir o sujeito.

Quando Freud afirma que há uma participação do texto no lapso, entramos na dimensão do olhar. O escrito em sua materialidade gráfica comporta os traços grafados da língua, mas também revela restos e traços de significantes não visíveis, testemunhos daquilo que Freud chamou de escrita psíquica.

O que aparece no lapso, no sintoma, como podemos ler na psicanálise, é uma espécie de regresso do corpo. Na escrita alfabética, para que possamos ler é preciso um apagamento da figuratividade, tanto sonora quanto visual. Mas as marcas estão lá no papel, na tela, no suporte.

Há no escrito um corpo escondido, recalcado: Garcia (1991) lembra que as crianças em processo de apropriação da escrita reconhecem certo bimorfismo inscrito nas letras, reconhecem o desenho que as letras carregam, que deve ser apagado, esquecido, para que a língua se produza. 
A aprendizagem da escrita processa-se como privação de um jogo erótico em proveito de um domínio do traçado, afirmam Cazade e Compagnon (1987). Mas, continuam os autores, é a própria nomenclatura das diferentes partes das letras que afirma a corporeidade do escrito:

O que é recusado ao nível do domínio ou do apagamento do corpo do sujeito elou da letra (...) resulta da nomenclatura técnica das diferentes partes das letras, que se pretendia sem cumplicidade metafórica ou metonímica, sem traço de sujeito. No entanto, com seu modelo médico, também esta anatomia mostra o corpo sexualizado, censurado, no qual se inscreve: é o que acontece com as pernas (elementos verticais das letras $m$, $n, u$ ), caudas (traço de uma letra que desce abaixo da linha da escrita), ou hastes. (...) (1987, p. 182)

Mais adiante, no mesmo texto, os autores lembram ainda que as letras possuem hastes, com conotações fálicas, que se opõem às argolas, partes arredondadas, sob as quais transparece toda uma fantasmática do corpo feminino (ibidem ).

Talvez seja exatamente este necessário apagamento do corpo no processo de apropriação da escrita que mobilize o interesse que podemos perceber nas crianças de 6,7 e 8 anos pelas piadas e anedotas que jogam com o corpo anunciado/apagado das letras, como nos exemplos a seguir:

$$
\begin{aligned}
& \text { O que fica no meio da rua com as pernas abertas? (A letra “ } u \text { ”) } \\
& \text { O que o homem tem dois e a mulher tem um? (a letra " } m \text { ") } \\
& \text { O que o gafanhoto tem na frente e a pulga tem atrás? (a sílaba "ga”) }
\end{aligned}
$$

Estas anedotas circulam na oralidade, mas marcam uma escrita: uma relação diferenciada com a língua, uma enganação na presença do corpo, uma metáfora da castração. 
Cecília Meireles traz também a corporeidade do escrito em uma poesia para crianças, "O mosquito escreve":

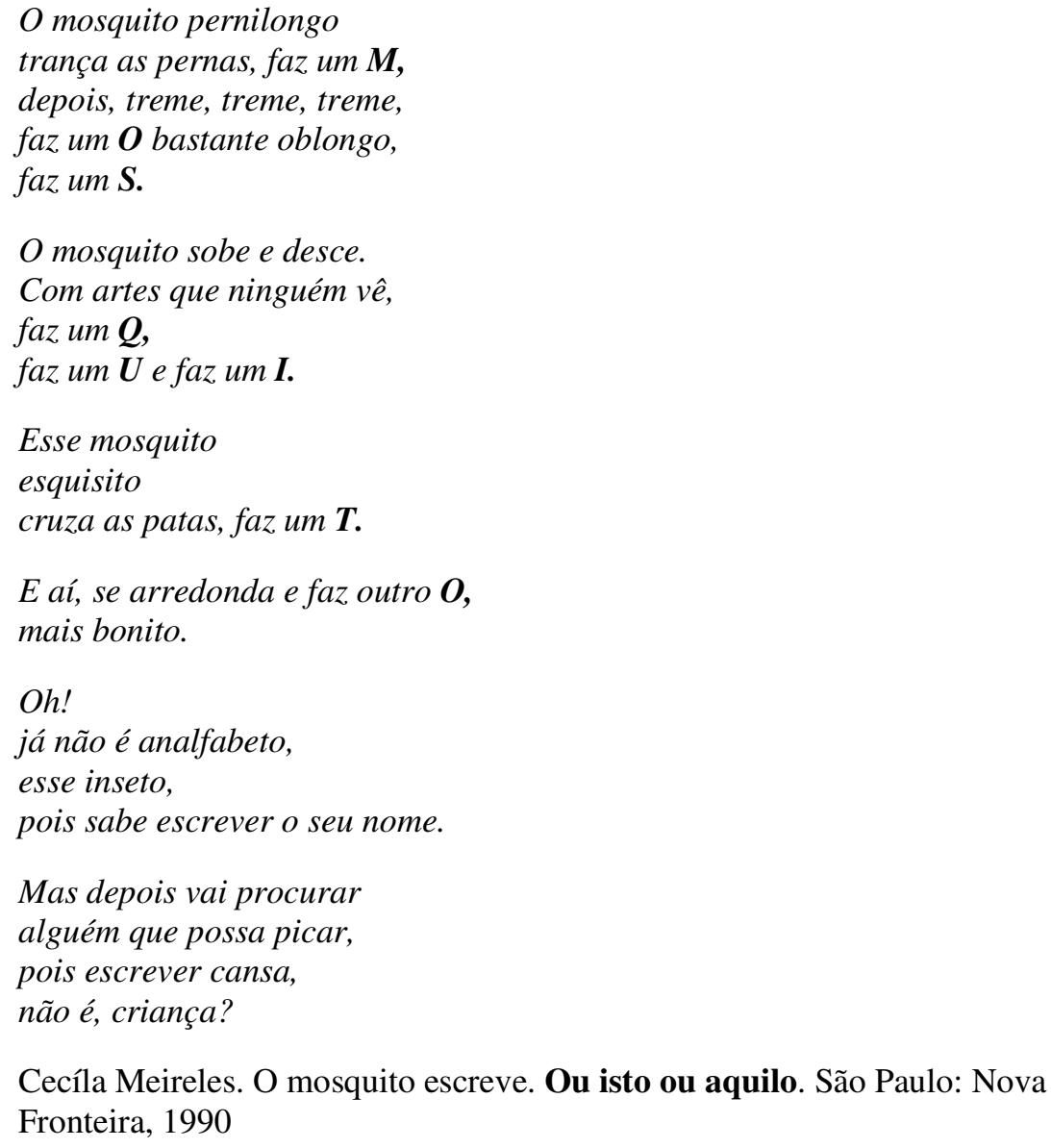

A poeta fala ao mesmo tempo do corpo do escrito e do corpo na escrita; escrever cansa, os movimentos que envolvem a constituição de um corpo escriba; o esforço em adestrar o corpo é facilmente perceptível nas crianças em processo de alfabetização.

Ao fazer distinção entre a escrita e o escrito, Barthes (1981) chama a atenção para as vicissitudes envolvidas no processo da escrita (que o autor nomeia scriptação): se o escrito nos permite imortalizar, fixar a palavra, ir além do alcance da voz, ele impõe perdas. Perde-se a expressividade primeira, a frescura das palavras; também caem as repetições, acertos fáticos da interação face a face da oralidade; perdem-se a prosódia, as modulações vocais através das quais um corpo procura outro corpo (1981, p. 11). 
O que Barthes indica é que, na oralidade, há uma evidência corporal, do olhar e da voz, que organiza a busca do outro. Ao escrever há perdas: perder; significa ser interditado, ser barrado. Estamos claramente no campo do entrecruzamento da Linguística, da Literatura e da Psicanálise.

O corpo do escrito - as letras, a pontuação, sua forma lingüística - é produto de uma prática discursiva, a escrita. No corpo do escrito encontram-se índices do corpo do sujeito que escreve. Para que o escrito tome corpo é preciso que outro corpo caia, o corpo daquele que escreve. A escrita envolve um posicionamento subjetivo, a presença de alguém que escreve com seu corpo, seus desejos. O sujeito do escrito é produto do recalque que opera na transcrição da palavra.

Ora, dizer que existe um corpo presente na leitura implica considerar que este corpo é marcado pela linguagem. É necessário que se confirme que, na leitura e na escrita alfabética, para ter acesso ao sentido é fundamental que se opere um corte na representação material das letras; para ler deve-se fazer cair a letra (Bergés, 1987); seu valor sonoro deixa de ser material para ser índice. Se atrelado ao real da letra, o leitor não lê o escrito, é apenas uma máquina de transpor materialidades; uma máquina que erra, já que o valor da letra é estabilizado pela escrita, como discurso, e não por sua fonetização.

Trago aqui uma ilustração preciosa: o momento em que uma criança, em pleno processo de alfabetização, procura estabilizar a pronúncia/leitura da palavra pelo acesso ao sentido. Ana, aos seis anos, jogava comigo "Palavra secreta" ${ }^{17}$. Nas primeiras jogadas, Ana precisava escrever as palavras que comporiam a palavra escondida, depois riscar a parte da palavra a ser descartada para fazer aparecer a palavra secreta. Em uma das rodadas Ana tira a seguinte carta:

\footnotetext{
${ }^{17}$ Jogo da Grow, em que uma palavra deve ser decifrada a partir de uma composição em rébus.
} 


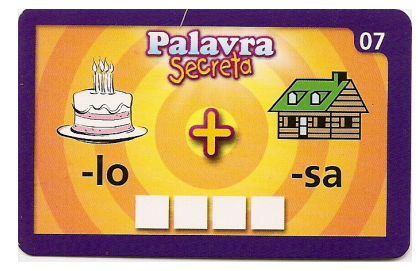

Figura 3 - carta do jogo "Palavra secreta"

A menina começa seu trabalho de detetive:

1. Ana escreve: bolo + casa

2. Rasura o fragmento a ser desprezado: bolo + casa

3. Ana isola as sílabas e lê: bó - bó / bo/ e então $\mathrm{Ca}$; /kA/ e finalmente / boka/ (que seria boca). Então se pergunta bóca? Bóca? Bó, bo, boca! A palavra é boca!

Ana percorreu todo o processo de estabilização, com o apagamento da materialidade sonora, permitindo ao "bo" ser desassociado parcialmente de sua sonoridade para que seu valor sonoro fosse dado pela língua, sem uma correspondência unívoca, mas relativizada pelo sistema.

A passagem das relações fala-escrito e fonema-grafema para uma dimensão não opositiva, nem tampouco correspondente, é o grande furo dos chamados métodos fônicos de alfabetização. Pois justamente quando a criança deixa de se ligar ao som da letra é que ela consegue abstrair o significado das palavras; quando a criança percebe que a letra A pode ser a , a, A ...ou que "bo" pode ser" bó" ou "bô", quando consegue estabilizar o valor do escrito desligado de sua materialidade, visual ou sonora, é que a criança realmente tem acesso ao significante e ao escrito.

Este processo, semelhante ao rébus de transferência, marca, ao mesmo tempo, na história da escrita alfabética, a passagem da figurativização para a fonetização, que implicaria a desconsideração do valor imagético para que a escrita funcione. É justamente este processo 
que também Freud associa à produção dos sonhos, dos lapsos e dos sintomas (Rego, 2006; Pommier, 1996).

A partir daí é possível pensar que, ao ler, é preciso comparecer com seu corpo não há linguagem sem corpo, diz Barthes (1981) - e disponibilizá-lo para o corte da língua. No corpo a corpo com o escrito produz-se uma nova inscrição: ato ao mesmo tempo assujeitado e criativo, a leitura em voz alta se sustenta na presença de um corpo recalcado.

Para Barthes (1981), no processo de scriptação (aqui chamamos de escrita), perde-se o corpo, o corpo da presencialidade do outro, envolvido na oralidade. Mas este corpo retorna, de uma maneira indireta, diz o autor, pela escrita (que aqui nomeamos escrita psíquica). O que são os lapsos de leitura, por exemplo, senão o retorno de um corpo?

Cabe trazer aqui uma cena ocorrida durante uma aula na Universidade. Estava com um grupo de alunas de graduação em fonoaudiologia, em fase preparatória para a prática da leitura em hospitais. Conversávamos justamente sobre a diversidade dos modos de ler e sobre a singularidade da prática leitora. Cada aluna lia em voz alta um pequeno livro infantil e discutíamos os efeitos. Era uma segunda feira, oito horas da manhã. A terceira aluna a ler, tomou o livro nas mãos, apresentou a capa para a audiência e leu o título:

\section{- Baladas e amigos, de Ana Maria Machado e Claudius.}

Imediatamente todo o grupo começou a rir. A aluna, desconcertada, procurava entender a reação da audiência. Pedi que ela lesse novamente o título do livro.

- Baladas e amigos, de Ana Maria Machado e Claudius. 
Novamente as risadas, ainda mais expansivas. E mais uma vez, pedi que lesse novamente. A cena se repetiu umas quatro vezes. A cada nova "leitura" a aluna tornava-se irritada, e já não mais lia, dizia o título do livro. Então pedi que ela se sentasse, fechasse os olhos por alguns segundos e novamente lesse, bem devagar, cada palavra escrita.

Foi então que ela leu:

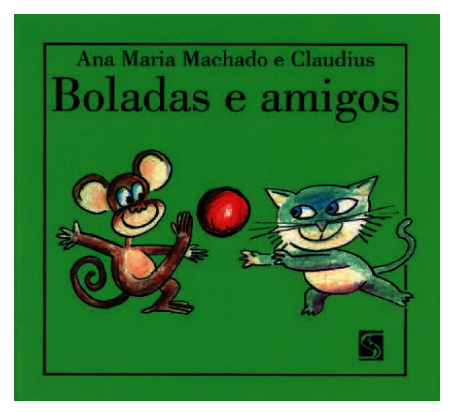

Figura 4 - capa do livro "Boladas e amigos"

- Boladas e amigos!

Imediatamente a aluna cobriu o rosto com o livro e começou a rir. A graça toda não está na substituição o/a, mas justamente na leitura prévia: após um fim de semana, amigos remete muito mais a baladas, que boladas, mesmo que a capa do livro - com imagens de animais e uma bola - pudesse direcionar a leitura. Trata-se de um lapso do primeiro tipo, como descrito por Freud: há alguma disposição prévia do leitor atuando na leitura. Mesmo limitado pelas regras da língua, o leitor se dá a ver nos buracos esculpidos na dura lei da língua.

Lembrando Iser (1996): o leitor cria o sentido do texto a partir dos vazios deixados no texto pelo autor. Mais além: o leitor escava espaços, mesmo num texto sólido, sem espaços. O sujeito é produzido por brechas que não estão prontas, são produto de um corpo a corpo entre leitor e texto. 
Ler pode representar uma vivência de alteridades: há um outro que lê em mim e há ainda um Outro que me diz o que deve ser lido. Para Milmann (2003) a leitura adquire um status de lugar do Outro, se pensarmos que sua organização atualiza um contrato feito pela comunidade que compartilha significações estabelecidas, a língua, e mais ainda, se considerarmos que o texto foi escrito por um outro. Mesmo quando o que se lê foi escrito pelo leitor, há um distanciamento que se cria pela escrita, fazendo com que mesmo aquilo que foi escrito pelo próprio leitor adquira um estatuto de alteridade. ( p. 38)

Também nesta direção, Barthes e Compagnon (1987) indicam que a relação leitor/autor/texto coloca em jogo linguagem e sujeito. Nas palavras dos autores, a leitura não ultrapassa a estrutura, [...], respeita-a, mas perverte-a (1987, p.198). Nesta perspectiva, ler é uma prática subjetivante: coloca em cena o sujeito, o outro e a língua. Escreve-se para os vizinhos ou para Deus, afirma Sartre (1967, p.114), declaradamente ateu.

Mas seria qualquer leitura uma prática subjetivante?

Acreditamos que não. A leitura pode funcionar subjetivamente se o leitor se engata na produção do sentido. Se ler é apenas uma atividade de decifração grafo-fônica, se ao leitor é apenas conferida a possibilidade de entender o texto, que tem sentido prévio e determinado, se o texto é uma impostura, então não podemos falar em prática subjetivante, mas ao contrário, dessubjetivante. Desengatado do leitor, o texto, de vida própria, não enlaça, não faz circular desejo. E sem desejo não há investimento, não há mudança, não há apropriação de novas posições.

\subsection{Leitura e desejo}

Ler é também decidir procurar alguma coisa. Quando existe leitura, existe uma carência a ser suprida, portanto, um apetite, um desejo. Bellenger, 1979, p. 83. 
Pensar a leitura como experiência de alteridade remete a outra questão: o desejo. Roudinesco (1998, p. 146), em seus comentários sobre o desejo, lembra que a relação com o outro passa pelo desejo.

Para Kaufman (1996), existem diferenças entre as formulações do desejo em Freud e Lacan. Freud fala em desejos - especialmente am A Interpretação dos Sonhos - e os liga a um movimento de realização-de-desejo, cuja satisfação é alucinatória. O desejo, em Freud, sempre inconsciente, insinua-se nos sonhos e em outras manifestações inconscientes. A escuta analítica permite, pela transferência, que o desejo seja nomeado pelo sujeito.

Já Lacan articula a noção de sujeito à necessidade e à demanda.

O princípio de que se trata este que é ao mesmo tempo o bê-á-bá, a infância de nossa experiência, mas para além do qual, há algum tempo, não se sabia mais avançar por falta justamente de saber formalizá-lo como bê-á-bá é este: o cruzamento, o intercâmbio ingênuo que se produz pela dimensão do Outro entre o desejo e a demanda. (2003, p. 199)

Esta articulação evidencia a condição humana, no sentido em que convoca a ordem biológica - necessidade, a ordem da linguagem -, a demanda, dirigida a um outro, e o comprovante da falta - o desejo da unidade perdida. O que claudica é o desejo. (Lacan, 2008, p. 193).

Se o que sustenta a relação com o outro é uma demanda e o desejo se constitui na diferença que o separa do amor e do saber, então a leitura - a que convoca o outro movimenta o desejo de encontrar, no texto, o saber perdido, origem do desejo no discurso (Lacan, 2008).

Birman (1996) articula desejo e leitura a partir das operações envolvidas na produção de sentido, sugeridas por Barthes e Compagnon (1987). De acordo com o autor, para que a leitura funcione subjetivamente é necessário que o leitor possa se colocar de maneira crítica e criativa na relação com o escrito. Esta posição é o resultado de operações de leitura, na produção do sentido, quais sejam: reconhecimento e compreensão. Nesta primeira 
operação, o reconhecimento, o leitor se encontra com o texto, é surpreendido por ele. $\mathrm{Na}$ compreensão, o leitor opera uma reorganização dos sentidos, produzindo seu ato criativo.

$\mathrm{Na}$ operação de reconhecimento do texto, Birman indica que o leitor é tomado por um efeito de ruptura, de novidade. Este efeito funciona como uma interpretação; provoca a desconstrução do eu leitor, mas revela simultaneamente a positividade de seu desejo (1996, p. 57).

Tal operação provoca uma posição de suspensão, que é desfeita na compreensão: o leitor reordena os sentidos, criando novas possibilidades. Birman reconhece nestas operações uma cena erótica, que captura o sujeito. Frente ao novo, na posição de reconhecimento/interpretação, o sujeito se inscreve em uma posição de passividade; já na operação de compreensão/construção o leitor assume a posição de atividade, produzindo um sentido do texto. Nesta perspectiva, a leitura se realiza para o leitor entre os pólos da atividade e da passividade, duas formas diversas de economia erótica para o leitor (1996, p. 59).

Também Virginia Woolf (2007) reconhece dois procedimentos na leitura. Em um primeiro procedimento, o leitor recebe as impressões com a máxima vontade de entender (ibidem, p. 132); esse procedimento parcial de leitura será completado por um procedimento posterior que reorganiza os modelos provisórios, pressupondo uma separação entre a imediatez da leitura do texto, e um afastamento, marcando um tempo em que o texto retorna para ser ressignificado:

Aguarde que a poeira da leitura abaixe; que o conflito e as indagações se aquietem; caminhe, converse, amasse pétalas murchas de uma rosa, ou durma. Então, de repente, sem que ansiássemos por isso, pois é assim que a Natureza se encarrega destas mudanças, o livro retornará, mas de forma diferente. (Woolf, 2007, p.132) 
Os movimentos eróticos supostos por Birman e os procedimentos de leitura de Woolf remetem aos processos de produção da subjetividade descritos por Lacan (1990, 1998, 2008): a alienação e a separação.

Ler envolve um momento de entrega, em que se espera algo do texto; o leitor imagina poder encontrar, no escrito, aquilo que lhe falta, daí a alienação.

Ler é identificar-se com o apaixonado ou com o místico. É ser um pouco clandestino, é abolir o mundo exterior, deportar-se para uma ficção, abrir $o$ parêntese do imaginário. Ler é muitas vezes trancar-se(no sentido próprio e figurado) ( Bellenger, L, 1979, p. 17)

Todavia, também lembra Woolf (2007), Não há uma janela aberta do lado direito da estante? que delícia parar de ler e olhar lá fora (2007, p. 128). O leitor espera encontrar no escrito aquilo que falta, mas sua expectativa é frustrada pelo próprio processo de leitura: o texto só aparece com seus sentidos à medida que nos afastamos dele. A necessária participação do leitor na construção do sentido estabelece um paradoxo que promove a separação: o texto não é completo sem a intervenção do leitor, portanto impossível que o escrito obture os buracos do leitor.

No entanto, ler transforma (Belleger, p. 105). Mesmo não tendo encontrado a unidade almejada, a leitura coloca em cena rearranjos significantes, produz uma escrita que faz aparecer sujeito, que areja inscrições, que afeta e, portanto, promove desejo de ler mais.

Trago aqui mais uma ilustração: o efeito de ruptura mobilizando a criança no sentido da leitura. Quando a cena a seguir se deu, Rafael estava em atendimento fonoaudiológico havia dois anos, em função de uma encefalite, complicação de um quadro de meningite viral, quando tinha sete anos. Ao iniciar o atendimento fonoaudiológico, Rafael falava apenas "não", e realizava algumas emissões vocálicas. Durante dois anos de atendimento fonoaudiológico Rafael conquistou muito: passou a falar fluentemente, embora algumas questões de linguagem permanecessem; em processo de alfabetização, frequentava escola regular, manifestando muitas dificuldades. 
Nas sessões de fonoaudiologia, Rafael nunca tinha demonstrado qualquer interesse por livros e nem mesmo por outros portadores de texto, embora eu lhe oferecesse grande variedade de material para que ele explorasse sozinho ou comigo. Rafael parecia simplesmente desviar os olhos dos livros e não se interessava absolutamente por histórias infantis até a cena descrita a seguir.

Em uma sessão, tomei um livro que estava me encantando naqueles dias e comecei a ler para Rafael. Naquele momento sua reação foi surpreendente: primeiro, parou de brincar com os brinquedos no chão da sala; depois parecia olhar para o nada. Na verdade, escutava. O menino começou então a sorrir e depois a gargalhar, conforme eu avançava na leitura. Finalmente aproximou-se de mim, olhou demoradamente o livro, folheando-o e perguntou: "estava escrito isso que você falou"? O menino se aproximou, observou as imagens que acompanhavam o texto. O conteúdo imagético, no livro em questão, funciona como um elemento de redundância do escrito. A leitura de imagens permitiu ao garoto confirmar minha leitura. Finalmente Rafael comentou:

\section{- Este livro não é igual.}

A partir desta cena, Rafael passou a buscar os livros. Tornou-se um "escutador" interessado e passou após alguns meses a se lançar nos rituais de apropriação da escrita.

O que li para Rafael:

Não confunda

Gorila gigante

Com mochila chocante

Não confunda

Velhota nariguda

Com gaivota bigoduda

Não confunda

Feioso amarelado
Não confunda

Hipopótamo arrumado

Com helicóptero enfeitado

Não confunda

$O$ vizinho do Nicolau

Com o padrinho do Juvenal

Não confunda

Ovelha abelhuda 


\author{
Com medroso esverdeado \\ Não confunda \\ Picolé salgado \\ Com jacaré mimado \\ Não confunda \\ Peteca violenta \\ Com meleca nojenta \\ Não confunda \\ Careca banguela \\ Com cueca amarela \\ Não confunda \\ Cabelo curto \\ Com camelo surdo
}

\author{
Com abelha orelhuda \\ Não confunda \\ Cachecol de borboleta \\ Com caracol de maleta \\ Não confunda \\ Coceira de porquinho \\ Com banheira de patinho \\ Não confunda \\ Vaca empacotada \\ Com paca avacalhada \\ Não confunda \\ Queijo e uma mordida \\ Com beijo de despedida
}

Eva Furnari, Não confunda, 2002

O que desconcertou Rafael é difícil afirmar. Imagino que algo do nonsense e também do poético tenha tocado o menino, que mesmo podendo se comunicar bem, ainda sofria com os resquícios de sua afasia, com produções aparentemente sem sentido. De qualquer modo fez-se um laço: o menino começou a se movimentar na escrita. Algo do não confunda possibilitou a reordenação de suas confusões? As bizarras e inusitadas semelhanças diziam respeito à sua história? Talvez. No entanto, podemos argumentar que o movimento de Rafael esteja atrelado à dinâmica do desejo na relação com o outro e o Outro.

O "não confunda", aqui trazido pela voz de Eva Furnari, é um conhecido trocadilho da oralidade, que joga com os traços de semelhança fonológica da língua e a impossibilidade de confundir o que a palavra representa, normalmente com pitadas de sexualidade. Podemos ler aí uma metáfora da arbitrariedade do signo linguístico, que remete também ao escape da lei pelo nonsense.

Rego (2006, p. 207) lembra que a técnica do chiste, revelada por Freud, envolve justamente a essência do "não confunda": $O$ nonsense seria uma via privilegiada para a descarga pulsional. Diante dele, até a licenciosidade e a agressividade são pretextos. 
A autora lembra, a partir da teoria freudiana, que a verdade do funcionamento do inconsciente é seguir as "associações superficiais": rimas, assonâncias, aliterações. E a partir de Lacan, Tavares (1998, p. 106) indica: a homofonia, os jogos com a polifonia significante trazem à cena um pouco de alíngua, nutrida pelos significantes primeiros, que se mantêm no inconsciente, sem fazer palavra.

Ainda para Rego (2006), há neste jogo um prazer liberado, o subornar o ego, cedendo a sua compulsão lógica, ao mesmo tempo afirmando o nonsense.

Vejamos outra ilustração:

O mesmo texto, "não-confunda", provocou efeitos interessantes, em outra situação bem diversa. A cena teve lugar durante uma das oficinas de leitura, "Brincar de Ler" 18. A oficina em questão envolveu a capacitação de 20 detentas do presídio feminino de Santana $^{19}$, para que funcionassem como multiplicadoras de uma série de atividades envolvendo leitura para crianças pequenas. O objetivo central era fornecer subsídios às detentas para que pudessem oferecer, como presente, a leitura de livros infantis, por ocasião das visitas de filhos e outras crianças no presídio, no dia da criança, 12 de outubro.

O ambiente da oficina, hostil, vigiado, tenso. A entrada no presídio, cercada de revistas e entrevistas. O material, confiscado - canetas podem ser armas, máquina fotográfica registra sabe-se lá o quê. Entrei com as roupas do corpo e meus livros. Com cerca de uma hora de atraso, devido a "problemas de disciplina" em um dos três pavilhões que compõem o presídio, tem inicio por fim a oficina.

\footnotetext{
${ }^{18}$ Estas oficinas foram concebidas e ministradas por mim, organizadas pelo Instituto Ecofuturo, como parte de atividades preparatórias para a comemoração, pela primeira vez em 2008, do Dia da Leitura no Estado de São Paulo. Para detalhes consultar: www.ecofuturo.com.br/programa_ler_e_preciso

19 Zona norte da Cidade de São Paulo; trata-se do maior presídio feminino da América Latina, com cerca de 3.000 detentas. As detentas que participavam da oficina se inscreveram voluntariamente. A oficina foi oferecida a um grupo seleto de detentas, que atuam como educadoras dentro do presídio, e que, por este trabalho, recebem uma gratificação financeira e possibilidade de redução da pena, também em função do crime cometido e do histórico de comportamento na detenção.
} 
Após as apresentações formais e algumas pontuações sobre a atividade a ser desenvolvida - as detentas, sérias, desconfiadas -, decido passar logo à prática: começo a ler alguns livros de literatura infantil que havia selecionado para a leitura, entre os quais Não confunda.

À medida que eu lia o texto, o ambiente se descontraía: risadas, mais risadas, comentários; a audiência se movimentava nas cadeiras. O grupo parecia outro após a leitura: as mulheres buscavam os livros, integravam-se perfeitamente às atividades propostas. Ao final da oficina, uma certeza: algo se movimentou na audiência.

Rafael e as detentas do presídio de Santana efetivamente não leram a história com seus olhos, ouviram-me lendo; je lis avec mes oreilles, como diz Marc Roger, da Associação francesa de leitores públicos ${ }^{20}$. Uma questão naturalmente se impõe: teria o texto a mesma força mobilizadora se não tivesse sido lido em voz alta?

\subsection{Ler e escutar}

Eu me aquietava (...) Ouvia minha babá ler os aterrorizantes contos de fada dos irmãos Grimm. Às vezes a voz dela me fazia dormir, outras vezes, ao contrário, deixava-me numa excitação febril, e eu insistia em que ela descobrisse, mais rápido do que o autor pretendia, o que aconteceria na história. Na maior parte do tempo eu simplesmente gozava a sensação voluptuosa de ser levado pelas palavras e sentia, num sentido muito físico, que estava de fato viajando por algum lugar maravilhosamente longínquo, um lugar que eu dificilmente arriscaria espiar na última e secreta página do livro " Manguel. A. 2006, p. 132

A leitura em voz alta apresenta especificidades que a dimensionam como marcadamente corporal; trata-se de uma modalidade de leitura em que jogam diversos elementos na produção de efeitos de sentido.

Ao introduzir a noção de performance na leitura Zumthor (2007, p.50), dimensiona a recepção no ato da leitura. A performance é então um momento da recepção: 
momento privilegiado, em que um enunciado é realmente recebido ${ }^{21}$. Para o autor, desde o oral, o poético e a leitura silenciosa, há uma gradação performática, uma presença em maior ou menor grau de uma teatralidade, uma vocalidade, que envolveria a passagem da linguagem ao ato, do texto ao corpo.

Assim, na situação com audição acompanhada de uma visão global da situação de enunciação (como é o caso da leitura em voz alta), temos a performance completa; nas gravações e radiodifusões de textos, em que se perde o componente presencial, a performance perde força e, finalmente, na leitura silenciosa, observamos a performance em menor grau.

O espaço em que se inscrevem uma e outra (a performance teatral e a leitura) é ao mesmo tempo lugar cênico e manifestação de uma intenção de autor. A condição necessária à emergência de uma teatralidade performancial é a identificação, pelo espectador-ouvinte, de um outro espaço; a percepção de uma alteridade espacial marcando o texto. Isto implica alguma ruptura com o "real" ambiente, uma fissura pela qual, justamente, se introduz uma alteridade. (2007, p. 41, grifo nosso)

Na leitura em voz alta, a situação presencial de leitores e ouvintes/leitores cria um espaço de enunciação diferenciado. Há uma cena de leitura em que o corpo leitor é visto e ouvido. Aquele que lê em voz alta está evidentemente na relação com o texto, mas também, endereça sua leitura ao outro, que o escuta. O leitor empenha seu corpo na produção do sentido do texto e na oferta ao outro. Ele se dá a ver e a escutar em sua relação com o texto. Tal prática implica a invocação do outro, o chamamento pela voz. Quem escuta está também em posição de leitura, na relação com o texto, mas também na relação com o leitor, como testemunha de sua subjetividade, como convocado a penetrar na intimidade da cena de leitura pelo olhar e pela escuta. Mais adiante, no capítulo 4, exploraremos com maior profundidade

\footnotetext{
${ }^{20}$ Comunicação verbal proferida durante o Estágio de Formação em Leitura Pública. Associação La Voie des Livres, Paris, setembro de 2007.

${ }^{21} \mathrm{O}$ termo desempenho, como introduzido por Zumthor, não coincide absolutamente com o termo utilizado por Chomsky (1971) a respeito do desempenho de falantes na língua.
} 
as implicações da presencialidade na cena da leitura. Por ora, continuemos a trabalhar com a noção de escuta.

O gesto de oferta, de dar-se a ver e de ser ouvido, marca claramente a leitura como ato, colocando-a em uma dimensão evocativa (em relação o texto) e invocante (em relação ao ouvinte). A partir daí, do trabalho evocativo com a palavra, como observa Birman (1996), circulam corpo e desejo na leitura: pela voz e pela escuta.

Escutar, ato psicológico, difere de ouvir, ato fisiológico. (Barthes, 1987). A escuta envolve o desvendamento de um sentido, a partir da articulação do dito e do não dito. A partir da psicanálise, a escuta remete a um posicionamento de atenção flutuante em que o saber sobre o que se escuta não é dado a priori, mas é um efeito de um aparelho de linguagem sobre outro.

No texto Recomendações aos médicos que exercem a psicanálise, de 1912, Freud expressa a regra para o médico escutar seu paciente: ele deve conter todas as influências conscientes da sua capacidade de prestar atenção e abandonar-se inteiramente à 'memória inconsciente”. (...)'Ele deve simplesmente escutar e não se preocupar se está se lembrando de alguma coisa.

Barthes (1987) observa que, a partir da psicanálise, a escuta toma um sentido diferente daquele que tradicionalmente se impunha: ato intencional de audição. Para além da leitura do inconsciente, a escuta passa a poder significar uma abertura para todas as formas de polissemia, de implícitos, de não ditos.

Neste sentido, escutar alguém lendo é também posicionar-se intersubjetivamente, em estado de recepção. Aquele que escuta a leitura não apenas recria o texto a partir de sua relação mesma com o material linguístico, mas, principalmente, envolve-se com as materialidades corporais implicadas no ato; recebe as variações melódicas e rítmicas que, para além da língua, significam um sujeito. A escuta da voz inaugura a relação com o outro: 
a voz pela qual se reconhecem os outros indica-nos as suas maneiras de ser, as suas alegrias ou sofrimentos, os seus estados; veicula uma imagem do corpo... (Barthes, 1987, p. 142).

A voz não é qualquer corpo. É o corpo que se lança no espaço, na direção do outro. É o transbordamento do corpo para fora dele mesmo, tocando o corpo do outro, mesmo a distância, pelos ouvidos. Se os olhos capturam, a voz chama. A voz é o corpo que vai ao outro e que volta em si mesmo, como observa Zumthor (2007).

Assim, ao ler em voz alta, o leitor toca o outro, mas toca a si próprio. Escutar-se é também reconstruir sentidos. Em uma publicação anterior (As vozes da leitura, Pastorello, 2004), comento um atendimento clínico em que a leitura em voz alta reorganiza a fala de uma criança, que a partir desta prática consegue caminhar pela oralidade sem os tropeços articulatórios.

Nossas sessões passaram a centrar-se em atividades de lecto-escritura, porque ele solicitava. Ao ler em voz alta, até sua postura física alterava-se: orgulhoso, sentava-se ereto na cadeira. Altivo, não cometia deslizes articulatórios, mas frente a palavras difíceis, desconhecidas ou que envolviam relações com sua dificuldade de fala. B. se corrigia, interrogavame: dizia do seu saber com naturalidade. (Pastorello, 2004, p. 127)

Retomando nosso questionamento - sobre se a vocalidade interferiria na recepção do texto por Rafael e pelas detentas do presídio de Santana -, podemos afirmar que a natureza performática e invocante da leitura do texto, aliada à própria forma do texto - que introduz o inusitado, abre campos de sentido, provoca uma estabilização do sem sentido. A vocalidade certamente interferiu, de maneira positiva, na recepção e no efeito provocado.

A posição de escuta de Rafael também parece ter sido determinante. Rafael brincava enquanto eu lia, mas escutava e foi capaz de ler o texto. O estranhamento operado pelo texto o desconcertou e provocou um movimento de tentativa de estabilizar um sentido: a criança procura ver o livro, movimenta-se, busca uma leitura. Está em ato a cena erótica, de passividade/atividade, descrita por Birman (1996). Tal experiência promove uma 
movimentação da relação de Rafael com o escrito: ele parte em busca de outros livros, na procura de re-experimentar o prazer vivido.

Também a leitura no presídio parece ter posto em jogo as relações de expectativa sobre o que é ler e o que se pode fazer com a leitura. Como multiplicadoras da atividade e a partir do desconcerto provocado na escuta do "não-confunda", é possível que as detentas tenham experimentado a possibilidade de ser o outro; de ofertar, a partir do texto e da voz, uma criação alternativa.

Ferreira Gullar², a respeito da escuta da voz de Nara Leão, comenta em Uma voz:

A voz dela, quando ela canta, me lembra um pássaro

Não um pássaro cantando, Me lembra um pássaro voando.

Podemos imaginar que a atividade de ler/escutar o texto envolve marcadamente um laço identificatório. Se a voz é um chamado, uma invocação, a escuta é uma abertura para o outro. Para Barthes a escuta revela um apelo de um sujeito ao outro: "ouça-me” quer dizer “toque-me, saiba que eu existo”. (1987, p. 140)

No engate com o outro a partir da leitura em voz alta, abre-se também o espaço para fruição significante, para a repetição, a expectativa de se surpreender com o texto. As sensações gozosas, um respingo de alíngua provocada pela materialidade do texto "não confunda", movimentam aquele que escuta: "fui tocado, quero fazer o mesmo". O desejo aí recai sobre o texto, instaura a procura, de ter o texto, de lê-lo, de buscar a repetição do momento em que se toca o prazer.

Esse prazer indizível, experimentado em algumas situações, impulsiona muitas vezes o desejo e a procura do sujeito na direção do objeto imaginariamente associado à

\footnotetext{
${ }^{22}$ Bosi, Ferreira Gullar: seleção ,2004.p.86
} 
satisfação. Este movimento, acreditamos, pode impulsionar a apropriação da escrita, pelo desejo de incorporação do escrito.

Clarice Lispector, em Felicidade Clandestina, testemunha sua relação desejante com um livro em particular:

Às vezes, sentava-me na rede, balançando-me com o livro aberto no colo, sem tocá-lo, em êxtase puríssimo.

Não era mais uma menina com um livro: era uma mulher com o seu amante.

(Clarice Lispector, Felicidade Clandestina.,1971.)

Também Graciliano Ramos testemunha, em "Infância”, muitos de seus momentos no difícil trato com o aprendizado da leitura e da escrita. Diferentemente de Sartre - que vivia em uma sociedade letrada, em uma família de leitores e escritores e que testemunha os momentos de intimidade com sua mãe frente à leitura -, Ramos se via em uma sociedade em que ler era a exceção (Silva, 2004), e a herança parental da leitura era catastrófica.

Minha mãe lia devagar, numa toada inexpressiva, fazendo pausas absurdas, engolindo vírgulas e pontos, abolindo esdrúxulas, alongando ou encurtando as palavras. Não compreendia bem o sentido delas. E, com tal prosódia e tal pontuação, os textos mais simples se obscureciam. (Ramos, Infância 1993, p.63).

Assim mesmo, o autor vai recolhendo os momentos em que, pela mão do outro, algo se encantava no corpo a corpo com o escrito, como nas situações vividas com uma das professoras:

Aquela brandura, a voz mansa, a consertar-me as barbaridades, a mão curta, a virar a folha, apontar-me a linha, o vestido claro e limpo, tudo me seduzia (...). Agora livre das emanações ásperas, eu me tranqüilizava. (Ramos, 1993, p.110).

Até que, no entrejogo do "que queres de mim?" com sua prima Emília, Graciliano Ramos pô de se movimentar em direção à apropriação da leitura.

Assim, era necessário que a priminha lesse comigo o romance e me auxiliasse na decifração dele. Emília respondeu com uma pergunta que me espantou. Por que não me arriscaria a tentar a leitura sozinho? 
Longamente the expus a minha fraqueza mental, a impossibilidade de compreender as palavras dificeis, sobretudo na ordem terrivel em que se juntavam (...). Emília combateu a minha convicção, falou-me dos astrônomos, indivíduos que liam no céu, percebiam tudo quanto há no céu (...) E tomei coragem, fui esconder-me no quintal, com os lobos, o homem, a mulher, os pequenos, a tempestade na floresta, a cabana do lenhador. (Ramos, 1993, p. 190-191).

E, finalmente, a percepção de que o outro é também interditado pela língua pode permitir entrever o Outro.

Aí me caiu a leitura de uma das maçadas de Samuel Smiles. Tossi e resmunguei a segunda palavra enchendo a boca de língua. O professor interrompeu-me, separando as sílabas com bastante clareza: Samuel Smiles. (...) A firmeza séria me deu a suspeita que me achava na presença de uma autoridade (...) O professor não podia se comparar aos viventes comuns. Grave, o dedo na página: Smiles. Nas lições seguintes percebi que não se contradizia. Comecei então a admirá-lo (Ramos, 1993, p.194-195).

Nesta passagem de Infância, Ramos comenta situações em que dizia o nome Smiles em contextos diferentes e era repreendido: "esmiles" seria o correto. Mas a figura do professor, sua consistência e segurança, sua sujeição ao escrito, colocavam-no como aquele que sabe, e não à toa Graciliano passa a admirá-lo: ele tem o que me falta.

Estamos aí na dimensão da identificação, num momento de alienação do sujeito que se sabe faltante, como diz Lacan, no seminário IX, e que acredita que o outro seja nãofaltante. Talvez algo desta ordem tenha se mobilizado nas leituras do "não-confunda". Voltaremos a esta questão sobre a identificação mais adiante, quando ao centralizar a cena de leitura em voz alta, focaremos justamente o processo identificatório envolvido nesta prática.

Por enquanto, uma última ilustração clínica neste capítulo, que nos permite vislumbrar o escrito na leitura em voz alta e as mudanças de posição do sujeito na relação com o Outro, a partir do outro.

Rodrigo, de nove anos, está em atendimento fonoaudiológico comigo em função de diagnóstico de dislexia, conferido por um neurologista, que sugeriu o atendimento. Seu irmão mais velho, Daniel, também recebeu o mesmo diagnóstico e enfrenta graves 
dificuldades escolares. A família buscou meu atendimento por sugestão de uma amiga da mãe de Rodrigo, cujo filho atendi, também chamado Daniel, que apresentava importantes dificuldades na linguagem oral e escrita.

Este menino, Rodrigo, que cursa o terceiro ano de uma escola particular, diz ter dificuldade para ler, escrever e falar. Nas sessões lemos bastante. Rodrigo está em atendimento há cerca de um ano, com muitos progressos. No início do atendimento, ele evitava atividades de leitura e de escrita; frente a estas situações tornava-se ansioso e todo seu corpo se agitava: balançava as pernas, movimentava o tronco, curvava as costas como se quisesse se enrolar como um bebê. Ao ler em voz alta sua voz era débil, sua articulação imprecisa; era difícil reconhecer o que o garoto lia, em parte por sua imaturidade na leitura, em parte por sua expressão comprometida.

Embora ainda persistam dificuldades na leitura, principalmente intensiva, Rodrigo movimentou-se. Durante a leitura em voz alta Rodrigo apresenta substituições e equívocos - esperados para uma criança que ainda não domina a fluência leitora- mas está ligado de outra forma ao escrito. Rodrigo afirma gostar de ler; chega às sessões sempre acompanhado de uma revista, ou livro, que quer compartilhar comigo. Lemos sempre o material que ele traz, e outros que lhe ofereço. A família e a escola comentam seu desempenho leitor e seu interesse crescente por livros e todo material escrito.

Os erros de leitura que Rodrigo comete, em sua maioria, podem ser interpretados como equívocos classicamente descritos na literatura fonoaudiológica: inadequações na decodificação grafema-fonema por desvios perceptuais ligados ou a sonoridade (como [f] $[\mathrm{v}]$; $[\mathrm{t}]-[\mathrm{d}]$, por exemplo) ou a visibilidade (como $[\mathrm{p}]-[\mathrm{b}],[\mathrm{d}]-[\mathrm{p}]$. Mas recentemente um equívoco me provocou estranheza.

Estávamos lendo Como viver para sempre, romance juvenil que Rodrigo referiu ter lido, mas que queria ler de novo, comigo, em voz alta. Em algumas sessões, Rodrigo 
coloca a "platéia" de nossa leitura pública: canetas, borracha e alguns lápis, dispostos em um porta-lápis de pedra sabão, que sustenta o material, como uma platéia, pessoas em pé. Esta curiosa brincadeira surgiu em uma das sessões, quando conversávamos sobre as diferenças entre a leitura em voz alta e a leitura silenciosa. Na situação que trago agora, não havia platéia.

Rodrigo cometeu poucos erros em sua leitura, mas o que me chamou a atenção foi uma substituição: "lareira" foi lido como "ladeira". Quando lhe chamei a atenção, ele insistiu na "ladeira" por mais algumas vezes, até que chegou em "lareira" e riu. Eis o trecho lido na página 14:

Depois de trocar de roupa e secar o cabelo, Pedro sentou-se com o avô diante da lareira, e eles conversaram sobre o dia, como faziam todas as tardes., (Colin Thompson,. 2008, p.14, grifo nosso.)

A singular operação de Rodrigo: [r] - [d] não é uma substituição comum, seja de ordem sonora ou visual. De onde veio este [d], me perguntava. Pommier (1996), apoiando-se na tese lacaniana de que o inconsciente escreve, mesmo antes do domínio da representação gráfica, comenta casos clínicos de crianças atendidas por ele, em processo de alfabetização. Para o autor, na aprendizagem da escrita, o que está em jogo para a criança é a questão da representação. De acordo com esta perspectiva, as formas como o sujeito - criança e adulto utiliza a representação gráfica podem falar de seu sintoma. Em um dos exemplos clínicos, Pommier fala da equivalência entre um sintoma e uma letra.

Revendo o equívoco de Rodrigo. Há um [d] que se insinua. D de dislexia? De Daniel irmão? De Daniel, aquele que precisa de atendimento fonoaudiológico? Uma interpretação selvagem nos levaria a imaginar que "ladeira" poderia nos remeter à dificuldade em caminhar na leitura, ou ao desejo de se livrar dos "d" que o atormentam. Mas não é disso que trato em meus atendimentos. O que interessa é marcar que a escuta das singularidades de 
Rodrigo pode fornecer indícios de como ele caminha em sua apropriação da escrita. Ler em voz alta é, pensado desta forma, revelar uma escrita psíquica.

Em atenção aos sons da língua, a escrita em voz alta não é fonológica, mas fonética; o seu objectivo não é a clareza das mensagens, o teatro das emoções: o que ela procura (numa perspectiva de fruição) são os incidentes pulsionais, a linguagem revestida de pele, um texto onde se possa ouvir o grão da garganta, a pátina das consoantes, a voluptuosidade das vogais, toda uma estereofonia da carne profunda: a articulação do corpo, da língua, e não a do sentido, da linguagem. (Barthes, 1970:116.)

Note-se que Barthes afirma que a escrita em voz alta é fonética e não fonológica? O que quer dizer com isso? É o que examinaremos no próximo capítulo ao tratarmos das relações entre o som, o sentido, a língua e a dinâmica pulsional. 


\title{
Capítulo 3: Corpo sonoro e leitura em voz alta
}

\author{
antes de existir computador existia tevê \\ antes de existir tevê existia luz elétrica \\ antes de existir luz elétrica existia bicicleta \\ antes de existir bicicleta existia enciclopédia \\ antes de existir enciclopédia existia alfabeto \\ antes de existir alfabeto existia a voz. \\ antes de existir a voz existia o silêncio \\ o silêncio \\ foi a primeira coisa que existiu \\ um silêncio que ninguém ouviu \\ astro pelo céu em movimento \\ e o som do gelo derretendo \\ o barulho do cabelo em crescimento \\ e a música do vento \\ e a matéria em decomposição \\ a barriga digerindo o pão \\ explosão de semente sob o chão \\ diamante nascendo do carvão \\ homem pedra planta bicho flor \\ luz elétrica tevê computador \\ batedeira, liquidificador \\ vamos ouvir esse silêncio meu amor \\ amplificado no amplificador \\ do estetoscópio do doutor \\ no lado esquerdo do peito, esse tambor
}

Arnaldo Antunes ,O Silêncio, 1996

Arnaldo Antunes introduz uma sonoridade simbolizada, não física, não audível, mas de alguma forma, reconhecível: o barulho do cabelo em crescimento... O som do gelo derretendo. Som, aqui, traz uma dimensão de temporalidade, de algo que acompanha a vida, mesmo em suposto silêncio.

Aqui começamos a nos aproximar da matéria prima com a qual construiremos nosso conceito de corpo sonoro: a possibilidade de reconhecer a sonoridade em seu aspecto simbólico, não apenas físico ou necessariamente material. Mais ainda, consideramos a sonoridade em suas múltiplas dimensões - audíveis e cinestésicas: o ritmo, a intensidade, a frequência e os timbres (Schaffer, 1991). Finalmente, partiremos para a investigação das 
questões que se impõem quando articulamos sonoridades, apropriações linguageiras e emergência subjetiva.

\subsection{Antes de existir a voz, existia o silêncio}

Para o Músico canadense Shaffer (1991), vivemos em um ambiente constantemente sonorizado. A paisagem sonora - termo introduzido por ele nos anos 1970, para dar conta de refletir sobre as possibilidades de percepção e intervenção musical em diferentes ambientes não convencionalmente destinados a apresentações musicais - compõe a vida social de cada um e interfere no organismo e na vida psíquica. A motivação artística que impulsiona o trabalho de Schaffer é justamente agir criativamente na composição da paisagem sonora a partir de diferentes fontes sonoras, independentemente de tais fontes serem tradicionalmente musicais ou não. O trabalho de Shaffer procura ampliar o conceito de musicalidade, incorporando à criação artística elementos sonoros que não eram escritos na pauta, que estavam além da notação musical. Para sustentar sua produção, o músico faz distinção entre música e ruído, argumentando por uma organização estrutural, especialmente rítmica e harmônica da música, em oposição ao caráter eventual e desorganizador do ruído.

No campo da linguagem, a sonoridade é tratada sob dois aspectos: linguístico e paralinguístico. A partir de Saussure (1970), com a conceituação de signo linguístico, a sonoridade, como constituinte da palavra, é determinada pelo recorte da incidência da língua na substância sonora percebida. O que importa na palavra não é o som em si, mas as diferenças fônicas que permitem distinguir essa palavra de todas as outras, pois são elas que levam a significação. Saussure, 1970, p. 137 
A língua é forma e não substância, ensina Saussure. A forma toma corpo pelo signo linguístico, cujas características principais são sua natureza arbitrária, sua dupla face significado/significante, seu caráter linear e seu valor determinado pelas relações entre os elementos e não por sua presença isolada no sistema.

Jakobson (1977), mesmo mantendo com Saussure uma postura estruturalista para a conceituação de língua, complexifica a questão da sonoridade e dos sentidos a partir do questionamento sobre o lugar da fonologia na linguística, sobre a arbitrariedade e a linearidade do significante.

Sobre o lugar da fonologia e da fonética, Jakobson enfatiza a inserção da primeira no campo da linguística, deixando a segunda para o campo das "disciplinas auxiliares", já que o que faz língua são as relações fonológicas e não os elementos fonéticos da produção do fonema, que são da ordem da fala. No Curso de lingüística geral, Saussure havia colocado a fonologia fora da linguística: a Fonologia, cumpre repetir, não passa de disciplina auxiliar e só se refere à fala. (1970, p.43), diz Saussure. Ao que Jakobson contra-argumenta:

Os sons da linguagem não podem ser compreendidos, delimitados, classificados, explicados senão segundo o ponto de vista das tarefas que desempenham na língua. A descrição motora, acústica e auditiva da matéria fônica deve estar subordinada à sua análise estrutural. Por outras palavras, a fonética, disciplina auxiliar, deve ser posta a serviço da fonologia que é, essa sim, uma parte integrante da lingüística (Jakobson, 1977, p.85)

A discussão sobre a linearidade do signo linguiístico é criticada por Jakobson que aponta para a simultaneidade dos traços que caracteriza o fonema. Ao aprofundar seus estudos na fonologia, o autor corrobora sim a tese saussuriana do valor do significante e as diferenças opositivas que determinam a língua, mas renuncia, como diz textualmente, ao caráter linear do significante do signo saussuriano. O autor lança mão de diversos exemplos, entre eles o fato de uma vogal ser, ao mesmo tempo oral, aberta e arredondada. Assim, para 
Jakobson, o fonema é uma entidade complexa: não é o fonema, mas cada uma de suas propriedades distintivas que é uma entidade irredutível e puramente opositiva. (loc.cit.)

Mais ainda: Jakobson considera que o signo linguístico opera em dois eixos: o da simultaneidade e o da sucessividade ${ }^{23}$, inserindo desta forma a prosódia nos estudos da linguagem, e não como propriedade extra ou paralinguística.

Já o questionamento da arbitrariedade do signo nos leva a uma discussão mais delicada. O que Jakobson propõe é considerar, corroborando Benveniste, a ligação entre significado e significante como necessária e não arbitrária. Jakobson argumenta que embora o elo entre as duas faces do signo linguístico seja determinante para que ele funcione como tal, há uma certa motivação de alguns significantes, que só se manifesta nas margens do léxico conceptual, nas palavras expressivas e onomatopéicas (...) (1977, p. 87)

Garcia (1994) investiga em profundidade a arbitrariedade do signo lingüístico e a possibilidade de um simbolismo sonoro, deixando claro que dimensão do termo arbitrariedade está em questão: não a institucionalidade da língua, mas a imotivação do signo. A autora defende a idéia de que existem qualidades intrínsecas do significante (que podem ser naturais, linguísticas ou culturais) que são expressivas e interferem na produção do sentido.

Para sustentar sua tese, Garcia aponta a possibilidade de uma mimese originária entre realidade e signo, mas que a própria constituição do signo, para que funcione estabilizado na língua, trata de barrar, com uma função arbitrante. A valorização da materialidade do significante pode ser considerada suporte que produz em si movimento semiótico, o que contraria o dogma da arbitrariedade do signo lingüístico, segundo a qual o som é irrelevante, afirma a autora. Do ponto de vista da autora, o fato de que a linguagem

\footnotetext{
${ }^{23}$ Eixos que em outros textos serão chamados de eixos paradigmáticos e sintagmáticos ou ainda metafóricos e metonímicos.
} 
seja feita de sons físicos abre-lhe possibilidades expressivas. (...) A matéria, portanto, participa do valor; a matéria integra a estrutura, o sistema. (1994, p.154)

Podemos identificar que quando Garcia fala em matéria, está falando em última instância de corpo, pois é ele que é sensível à matéria. O que é evidente em sua tese não é apenas a discussão da motivação e do gesto mimético que dinamiza a linguagem: é a presença de um sujeito. Vejamos este recorte:

Dizer que a linguagem é somente um sistema de signos arbitrários seria o mesmo que dizer que uma música se reduz a sua partitura: notações convencionais cujos significados (a nota musical) e significantes (o som da nota) compõem um sistema que se define pelas oposições. Mas é muito mais do que isso: é todo este aparato posto em movimento, em ação, dinamizado, provocando com isso sensações, idéias, imagens, intuições, sentimentos. (1994, p. 152)

A aproximação entre o que Garcia expressa e a psicanálise é evidente: no recorte acima, aparece nas entrelinhas a pulsionalidade, a pulsação entre o somático e o mental. Ora, o que é arbitrário no signo é a barra /, que limita a motivação, instaura a exclusão do corpóreo, do material, em nome da permanência do cultural: a língua. Os movimentos pulsionais animam o desejo e provocam incidências de sujeito. A escrita psíquica usa uma folha diferente daquela que Saussure usou no curso de linguística geral. Lembremos: $A$ língua é também comparável a uma folha de papel: o pensamento é o anverso e o som o verso (Saussure, 1970, p. 131). Para falar de subjetividade e linguagem, recorrer a elementos da teoria de Freud e Lacan é poder pensar na folha de papel moebiana, em que as faces não se distinguem a não ser em um ponto dado; a continuidade da faixa nos leva à impossibilidade de decidir. É nesta "folha” que o psíquico escreve. 


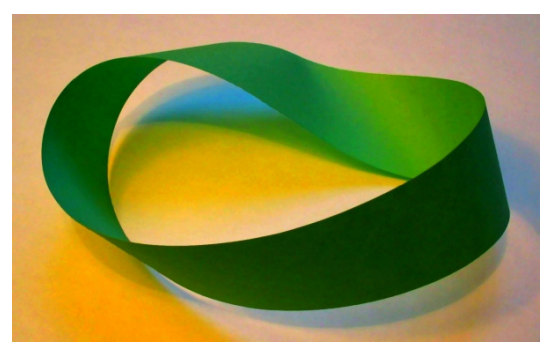

Figura 5 - faixa de moebius

O signo linguístico saussuriano não remete ao sujeito. É da língua que se trata. No entanto, quando se fala em linguagem e em uso da língua, outros elementos sonoros são convocados, ligados muito mais ao corpo e aos sentidos que as palavras tomam, quando em ação. A linguagem comporta elementos enunciativos, como diz Benveniste (1976), que remetem ao sujeito; há uma implicação do corpo, entram em cena os ritmos, os prolongamentos, as repetições, a modalização melódica, os silêncios, efeitos cinestésicos, sinestesia: presença de sujeito. Todo este corpo de traços vai se inscrevendo incessantemente e se faz presente a partir da dinâmica pulsional.

Talvez seja neste sentido que Garcia (1994), com Jakobson (1977) indique o fenômeno de remotivação do signo: alguns signos, algumas formas linguageiras parecem conservar ou recuperar a ligação com a materialidade recalcada. É o caso evidentemente das onomatopéias, da poesia e poderíamos acrescentar os textos, cantigas, parlendas, anedotas que jogam com a sonoridade significante, criando novos sentidos, não expressos pela língua normativa.

Para Foucault (2009, p. 306), a discussão acerca da origem da linguagem, a procura do momento em que o fonema se destacou do ruído é uma busca de sonhadores, já que o surgimento da palavra não está relacionado a um ruído, mas a um processo em que cenas vividas geram um grande ruído repetitivo. 
A palavra não aparece quando cessa o ruído: ela nasce com sua forma entrecortada, com todos os seus múltiplos sentidos, quando os discursos se aglutinaram, se retraíram, comprimidos uns contra os outros, no corte escultural do murmúrio.

Kristeva (1977) chama de polylogue o texto que reúne diferentes modalidades significantes: uma rima-som-voz-escansão, que não é localizável em um ponto, mas dispersa no tecido da linguagem. O texto polylogue faz surgir ritmo, velocidade, pulsionalidade, focaliza um "ser vivente". Nem poesia, nem romance, o texto polylogue remete, através de operações simbólicas (linguísticas) e semióticas (extra-linguísticas), a uma posição enunciativa, revelando o genotexto, aquilo que está além da sequência discursiva lógica.

Tal característica "polilógica" de alguns textos parece ser particularmente invocante/evocante. Não exatamente confortável, este texto provoca o leitor, aguça os sentidos, provoca risos, lapsos e convoca a emergência subjetiva. É o caso da escrita, por exemplo, de Saramago, de Guimarães Rosa. Mas que é também presente nos textos a seguir:

Guando agordei esta banhã Estava gombletamete endupido.

Zaí bra domar ar.

Engontrei um bodão

Gue bensava zer um darize falou:

- Dambém esdou endupido.

Falei:

_ se estamos endupidos

Zó há uma goisa a fazer:

engontrar

um lenço e assoar.

Olivier Douzou, O dariz 2009

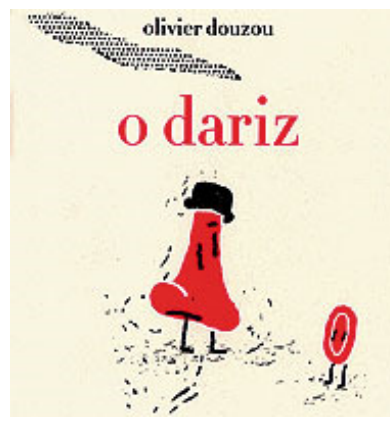

Figura 6 - capa do livro O Dariz 


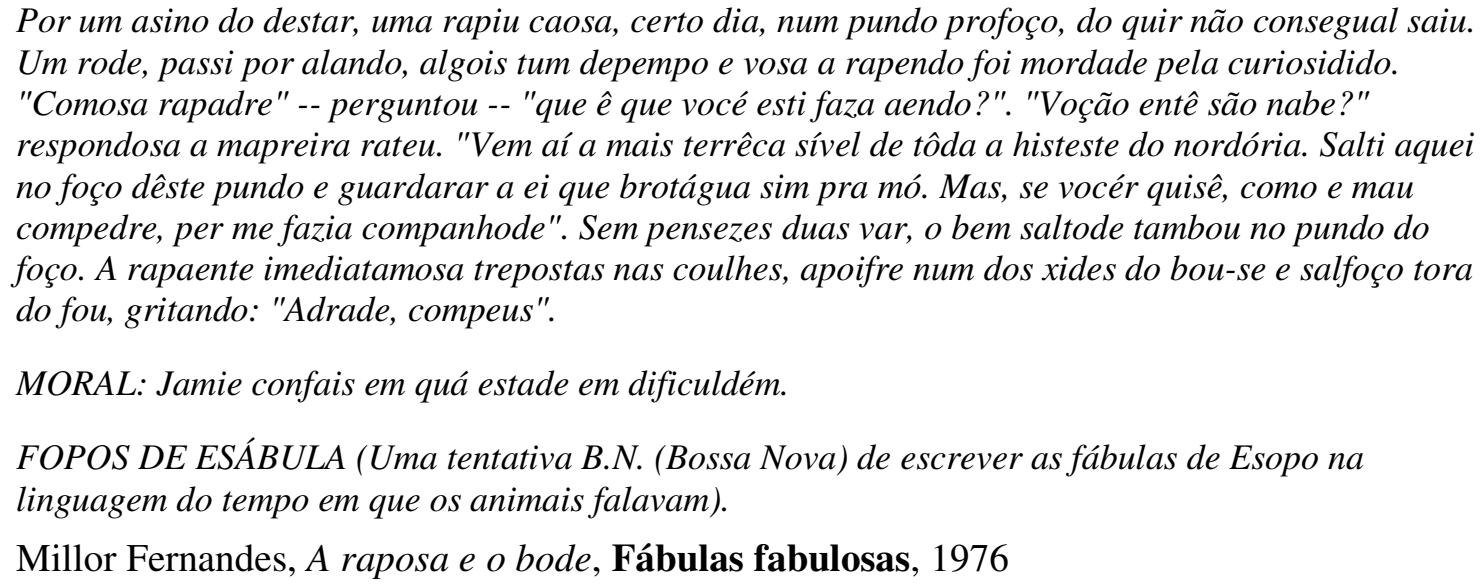
Um rode, passi por alando, algois tum depempo e vosa a rapendo foi mordade pela curiosidido. "Comosa rapadre" -- perguntou -- "que ê que vocé esti faza aendo?". "Voção entê são nabe?" respondosa a mapreira rateu. "Vem aí a mais terrêca sível de tôda a histeste do nordória. Salti aquei no foço dêste pundo e guardarar a ei que brotágua sim pra mó. Mas, se vocér quisê, como e mau compedre, per me fazia companhode". Sem pensezes duas var, o bem saltode tambou no pundo do foço. A rapaente imediatamosa trepostas nas coulhes, apoifre num dos xides do bou-se e salfoço tora do fou, gritando: "Adrade, compeus".

MORAL: Jamie confais em quá estade em dificuldém.

FOPOS DE ESÁBULA (Uma tentativa B.N. (Bossa Nova) de escrever as fábulas de Esopo na linguagem do tempo em que os animais falavam).

Millor Fernandes, A raposa e o bode, Fábulas fabulosas, 1976

Zou meio inglês, meio amerigano. Minha mãe é amerigana e meu bai é inglês. Esdudei em Londres e minha bronúnzia é bridânica.- glara, adé ligeiramende ogsvordoana, a mesma do meu bai. Os americanos muidas vezes vigam zurbresos de ouvir um garodo de onze anos gue vala gomo eu valo.

Martim Amis, Água pesada, p.261)

Nos textos acima fica clara não a subversão da regra da língua, mas uma criação, uma proposta de funcionamento de linguagem, alternativa à língua normativa. As relações entre significantes são apresentadas de modo a esconder/revelar outro texto: aquele que não é visível, mas que está escrito.

Se o texto recebido é a composição dos elementos simbólicos e semióticos, a leitura em voz alta, particularmente nestes textos, pode incidir de maneira a favorecer a emergência do simbólico, a partir do semiótico. Para Kristeva (1977) e Scarpa (1999), na aquisição da linguagem oral os elementos prosódicos (o ritmo, a entonação, a duração dos elementos sonoros) funcionam como primeiros organizadores sintáticos e lexicais. 
A sonoridade do texto, carregada pela voz e pelo corpo, faz ler linhas e entrelinhas; aquilo que não pode ser dito revela ao mesmo tempo o genotexto e a escrita não visível, provocando tanto efeitos enunciativos quanto subjetivos.

A recepção da poesia, para Woolf (2007), é alienante: o impacto da poesia é tão forte e direto que para este momento não há outra sensação senão a do poema em si. (idem, p. 130)

Poderíamos dizer que a subjetividade é efeito de uma escrita psíquica que usa como matéria prima traços que não estão necessariamente associados ao linguístico? Rego (2006) aborda a questão revendo os conceitos de escrita e traço em Freud e Lacan, num movimento que a própria autora chama de extração de uma teoria a partir dos textos psicanalíticos. De acordo com Rego (2006, p. 125), a pulsão se fixa em representações que se articulam antes da palavra e sem a palavra.

A distinção entre o significante da língua e o significante lacaniano é também esclarecedora:

Se o significante lacaniano não pode ser reduzido à palavra, estamos na escrita (psíquica). Representação-palavra e representação-coisa são ambos significantes: um escritural, outro lingüístico, ambos são traços: um é traço de coisa, o outro traço de palavra, sem significado estável próprio. (Rego, 2006, p.125)

Rego chama de escrita aquilo que no presente texto estamos chamando de escrita psíquica. Para a autora, esta escrita é animada pelas pulsões. A partir daí é possível pensar que a subjetividade pode ser convocada pela pulsionalidade invocante, pela voz, o chamado do outro. A presencialidade do outro que conta, que faz traço, não do que se diz, mas de algo que não é possível dizer.

Quando ouço a voz dele me dá uma coisa. Diz uma amiga apaixonada. É isso. As coisas não têm paz. Lembra Arnaldo Antunes (1996). Uma coisa inominável, que Lacan 
associa ao Das Ding freudiano, ao objeto perdido, ao objeto a, ao traço unário. (Miller, $1989) .^{24}$

No seminário IX, lição 4, Lacan discute o estatuto do significante. O signo representa alguma coisa para alguém; Já o significante manifesta a presença da diferença. (2003, p.63). O significante é vazio; constitui uma possibilidade de ser de um traço. E aqui, a psicanálise caminha com Jakobson, para quem as propriedades distintivas dos significantes desempenham uma função significativa, mas são vazias de significação em si próprias. Nem uma qualidade distintiva tomada em si própria nem um feixe de qualidades distintivas, ou seja, um fonema, tomado em si próprio, significa coisa nenhuma. (1977, p.87)

Vejamos este interessante trecho, em que fica evidente a aproximação que podemos fazer com as noções de traço advindas dos textos lacanianos:

Ora, esse vazio tem de ser preenchido. A intimidade dos laços entre os sons e o sentido da palavra dá vontade aos sujeitos falantes de completarem a relação externa com uma relação interna, a contigüidade com uma semelhança, com um rudimento de caracter visual. Em virtude das leis neuropsicológicas da sinestesia, as oposições fônicas podem chegar a evocar relações com as sensações musicais, cromáticas, olfativas, táteis etc. (Jakobson, 1977, p. 87, grifo nosso)

Andre Lew (1989) aborda aspectos do estatuto da voz na teoria psicanalítica. Para este autor, a voz não é para ser compreendida; isso não é para compreender. A voz pode funcionar como uma escrita, não a partir de imagens como o sonho, mas a partir de material sonoro, vocal. A significância da voz depende da articulação significante nos eixos de contigüidade e simultaneidade, diz Lew (p.7), lembrando Jakobson.

A partir daí podemos pensar que a voz carrega são traços dos fonemas e traços da diferença na articulação de contiguidade, o que inclui a musicalidade da voz na fala. A voz faz ressoar a gramática pessoal de cada um. Para Lew a voz é significante porque faz ouvir bem mais que os fonemas na língua. ( p.5).

\footnotetext{
${ }^{24}$ Este tema será abordado em maior profundidade no próximo capítulo, em que tomaremos a cena de leitura em
} 
Assim como Shaffer procura agregar à arte elementos sonoros que ficavam à margem do sistema de escritura musical, é possível pensar em elementos paralinguísticos como também codeterminantes do sentido criado pela linguagem verbal. $\mathrm{O}$ fato do significante saussuriano se constituir a partir da fonologia não implica necessariamente que não haja outros significantes - fonéticos, rítmicos, melódicos, de timbre - incidindo na linguagem verbal. A questão que se toca aqui é o fato de que o modelo de Saussure ainda não foi suplantado por alguma modelo que contemple, na linguística, a dimensão extrafonética da linguagem.

Abaurre (2006) afirma que este fato está ligado ao sistema de escrita que utilizamos. A autora evoca situações-limite, como as que são frequentes na aquisição da linguagem - mas também poderíamos citar a poesia e os "textos polilógicos" de Julia Kristeva- que apontam para o papel estruturante dos fenômenos prosódicos na relação entre o sujeito e a linguagem.Para Abaurre, a utilização de um sistema de escrita de base alfabética privilegia os segmentos, excluindo a representação do plano prosódico.

Também Fontaine (2002) chama atenção para o valor sonoro das palavras, que está além da possibilidade de escrita.

Parece possível fazer uma distinção entre a língua, tal como a escrita se esforça por fazer sua notação, e essa outra coisa que lhe escapa, de um certo modo, atribuida/referida localmente aos acentos (agudos, graves, circunflexos, de exclamação, etc.), mas que os ultrapassa grandemente. Algo que tem a ver com o que se poderia designar por um termo como "tom" no sentido em que, como nossa expressão de uso a designa: uma coisa pode ser dita em todos os tons. (Fontaine, 2002, p.165)

A partir daí é possível retomar a noção de voz na concepção lacaniana: $a$ voz é exatamente o que não se pode dizer (Miller, 1989). O desenvolvimento dos estudos neurofisiológicos da voz nos permite ver a voz, analisá-la em seu espectro físico. Mas ela 
ainda é resto, não há como descrevê-la sem apelar para os sentidos: clara, escura, fria, doce etc.

Tomamos aqui a sonoridade da linguagem e da língua para além de seus aspectos definidores do signo linguístico, já que percebemos que os tons revelados na atividade discursiva podem significar um sujeito. O significante, nesta medida, não está amarrado ao signo saussuriano. Como comenta Alfredo Jerusalinsky (2003), um sotaque, uma musicalidade, um traço não linguístico podem funcionar como significantes. Nas palavras do autor:

Assim como Lacan chama atenção sobre as figuras da retórica como lugar de trânsito das formações do inconsciente, podemos aportar que as formações do inconsciente também transitam pela prosódia e acentuação, tendo então as suas conseqüências na ortografia. ( 2003, p. 26, grifo nosso)

Aqui, estamos prontos a responder à pergunta colocada no final do capítulo anterior. Barthes utiliza a escrita em voz alta como fonética: talvez justamente para se referir a um traço que não é da língua, que sobra da operação de recalque. Por isso uma escrita que procura os incidentes pulsionais, como diz o autor.

As características sonoras que não são descritas pela fonologia linear, como uma rouquidão, um sotaque, uma distorção articulatória, não dizem respeito à língua. Mas dizem respeito ao sujeito, como vimos na idéia dos traços acústicos do inconsciente e na valorização da imagem sonora na atividade de simbolizar, em Freud, assim como no estatuto da sonoridade não linear na pulsão invocante.

Trago aqui um recorte clínico. Tiago, um menino de três anos, compareceu para atendimento fonoaudiológico, pois a família de Tiago foi orientada a procurar avaliação fonoaudiológica, já que o menino apresentava atraso na fala e muitas trocas, sendo dificilmente entendido por outras crianças e adultos. Tiago é um dos meninos de um trio de gêmeos; sobre seus outros irmãos gêmeos, um menino e uma menina, não havia queixas de linguagem. 
$\mathrm{Na}$ entrevista com a mãe, constatei que o que motiva realmente a família não era a fala pouca e difícil, mas uma característica peculiar do modo como Thiago falava, que incomodava muito os pais, em especial o pai: a interposição de língua entre os dentes ao articular /s/ e /z/. Também conhecido como ceceio - popularmente língua presa -, esta forma de articulação não interfere na língua, pois há uma distorção do som, mas não há alteração do padrão fonológico, apenas fonético. No entanto, o diagnóstico, a determinação deste modo de falar como patológico é feita a partir dos seis ou sete anos de idade, pois as mudanças do ambiente oral são muitas até esta idade; as condições de crescimento craniofacial, dentição, interação entre respiração e mastigação organizam atividade muscular e cinestésica que condicionam padrões de articulação da fala ${ }^{25}$. Além do mais, a patologização do ceceio está associada a uma condição de sofrimento da criança e, portanto necessidade de modificação do padrão de fala.

Estive com Tiago sozinho e na companhia dos irmãos; ele se apresentava como um menino ativo, com reais dificuldades de interação verbal: falava muito pouco, palavras isoladas com um grau importante de ininteligibilidade; usava constantemente gestos indicativos ao solicitar e responder e preferia agir ao falar. No entanto, seu irmão também apresentava dificuldades de expressão, diferentemente da irmã, que se mostrava falante, fluente e, na interação com os irmãos, era normalmente quem organizava as atividades, funcionando como uma espécie de intérprete da interação dos irmãos com adultos.

O que me intrigava neste atendimento: Por que a queixa da família era ceceio se a criança mostrava claras dificuldades de linguagem? Por que só Tiago veio para o atendimento se o irmão também demonstrava dificuldades de linguagem? Insisti na presença do pai, até então ausente nas sessões, por sempre justificados motivos.

\footnotetext{
${ }^{25}$ É possível, no entanto, realizar ações preventivas em relação às alterações fonéticas da fala, em situações nas quais a avaliação clínica apresenta fortes indícios de alterações de fala, quando já há diagnóstico de alterações de motricidade oral, por exemplo.
} 
A sessão com pai e mãe foi bastante esclarecedora: logo ao encontrá-lo me dei conta de que Tiago é o único dos três que se parece (fisicamente) com o pai. No desenrolar da sessão, o pai relatou por diversas vezes o medo de que seu filho mantivesse a forma de falar que ele, pai, identificava em "homossexuais" ou "sindicalistas": o ceceio, a "língua presa". Ficou claro então, porque tratar o ceceio e porque tratar Tiago. O som distorcido passa a ser uma ameaça familiar, especialmente ao pai e suas projeções em relação ao filho. Som aqui é significante. Não em termos saussurianos, mas com certeza pensando com Lacan.

\subsection{Antes de existir o alfabeto existia a voz}

A voz existe desde sempre, antes ainda de a linguagem ter início e se articular em palavras para transmitir mensagens sob a forma de enunciados verbais, isto é, como potencialidade de significação, e vibra como um indistinto fluxo de vitalidade, como um confuso impulso para o querer-dizer, para o exprimir, ou seja, para o existir. Bologna, C. Voz, 1987 , p. 58

Caminhando em nossa reflexão sobre sonoridade, a constituição subjetiva e a apropriação da linguagem, identificamos autores que focalizam, nos jogos maternantes em torno da voz, as origens do laço com o outro: a partir do corpo e do chamado. Este aspecto essencialmente corporal e dialógico da voz interessa à psicanálise, como podemos testemunhar nos trabalhos de Dideir-Weil (1999), Laznik-Pennot (2000) Vorcaro (2001) e Jerusalinsky (2006), que abordam diferentes aspectos da pulsão invocante.

A vocação para tornar-se humano nos é originalmente transmitida por uma voz que não nos passa a fala sem nos passar, ao mesmo tempo, sua música: a música desta "sonata materna” é recebida pelo bebê como um canto que, de saída, transmite uma dupla vocação: está ouvindo a continuidade musical de minhas vogais e a descontinuidade significante das minhas consoantes? (Didier-Weil 1999, p. 9)

Essa dupla vocação, de que nos fala o autor, dá conta de colocar na voz/fala da maternagem algo de corpo, de gozo e ao mesmo tempo de corte, de interrupção do corpo, de 
recalque. Nota-se aí a inscrição da humanização: corpo funcionando pulsionalmente - origem do desejo para Freud (in Roza, 1988) - mas interditado em seu gozo pleno.

$\mathrm{Na}$ fronteira entre o somático e o psíquico, a pulsão representa a força impulsionadora da libido. Freud fala da não-coincidência entre as zonas erógenas e o funcionamento biológico, já que a pulsão se constitui a partir do organismo.

É a partir de Lacan que a voz, na psicanálise, passa a assumir um estatuto pulsional. De acordo com Kaufmann (1996), a originalidade de Lacan no trato com as pulsões está em “abrir" as zonas erógenas, de maneira a caracterizá-las como estrutura de borda. Podemos dizer, grosso modo, que o que funciona como pulsão sempre se caracteriza por orificios nos quais se encontra a estrutura de borda. (Lacan, 2008, p. 223)

Desta forma, é o vazio que é contornado pela montagem pulsional, para tentar delimitar algo a que de verdade não se tem acesso, o objeto a, algo que sempre falta e sobra na experiência de prazer.

Gullar $^{26}$, em não-coisa, fala da poesia como algo do indizível, algo que não tem nada dentro:

O que o poeta quer dizer No discurso não cabe E se o diz é pra saber $O$ que ainda não sabe... Toda coisa tem peso Uma noite em seu centro. O poema é uma coisa Que não tem nada dentro,

A não ser o ressoar De uma imprecisa voz -essa voz somos nós.

\footnotetext{
${ }^{26}$ Bosi, Ferreira Gullar: seleção ,2004.p.239
} 
A voz, produzida na laringe, a partir da movimentação das pregas vocais, é corpo que chama, portanto invocante. Curiosamente, a anatomia da glote - espaço em que se situam as pregas vocais - permite visualizar o que de borda há na pulsão invocante:

ilustração da esquerda representa as pregas vocais durante a respiração; a ilustração da direita
representa as pregas vocais durante a fonação, produção de som a partir da vibração das
pregas. Ilustração disponível em www.brasilfonoaudiologia.com.br/images/ consultado em $08 / 12 / 2008$

Laznik-Penot (2000) estuda os traços acústicos nas primeiras relações mãe/bebê e como a voz atua com estatuto de constituinte pulsional. A autora argumenta que os traços acústicos são registrados no polo alucinatório da satisfação, além dos traços visuais. Deste modo, a prosódia pode não apenas estruturar o caminho para que a criança acesse a língua, como defende Kristeva (1977), mas também funciona como estruturante da escrita psíquica.

Para Manuel Bandeira ${ }^{27}$, o simbolismo sonoro singular, os traços inscritos na infância, convocam sentidos:

Murmúrio d'água, és tão suave a meus ouvidos...

Faz tanto bem à minha dor teu refrigério!

Nem sei passar sem teu murmúrio a meus ouvidos, Sem teu suave, teu afável refrigério

Água de fonte...água de oceano...água de pranto... Água de rio... Água de chuva, água cantante das lavadas... Têm para mim, todas, consolos de acalanto, A que sorrio...

A que sorri a minha cínica descrença.

A que sorri o meu opróbrio de viver.

\footnotetext{
${ }^{27}$ JARDIM, M.(org.) -Manuel Bandeira: uma antologia poética., pp. 55-56
} 
A que sorri o mais profundo desencanto

Do mais profundo e mais recôndito em meu ser!

Sorriem como aqueles cegos de nascença

Aos quais Jesus de súbito fazia ver...

A minha mãe ouvi dizer que era minh'ama

Tranqüila e mansa.

Talvez ouvi, quando criança,

Cantigas tristes que cantou à minha cama.

Talvez por isso eu me comova a aquela mágoa.

Talvez por isso eu me comova tanto à mágoa

Do teu rumor, murmúrio d'água...

A meiga e triste rapariga

Punha talvez nessa cantiga

A sua dor e mais a dor de sua raça...

Pobre mulher, sombria filha da desgraça!

- Murmúrio d'água, és a cantiga de minh'alma

Também Julieta Jerusalinsky (2006) sustenta a idéia de que as vocalizações do bebê e a fala da mãe instalam um jogo erógeno no laço com o outro. Não apenas a voz, como fonação, defende a autora, mas também os deslizamentos melódicos, os traços de ritmos e silêncios que comporiam uma verdadeira conversa sonora. As brincadeiras sonoras representariam a marca do outro por meio das relações de corte, do inesperado, da surpresa, que deslocariam o ritmo orgânico da criança.

Carregando muito mais do que a linearidade do significante saussuriano, ou seja, mais do que a transmissão do código, da língua, a voz materna põe em jogo tempo, ritmo, melodia, harmonia, timbre; o som ofertado à criança não é o som da língua, em seu recorte fonológico, mas o som no corpo, motivado por memórias e motivando inscrições na criança e mesmo, por que não, reinscrições na constituição materna. A criança, por sua vez, produz sons, a princípio em um exercício perceptivo/motor/sonoro que envolve o balbucio, mas que também releva o caminho do laço com a mãe. Nas palavras de Julieta Jerusalinsky as produções vocais da criança variam em intensidade, ritmo e entoação, a partir de um jogo erógeno no laço com o outro. (2006, p. 211) 
O jogo de que fala Jerusalinsky envolve a relação entre a mãe e bebê e as sonoridades é apontado por Vorcaro (2001, p.4), que valoriza a questão do ritmo no jogo de troca de posições nas conversas maternantes:

É o que podemos constatar antes de um domínio da língua, no jogo infantil em que a criança é embalada pelo adulto até ser surpreendida por uma diferença rítmica em geral acompanhada de uma extensão ou de uma escansão sonora e corporal. O que opera nesse jogo lingüístico do embalar andante é que se puxa uma fralda sonora. Fralda sonora que permite entreouvir um traço de presença subjetiva: a criança espera antecipadamente a surpresa de uma descontinuidade. Essa defasagem demarca um lapso no qual a criança se engaja em re-experimentá-lo no jogo do andamento definido pela articulação sonora.

Mais adiante, neste mesmo texto, Vorcaro ainda nos fala dos jogos próprios da tradição oral em que ritmos e repetições dão o tom. Para a autora, nas parlendas (por exemplo, "uni du ni tê”), o sentido é constituído pelas repetições prosódicas, organizando no jogo algo já experimentado no corpo.

Sabina Spielrein, psicanalista contemporânea de Freud, foi a primeira a tentar articular linguagem e pulsões, examinando - de um ponto de vista analítico -, os fenômenos psico-fonemáticos (Cromberg, 2008) ${ }^{28}$. Em 1922, durante o VI Congresso Internacional de Psicanálise - o mesmo em que Freud leu seu texto Mais além do princípio do prazer, Spielrein torna público seu texto intitulado As origens das palavras infantis Papai e Mamãe (Cromberg, 2008). Neste texto, Spielrein defende uma intensa relação entre corpo, pulsões, prazer e surgimento da linguagem. Mais ainda, a autora argumenta em favor de uma forte relação entre elementos melódicos e rítmicos e conteúdos psíquicos.

Quando nós adultos, falamos em linguagem, pensamos no conteúdo da palavra, e não percebemos o papel desempenhado, mesmo em textos escritos, por recursos do domínio da linguagem rítmica e melódica, como pontos de exclamação, pontos de interrogação etc. [....] a linguagem verbal é apenas uma parcela da linguagem falada e, paralelamente a ela, existem

\footnotetext{
28 Embora interesse particularmente às reflexões sobre linguagem e subjetividade, a obra de Spielrein permaneceu sem voz durante décadas. Este "soterramento histórico" é comentado por Renata Cromberg, 2008, que em sua tese de doutorado, além de discutir as razões para este esquecimento, oferece uma boa introdução à leitura da obra de Spierlein.
} 
outras linguagens, a visual, a dos gestos, a do tato, a das entonações. A melodia e o conteúdo da linguagem predominam enquanto servem para a comunicação, enquanto linguagem social e de constituição de um si para outro si. (Spielrein, 1922 citado por Cromberg, 2008, p. 275)

Para Spielrein, a linguagem musical - ritmos e deslizamentos melódicos antecede a linguagem verbal. $\mathrm{O}$ choro da criança é o exemplo clássico (como vimos mais acima, com Jerusalinsky, 2006). A originalidade de Spielrein, no entanto, não está em dimensionar a prosódia da linguagem, mas observar justamente o surgimento dos primeiros fonemas e estabelecer uma associação entre corpo e produção fonética.

Observando que na maioria das línguas, a palavra mamãe é representada pelo fonema nasal $/ \mathrm{m} /$ e a palavra papai envolve bilabiais $/ \mathrm{p} /$ ou $/ \mathrm{b} /$ ou mesmo dentais $/ \mathrm{t} / \mathrm{ou} / \mathrm{d}$, Spielrein desenvolve um argumento que liga as primeiras experiências corporais do bebê ao prazer e à sonoridade possível.

De acordo com as observações da psicanalista, o bebê ao balbuciar percorre uma crescente complexidade articulatória, que vai da emissão de vogais isoladas - a voz sem obstáculos - à associação de vogais/consoantes. O bebê, ao mamar, sacia sua fome, experimenta prazer. Logo após a mamada, se colocado no berço, o pequeno mantém os movimentos de sucção e agrega uma vocalização, produzindo sílabas "mö-mö-mö e "pó-pöpö”.

Ora, as nasais estão evidentemente "ensaiando" a palavra mamãe e as plosivas,como papai. Esta observação não é novidade no campo da aquisição de linguagem e da linguística e remete imediatamente aos trabalhos de Jakobson, especialmente Why mama and papa? A noção de Universais Lingüísticos, introduzida pelo autor, procurava justamente argumentar por uma não coincidência entre as morfologias muito semelhantes que as palavras mamãe e papai podiam se apresentar em diferentes línguas. O que diferencia o 
trabalho de Spielrein do de Jakobson é a dimensão pulsional que a psicanalista dá às observações, enquanto o linguista se concentra na articulação das dimensões fonéticofonológica e social.

Para Spielrein, a mamada, o movimento de sucção, está associado à movimentação dos lábios unidos, como na produção do $/ \mathrm{m} /$; ao se saciar, a criança brinca com o peito da mãe, em movimentos de prender e largar, promovidos pela explosão dos lábios, como em /p/ e /b/. Seguindo este raciocínio, a emissão de silabas com nasais remeteria a um movimento alucinatório da mamada, um chamado, na presença do desprazer, da fome. Um chamado de mãe.

A criança desejará naturalmente reencontrar estas sensações; instintivamente, ela desejará colocar sua boca em uma posição que produz os sons evocados. A ligação entre as sílabas "mö-mö" $e$ as sensações correspondentes se torna cada vez mais íntima e se torna uma constante; a criança procurará produzir esses sons para provocar em si o grupo de sensações esperadas e familiares, porque certos sons são ligados a conteúdos psíquicos já determinados, às sensações, talvez já às representações, nós podemos neste ponto, já falar em "palavras" que mostram esses conteúdos, ou seja, os significam (Spielrein, 1922 citado por Cromberg, 2008, p. 284).

Chamar a mãe é portanto chamar aconchego, ajuda. Talvez seja por isso que meu pai, em recente episódio de doença, aos 70 anos, chamou, em semiconsciência, por sua mãe. Ou uma conhecida, artista plástica, também com cerca de 70 anos, comentando a saudade da mãe, morta há cinco anos, revela-me que sente falta da mãe, mas sente muita falta de chamar por ela, de dizer "mãe".

O chamado da voz escapa ao corpo, mas é possível não deixá-la escapar: a produção da voz com lábios cerrados produz uma sonoridade do mamar, que também é a expressão do prazer gustativo: Huumm!

Talvez esteja nesta relação mamada/nasalização/prazer as raízes do som da meditação indiana "Om”. Na tradição oriental, o Mantra "Om" é entoado três vezes sempre 
que há uma necessidade de introspecção ou concentração. O mantra é composto por três sons que se seguem: /a/, /u/ e /m, observando que o nasal é prolongado até que o ar da fonação se esgote, então se segue um silêncio, novamente quebrado pela vogal. (Stoddart, 2005)

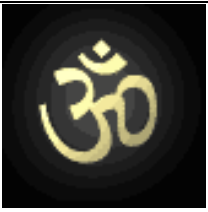

Figura 8 - "OM" é o som mais sagrado para os hindus e é a semente de todos os mantras. O "3" representa a trindade dos deuses da criação, da preservação e da destruição. O "0" é o silêncio de alcançar Deus.

Corrado Bologna, na Enciclopédia Einaudi, reflete a partir da sílaba mística da tradição indiana: o som traduz a relação que existe entre pensamento e imaginação. A sílaba “om" produzida prolongada e repetidamente vitaliza os canais de emissão do sopro vital. Esta sílaba, segundo os hindus, serve para exprimir a sonoridade originária, vital, criadora. Só é possível perceber tal som eterno e primordial tapando o nariz e as orelhas, abstraindo-se dos sons e das palavras "terrestres"; deixando ressoar a voz nos meandros do corpo e nas cavernas do espírito (Enciclopédia Einaudi: Voz; Bologna 1987, p.61).

O mantra "om" procura restaurar a energia primordial; simboliza também a unidade. Não teríamos aí uma metáfora interessante da unidade perdida, primária, de que nos fala a psicanálise?

É possível perceber, portanto, que a vocalidade, a experimentação sonora melódica e rítmica - marca primordialmente a constituição subjetiva. É a partir da relação do corpo do bebê e da mãe - instanciados sonoramente - que será possível edificar o jogo de dar e receber, constituir sujeito e outro. A diferença rítmica, apontada por Vorcaro (2001), obriga a criança a experimentar um igual-diferente: a impossibilidade de repetir o mesmo já vivido: o outro oferece esta marca no corpo da criança. Marca necessária para a entrada na linguagem: alucinação da satisfação, da busca pela repetição do prazer original. Esta 
experiência inicial, esse germe dialógico, está implicado na organização pulsional e nas formas como se movimentará o desejo.

A impossibilidade de repetir o mesmo, que está ligado à falta, um dos conceitos centrais da psicanálise freudiana, está já anunciada no Projeto para uma Psicologia Científica (Freud, 1895). Para que se reconheça a repetição como uma reapresentação de algo já-visto, é necessário que se fale em memória. Para Freud, a memória é intervalar, o que significa dizer que não se trata de um acúmulo quantitativo de informação, mas em uma marca qualitativa entre as representações.

Ora, para o bebê é a voz, seu ritmo, suas intensidades, sua melodia, que garante a sobrevivência, já que representa tanto a via de apelo ao outro, de expressão do stress biológico, como o caminho de apaziguamento e ordenação do caos de sensações. O que se pode ver, então, é que as repetições sonorizadas são constitutivas da estruturação de um corpo e estão intimamente ligadas às sensações de prazer e desprazer.

Sonia Salmeron (1996) utiliza o termo "eu sonoro", ou "ego sonoro" (Moi sonore, em francês) para dar conta de referir o resultado do depósito de diferentes identificações que se articulam durante a infância e que irão organizar parte das identificações futuras. A partir da observação clínica em que seus pacientes colocam em cena impressões sobre o valor da entonação e da musicalidade da voz, Salmeron teoriza a incorporação do objeto que ela chama de "bolha sonora".

Para esta autora, toda sonoridade percebida pelo bebê - as vozes humanas, a voz da mãe, os batimentos cardíacos próprios e os da mãe - são inscritos de modo a formar uma rede de ressonância egóica. Estas incorporações são defensivas ao vazio sonoro, ao silêncio que é imposto à criança no evento de seu nascimento: cessa um mundo sonoro intra-uterino. $\mathrm{O}$ "eu sonoro" comporta uma trama sonora, aberta, que faz emergir processos identificatórios nas relações intersubjetivas. 
Podemos pensar, a partir do exposto até aqui, que as marcas sonoras não linguísticas são fundamentais para que a criança se enlace com o outro para então apropriarse da linguagem. Como a fisiologia nos mostra (Belau, 1995), assim como a impressão digital, a voz é única para cada indivíduo: ela é ao mesmo tempo o anúncio do desprazer - o grito - e o lugar do aconchego - o canto -, trilhados de maneira absolutamente singular desde os primórdios da vida de cada um.

É curioso notar que muitos jogos infantis - brincos linguageiros, como aponta Belintane (2006), a poesia, a literatura de tradição oral e grande parte da literatura infantil contemporânea - estruturam-se a partir de elementos de repetição.

Havelock (1996) indica que a poesia oral na Grécia antiga, antes da apropriação da escrita, servia não apenas ao prazer e à diversão, mas antes de tudo à estruturação de um corpo de discurso social, moral e ético, que conduziria a sociedade. Na ausência de uma forma de registro mais permanente - como a escrita - , era preciso garantir a permanência deste corpo discursivo pela memorização. E a maneira, eficiente, que os gregos encontraram foi a associação do discurso ao corpo. A convocação de uma pulsionalidade no discurso garantiria a permanência na memória; a associação do texto a prazeres básicos, sensuais, retomando prazeres ligados ao sexo e à alimentação possibilitou, na emergência do corpo, uma memória. A substituição da Musa (inspiração da oralidade poética) pela escrita, pode ter significado, como aponta Havelock, mais do que o advento de uma técnica superior, mas um instrumento político para destituir uma ordem social.

O que Havelock mostra é que foi exatamente à função didática da poética que Platão se opôs. Se os ensinamentos de Platão foram organizados em prosa não foi ao acaso ou graças a um espírito linguisticamente inovador, mas, sustenta o autor, traduzia uma maneira de apagamento da tradição anterior, uma substituição ligada antes ao poder de controlar e implantar um novo sistema social do que discursivo. 
Seria o advento do platonismo, ou seja, o aparecimento de um vasto corpo de discurso escrito em prosa, um sinal que anunciava que a oralidade grega estava a ceder terreno à literacia e que um estado de espírito oral estava a ser substituído por outro letrado? Uma substituição que o gênio Platão intuitivamente reconheceu? (Havelock, 1996, p.18-19)

Desta forma, antes de pensar as técnicas mnemônicas da oralidade como uma ausência de recalque, é importante destituir o espírito de conceitos prévios e admitir as peripécias mnemônicas da oralidade como um recurso eficiente para garantir a Lei. Lacan nos diz que a função do nome do pai é unir o desejo à lei (Rego, 2006). Que melhor recurso para garantir as leis sociais do que associá-las à repetição, ao ritmo, ao corpo, ativando o que de básico nos remete a pulsão: a fome e o amor?

Neste sentido, e também com Vorcaro (2001), Kristeva (1977) fala da voz materna como nome do pai: se a voz materna é invocante e pulsional, se traz consigo uma convocação do corpo, ela também desliza e flui a partir de um outro: que impõe ritmos e percursos melódicos. Essa dupla dimensão da voz, ao mesmo tempo invocante e castradora, pode estar no centro do sucesso da poesia como recurso mnêmico, na origem dos brincos linguageiros tão comuns na infância e, por que não, no encantamento que alguns textos da literatura infantil provocam.

Lemos (2000) sugere que haja semelhança entre o paralelismo na produção de crianças no processo de aquisição da linguagem e o paralelismo na poesia. A autora lembra, com Jakobson $(1973 ; 1960)$, que o verso (versus) indica justamente um movimento de retroação, distintamente de prosa (oratio proversa), que indica um movimento pra frente. Este trabalho do poético, de reapresentação do mesmo, é tomado como uma das marcas da poesia, independentemente do período ou escola literária, como exemplifica Lemos (2000.p. 9), das cantigas de Martin Codax no sec. XIII a Carlos Drummond de Andrade. 
O que está em causa na rima, ou nos paralelismos poéticos, é o retorno de uma sonoridade esperada, anunciada pela métrica, pelo ritmo - e o comparecimento de uma repetição quase igual. Ora, é esse quase, essa diferença entre um verso e outro, entre uma linha e outra, que anuncia uma alteridade, que faz o sentido da memória, como vimos em Freud. E daí a garantia da memorização pela poesia e do regozijo que se experimenta ao ler ou falar versos, brincos, trocadilhos, trava-línguas.

Belintane (2008) observa que existe um percurso matriciado pela voz parental, do bebê à criança em idade escolar, que inclui justamente estes textos advindos da tradição oral; textos polylogue, nos termos de Julia Kristeva. O autor identifica basicamente dois modos discursivos em que a criança é enredada pela linguagem:

(1) um modo mais direto, prosaico, modo dos afazeres cotidianos, muito marcado pelos imperativos afirmativo e negativo; (2) outro mais catártico, cativante, convocante, no qual podemos incluir o manhês, as cantigas, os brincos, as parlendas, as mnemonias, as adivinhas e outros tipos de textos que parecem mais compromissados com a "lalangue" do que com a "langue". (Belintane, 2008, p.17)

Para o autor, o segundo modo de palavrear pode funcionar de maneira interessante, imbricado na fala cotidiana, e possibilita à criança operações intertextuais e jogos de criação inusitados e singulares: uma subjetividade de entre-textos pontua a língua, elaborando sulcamentos de escrita muito próximos ao modo alfabético de fazer texto (2008:18).

Nesta direção, encontramos também Abaurre (2006), que embora não convoque a dimensão subjetivante das brincadeiras sonoras da infância, reconhece nestas um modo de operação linguística que valoriza a sonoridade e a percepção da constituição silábica, elemento operacional do domínio da técnica alfabética de escrita.

Quem não se lembra, por exemplo, de brincadeiras em que uma certa criança, escolhida para executar determinada tarefa, acabava indicada pela sílaba final de um enunciado segmentado como mi-nha-mãe-man-oudi-zer-pra-eu-ti-rar-es-si-da-qui... ( p. 227) 
$\mathrm{Na}$ literatura infantil da atualidade (na moderna literatura, no temos de Bajard, 2007), principalmente a partir dos anos 1980, é forte a presença de textos que brincam sonoramente ou com elementos de repetição. São esses os textos que mais encantam as crianças. O apelo poético, rítmico e melódico, mnemônico, corporal, convoca a presença da criança com seu corpo.

Vejamos alguns exemplos:

Um ratinho foi passear na floresta escura.

A raposa viu o ratinho e o achou apetitoso.

- Aonde você vai?- perguntou a raposa, com brandura.

Venha almoçar comigo, faço um almoço gostoso.

- Quanta gentileza, raposa, mas não posso aceitar

“Já marquei com um Grúfalo para almoçar.” (...)

E lá se foi o ratinho, caminhando pela floresta.

Uma coruja viu o ratinho que lhe pareceu apetitoso.

- Aonde você vai, ratinho mimoso?

Venha lanchar na minha casa, vai ser uma festa!

- Muito obrigado coruja, mas não posso aceitar.

Vou me encontrar com um Grúfalo para lanchar

Julia Donaldson e Axel Scheffler., Grúfalo, 2002.

Era uma vez uma casa sonolenta, onde todos viviam dormindo.

Nessa casa tinha uma cama, uma cama aconchegante, numa casa sonolenta, onde todos viviam dormindo.

"Nessa cama tinha uma avó, uma avó roncando, numa cama aconchegante, numa casa sonolenta, onde todos viviam dormindo".

Audrey Wood e Don Wood. A casa sonolenta, 2002

Nestes textos, assim como nas brincadeiras de que nos falam Vorcaro, Belintane e Abaurre, há uma convocação da sonoridade, uma repetição que joga para trás, para a recuperação de um primeiro momento. Esta convocação nos lembra o diálogo maternante de 
que nos falam também Vorcaro e Jerusalinsky, na busca de uma sonoridade primordial apontada por Spielrein.

A partir daí esboça-se a presença de um corpo: corpo sonoro, inaugurado pelas primeiras relações com o outro, com o prazer, com o desprazer. Corpo dinâmico, já que vivo. Nele se inscrevem incessantemente os traços acústicos e cinestésicos que convocam outros traços, de naturezas diversas, articulando linguagem, e portanto sujeito.

A escritora Ana Maria Machado, em entrevista à Revista da Cultura, quando perguntada sobre qual a palavra mais bonita da língua portuguesa, responde: Alarido. Não pelo significado, eu detesto barulho, mas pelo som. (Revista da Livraria Cultura, 2009, p.06) Um som que não quer dizer nada, mas que é expressivo.

O corpo sonoro não se confunde com o organismo, com a memória auditiva ou cinestésica; trata-se de um conjunto pulsante, um conjunto moebiano - como sugere Belintane, que faz parte de nossa constituição imaginária: ao mesmo tempo em que se inscreve simbolicamente, noutros momentos é um sopro do real, que nos remete a um espaço sem tempo e sem palavras - um silêncio sonoro que nos faz sentir diferente, sem deixar de ser o mesmo.

A leitura em voz alta mobiliza o corpo sonoro, convoca a singularidade daquele que lê e invoca a presença do outro e do Outro. Mesmo sob tutela da língua, tal prática abre frestas para que se possa escrever em voz alta: a voz como escrito permite a emergência de um sujeito leitor-escritor.

Contudo, há algo além da voz na leitura em voz alta. Outros elementos compõem a cena de leitura: o texto e o olhar. É o que veremos no próximo capítulo. 


\title{
Capítulo 4: A Cena da leitura em voz alta
}

\begin{abstract}
Noutra noite, ao assistir ao filme de Antonioni sobre a China, experimentei de repente, na virada de uma seqüencia, o rumor da língua: numa rua de aldeia, algumas crianças, encostadas a um muro, lêem em voz alta, cada um pra si, todos juntos, um livro diferente; aquilo rumorava da melhor maneira, como uma máquina que funcionasse bem; o sentido era para mim duplamente impenetrável, por desconhecimento do chinês e pelo emaranhamento dessas leituras simultâneas; mas eu ouvia, numa espécie de percepção alucinada, tão intensamente recebia ela toda a sutileza da cena, eu ouvia a música, o sopro, a tensão, a aplicação, enfim, algo como uma meta. Quê! Basta falarem todos juntos para fazer rumorejar a língua, da maneira rara, impregnada de gozo, de que se acabou de falar? De jeito nenhum, claro; para a cena sonora é preciso uma erótica (no sentido mais amplo do termo), o impulso, ou a descoberta, ou o que era trazido justamente pelo rosto dos meninos chineses. Barthes, 2004, p. 96
\end{abstract}

Marc Roger é leitor público ${ }^{29}$ na La Voie des Livres, em Paris. Ele organiza estágios de formação de leitura em voz alta, de um dos quais eu pude participar, em setembro de 2007. Durante o estágio Marc trabalha com os alunos diferentes aspectos envolvidos na leitura em voz alta - como a escolha do repertório, a duração de cada leitura -, mas dá especial ênfase à apresentação corporal: o olhar e a voz.

Para Marc Roger, o leitor deve apresentar seu corpo pela voz e pelo olhar. Quaisquer outros movimentos ou interferências corporais podem distrair o ouvinte de seu foco central, que deve ser ouvir com as orelhas e ver o leitor lendo. Ele revela que olha para seu público para capturar a atenção, o olhar do outro. Os leitores públicos de sua companhia não têm um figurino especial ou adereços; podem ler tanto em pé quanto sentados, em função da duração da leitura e do conforto do leitor.

\footnotetext{
${ }^{29}$ Leitor Público - trata-se de uma figura atualmente cada vez mais popular, na França e em Portugal especialmente. Este leitor apresenta-se profissionalmente em diversos locais, lendo em voz alta contos, poesia, trechos de romance. Detalhes em www.lavoiedeslivres.com
} 
Valérie Delbore também é leitora pública. Ela coordena um grupo Les Mots Parleurs, também em Paris. Tive a oportunidade de entrevistá-la e de assistir a um ateliê de formação em leitura em voz alta em sua companhia. Durante a entrevista, Valérie diz: jamais olho para o público, jamais. Para esta leitora, olhar o outro desconcentraria sua leitura e possibilitaria a emergência de outros sentidos na relação com a platéia. Para ela, todo sentido deve ser carregado do texto ao outro, pela voz. Os leitores de sua companhia lêem em pé, em um palco, com uma roupa sóbria; utilizam uma estante de música para apoiar o texto a ser lido.

Embora utilizem técnicas diferentes, ambos os leitores buscam o olhar da audiência. Se Marc Roger lança seu olhar para fisgar o olhar do outro, Valérie Delbore se faz ser vista, oferece-se ao olhar do outro. Em ambas as companhias de leitura é evidente a força daquilo que chamaremos aqui de cena da leitura em voz alta.

No relato de Abreu (1997) sobre a leitura na literatura de Cordel, ler é encenar: um poeta oral cego lendo em voz alta o folheto. O que sabe o cantador dos versos é que a audiência precisa saber onde encontrar as letras para reproduzir a cena: no folheto, que deve ser adquirido. Se o cego não leu, mas memorizou o texto, pouco importa.

Élie Bajard (2007) traz alguns aspectos interessantes sobre a sessão de mediação de leitura que se aproxima bastante daquilo que aqui chamamos de cena de leitura em voz alta $^{30}$. Bajard observou o trabalho da instituição $A$ cor da letra ${ }^{31}$ na mediação de leitura com crianças. Para o autor, o dispositivo coloca em efervescência as duas matérias por meio das quais o texto escrito pode se apresentar - a gráfica e a sonora (2007, p. 46). Ao analisar as posturas e ações corporais dos mediadores, Bajard identifica quatro componentes semióticos na transmissão vocal do texto: a extração do texto pelos olhos, a emissão vocal, o olhar

\footnotetext{
${ }^{30}$ Mais adiante, discutiremos quais as diferenças entre as práticas de mediação e a leitura em voz alta.

${ }^{31}$ Centro de Estudos, Pesquisa e Assessoria em Leitura e Literatura Infantil, que funciona em São Paulo.
} 
endereçado ao ouvinte, a exposição do livro ao público. Estes componentes são os gestos de transmissão vocal.

O autor expõe uma técnica, um modo de ler que deve cumprir um protocolo de leitura, que neste caso é determinado pela Cor da Letra. A mediação de leitura é tomada a partir de um ponto de vista comunicacional (nas palavras do autor). Aqui talvez se encontre a maior diferença entre nossa proposta e a noção de mediação de leitura: não partimos de um ponto de vista comunicacional, mas consideramos a linguagem e a leitura em seus aspectos discursivo e subjetivante. Ao longo deste capítulo voltaremos às observações que marcam as especificidades que determinam nosso ponto de vista.

Identificamos, concordando com Bajard, que a leitura em voz alta implica gesto, corpo, língua, olhar e voz. Tomaremos gesto em um sentido um pouco diferente daquele que imprime Bajard, conforme veremos no desenvolvimento deste texto. Relevamos o foco na língua, na transmissão do texto, mas identificamos na voz não apenas um componente linguístico, da fala do escrito, mas um componente corporal e psíquico importante, como já foi visto nos capítulos anteriores.

\subsection{O olhar}

O que é um beijo, se eu posso ter o teu olhar?

Malemolência, Céu/ Alec Haiat

O olhar determina a cena de leitura em voz alta. Embora seja a voz aquilo que primeiramente isolamos como corporeidade significante, ao lermos em voz alta, a cena é instaurada pelo olhar. Não nos referimos apenas ao olhar que o leitor lança ao ouvinte, mas principalmente o olhar que aquele que escuta lança para o leitor. O leitor é visto e ouvido. Lembrando, Marc Roger usa seu olhar para fisgar o olhar do outro, da mesma forma que Valérie Delbore produz uma cena para ser vista. 
Diferentemente do modo de pensar de Bajard (2007), que considera que o olhar que o mediador lança para a criança é que determina a presencialidade na cena "ao vivo", consideramos que a cena é presencial porque é vista pelo outro, porque o leitor se dá a ver lendo, se mostra, se exibe, se insinua.

Mas há outro olhar que entra neste jogo de ler para o outro: o olhar que o leitor lança ao escrito. O que se instaura aí é um primeiro laço: o ouvinte vê o leitor olhando o escrito. Para avançarmos em nossa observação tomaremos as reflexões de Lacan a propósito da pulsão escópica, especialmente como apresentadas no Seminário XI.

Lacan identifica o olhar como objeto. Retomando as considerações de MerleauPonty sobre a noção de um "olhar preexistente", Lacan identifica um campo escópico, em que incide a pulsão, na esquize do olhar "eu olho/sou olhado". Antonio Quinet, a respeito da pulsão escópica, comenta que a pulsão indica que o sujeito é visto, que existe um olhar dirigido para o sujeito. (1977, p.155)

Dori Caymi e Paulo Cesar Pinheiro, em Desenredo, cantam uma metáfora deste olhar, que tudo olha:

O olhar que prende anda solto O olhar que solta anda preso Mas quando eu chego eu me enredo nas tranças do teu desejo

Para Brenman (2003), o olhar na atividade de leitura em voz alta não é importante; o que está em jogo é a escuta. A partir desta perspectiva, no momento da leitura em voz alta, não é necessário que as crianças olhem o professor (ou leitor) lendo. A atenção das histórias passa pelo ouvido e não pelos olhos, comenta o autor. Para ele, o olhar da criança está relacionado a um apelo narcísico do professor: possivelmente o professor quer ter a certeza de sua competência e se ilude acreditando que o olhar das crianças proporciona esta confirmação ( p. 121). 
De maneira distinta do que pensa Brenman, argumentamos que é o jogo olhar/ser olhado que inicializa o laço entre o leitor, o ouvinte e a escrita. Olhar que não remete a uma atenção, a um olhar atento, mas uma experiência estética, uma contemplação, que não necessariamente é sustentada durante toda a duração da leitura. Consideramos que a posição “ser olhado" remete mais a uma posição exibicionista do que narcísica: o que o leitor procura não é o olhar atento, mas o olhar invejoso.

Quem escuta a leitura não vê o escrito; vê o leitor enlaçado no escrito. Na cena, o leitor é visto em sua relação erótica com o escrito (lembrando Birman, 2006). E essa cena remete a uma relação desejante entre o leitor e o escrito. Quem vê alguém lendo, testemunha o leitor alienado, em completude com o texto.

Podemos pensar que o leitor se dá a ver na relação de desejo com aquilo que está lendo, e com aquele que o escuta e que o vê, testemunha da cena erótica. A partir de Lacan (1990), podemos localizar o voyeurismo do espectador, em resposta ao exibicionismo do leitor. Na relação exibicionista, ensina Lacan, o voyeur acredita que aquele que ele vê é completo, ele detém a causa do desejo, o objeto a. O objeto a é algo de que o sujeito, para se constituir, se separou como órgão. Isso vale como símbolo da falta, quer dizer, do falo, não como tal, mas como fazendo falta. (Lacan, 1988, p.101)

O olhar do leitor para o livro é a causa do desejo do espectador. O olhar daquele que o escuta revitaliza o gozo do leitor: sou invejado. O leitor sabe que a causa do desejo não está em um ponto localizável do escrito. Mesmo tendo lido várias vezes o mesmo texto há surpresas ou enganos que são sempre novos, a cada leitura.O mesmo livro, num mesmo dia, mas em um momento distinto, provoca outra leitura. A repetição é um retorno com diferença. (Fink, 1997) Por isso ler o mesmo nunca é ler igual.

O leitor, no entanto, se coloca como pleno, que é a condição para que, como suposto portador do traço unário, possa fisgar o olhar daquele a quem dirige o gesto 
exibicionista da leitura em voz alta, a partir de um movimento de alienação do sujeito ao outro, aqui suposto Outro. Segundo Lacan (1990, p.112)

Esta é a verdadeira inveja. Ela faz empalidecer o sujeito diante do quê??diante da imagem de completude que se refecha, e do fato de o $\underline{a}$ minúsculo, o a separado ao qual ele se suspende, poder ser para um outro a possessão com que este se satisfaz...

Temos, então, um primeiro esboço da cena de leitura:

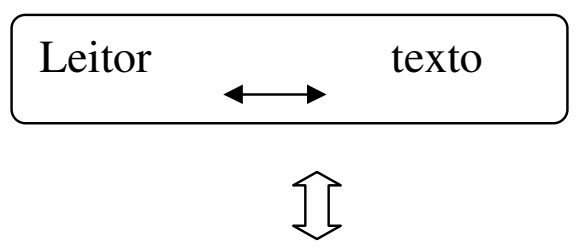

\section{Ouvinte/observador}

A partir daí, nossa cena de leitura envolve também uma linha, um anzol, que o leitor lança àquele que o vê lendo. Esse laço atirado pelo leitor ao ouvinte/observador é em um primeiro momento da ordem do visível, envolve a esquize do olhar (olhar/ser olhado). Mas o que sustentará este engate primeiro, em que aqueles que escutam a leitura aí se alienem, parte dos processos de identificação.

No Seminário sobre a Identificação, Lacan, logo na primeira lição, avisa: $o$ importante na identificação deve ser a relação do sujeito com o significante. E também na terceira lição vemos que o que está em jogo na identificação é a notação mínima, o traço mínimo que representa o sujeito. O que nos remete a uma escrita psíquica, feita de traços, de inscrições que na relação com o outro podem ser reconhecidas como próprias.

O ouvinte/observador acompanha a cena de leitura e é submetido a outro enlace, pela pulsão invocante. A cena de leitura em voz alta tem potencialidade para ser poderosa no sentido identificatório, pois mobiliza pulsionalidades muito próximas aos primeiros traços de enlace com o outro. No nível escópico, não estamos mais no nível do pedido, mas do desejo do desejo do Outro. É o mesmo no nível da pulsão invocadora, que é mais próxima da 
experiência do inconsciente (Lacan, 1988, p.102 . O que nos lança para um segundo elemento constitutivo da cena de leitura em voz alta.

\subsection{A voz}

A voz é o nó do sujeito.

Lew, 1989, p. 6

No capítulo anterior abordamos longamente as dimensões da pulsão invocante e da voz. Aqui vai nos interessar acessar a voz na cena da leitura em voz alta.

Como vimos, o olhar do leitor para o livro é a causa do desejo do ouvinteobservador, que foi convocado à cena a partir do apelo exibicionista do leitor. A cena erótica de leitura é acompanhada pela melodia vocal, dos timbres e modulações que entoa a leitura. Nestes traços, não linguísticos, mas potencialmente significantes, a cena vai construindo um tecido sonoro que sustenta o olhar e a escuta.

Ainda no Seminário IX, Lacan faz uma curiosa observação sobre sua cadela boxer: ela fala. Mas não o toma por outro. Nesta brincadeira, Lacan parece buscar afirmar a especificidade de uma fala na dimensão de uma escrita psíquica inconsciente e uma "fala" fora deste registro, que poderíamos pensar é uma fala tomada em sua função comunicacional. A distinção entre fala (como existe no pré-verbal) e a linguagem, consiste justamente nessa emergência da função significante.

Aquilo que a voz do leitor carrega é muito mais do que uma fala comunicativa, está mais próxima a uma escrita em voz alta. Uma escrita que, embora não possa ser lida, é objeto de desejo. O que se opera é uma identificação com o outro, por intermédio do desejo, na busca do "um".

O modo como a voz é produzida, a alternância entre a fluidez das vogais e a interdição das plosivas, o sopro das sibilantes, o prolongamento das nasais: nada disso tem significado, é todo o resto da operação de recalque e por isso mesmo continua a convocar. A 
leitura em voz alta areja o corpo sonoro tanto do leitor quanto do espectador, proporcionando possibilidades de identificação a partir da trama sonora. A cena se sustenta.

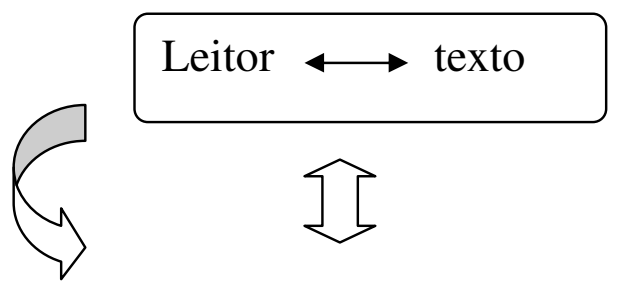

\section{Ouvinte/observador}

Na cena de leitura em voz alta o leitor não é apenas um laçador do olhar do outro. Ele também é capturado pelo texto. Há uma "latinha brilhante" que o olha no texto, para manter a metáfora de Lacan no Seminário XI; e é por isso que o leitor é também enganado, não pelo texto visível, por sua própria escrita em voz alta.

Mesmo lendo várias vezes o mesmo texto é sempre possível errar. Enquanto lemos, há algo "bolando as trocas”. Fato inadmissível para as teorias pedagógicas baseadas na extração do som no grafema, o erro é visto com naturalidade, por exemplo, entre os leitores públicos franceses, com os quais eu tive contato. Muito embora "indesejáveis", os equívocos fazem parte da relação com o texto, explica Marc Roger.

Minha sobrinha aos quatro anos de idade reuniu os adultos anunciando que ela iria ler. Abriu um de seus livros ilustrados e começou a "ler"; narrava fluentemente a história, sem gesticular. Em alguns momentos se detinha em uma parte de sua locução, silabando ou ralentando a leitura, como se estivesse experimentando alguma dificuldade em decifrar uma ou outra palavra. O que Julia parecia estar aprendendo é que ler é desafio para todos.

Ao lermos para o outro não é possível saber quais marcas, quais traços, quais significantes serão lidos pelo outro. Por isso a leitura em voz alta se constitui como um gesto de oferta. Oferece-se o corpo inscrito na relação de desejo com o texto. Enquanto flui a 
leitura há uma experiência de completude. Mas ela não dura muito. Ao terminar de ler um texto, a graça acabou, tudo voltou ao lugar depois que a banda passou, lembrando Chico Buarque.

A graça acaba porque o leitor não é mais leitor, ele agora é o mesmo, o outro, também - $a$. O término da leitura lança o escrito, o texto, à posição de objeto $a$. O que ficou da cena? Onde está a história? Lembrando Sartre: quem estava contando?

O que nos faz modificar um nosso diagrama, incluindo a triangulação: leitorouvinte-escrito:

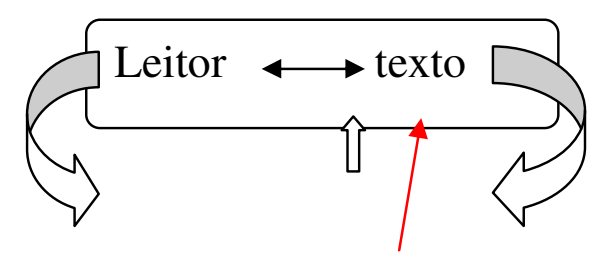

Ouvinte/observador

Esta observação é evidente em minha prática: após a leitura no presídio de Santana, as detentas não vieram falar comigo, e sim lançaram-se aos livros; nas leituras no Hospital, nos estágios que coordenei, muitas vezes os acompanhantes ou mesmo as crianças pediam para ficar um pouco mais com o livro. No consultório leio em voz alta para as crianças. Elas exigem que o livro vá para casa. E o livro vai.

Fernando tem seis anos e está em atendimento fonoaudiológico em função de dificuldades na fala, na sociabilização e no processo de apropriação da escrita. No início do atendimento, em setembro de 2008, Fernando não se interessava por ouvir leituras; queria apenas contar suas histórias, muitas vezes apresentado dificuldades na coesão e coerência em sua oralidade, além de distúrbios articulatórios (transtorno fonológico). 
Em fevereiro de 2009 a produção de escrita limitava-se a curvas e traços como o exemplo a seguir: sua lista de compras.

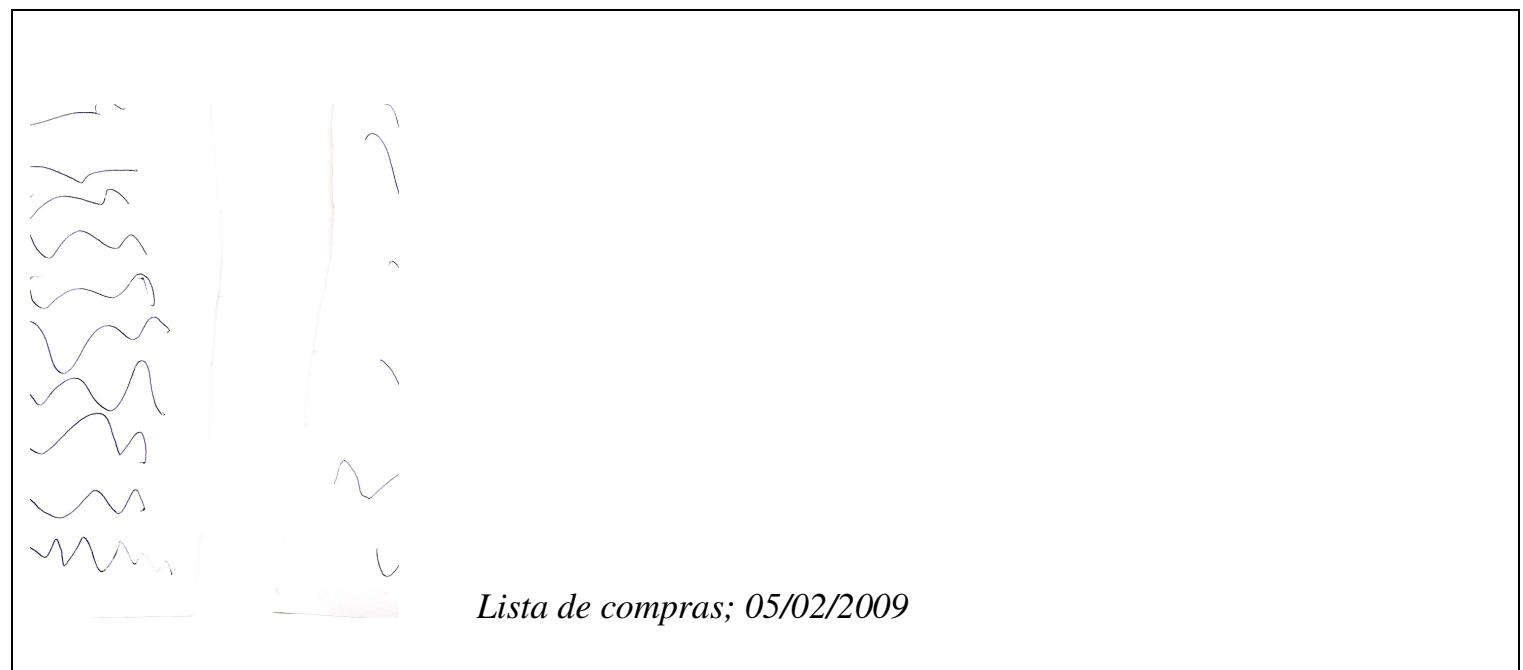

Figura 9 Lista de compras; 05/02/2009

Durante as sessões de atendimento, insisti na leitura, sempre buscando os livros de que eu mais gostava. Fernando foi se engatando até que, em uma sessão no mês de abril, pede uma leitura após a outra. Mais um! Mais um! E porque sempre sobrava uma vontade, passamos toda a sessão na atividade; foram seis livros. A partir de então, Fernando sempre leva os livros para casa.

No final do mês de abril, Fernando passa a brincar de livraria comigo. Expõe vários livros na mesa (escolhe os livros) e brincamos de compra e venda de livros; na sessão seguinte ele pede minha ajuda para organizar sua livraria; Fernando começa a escrever uma lista de livros: 


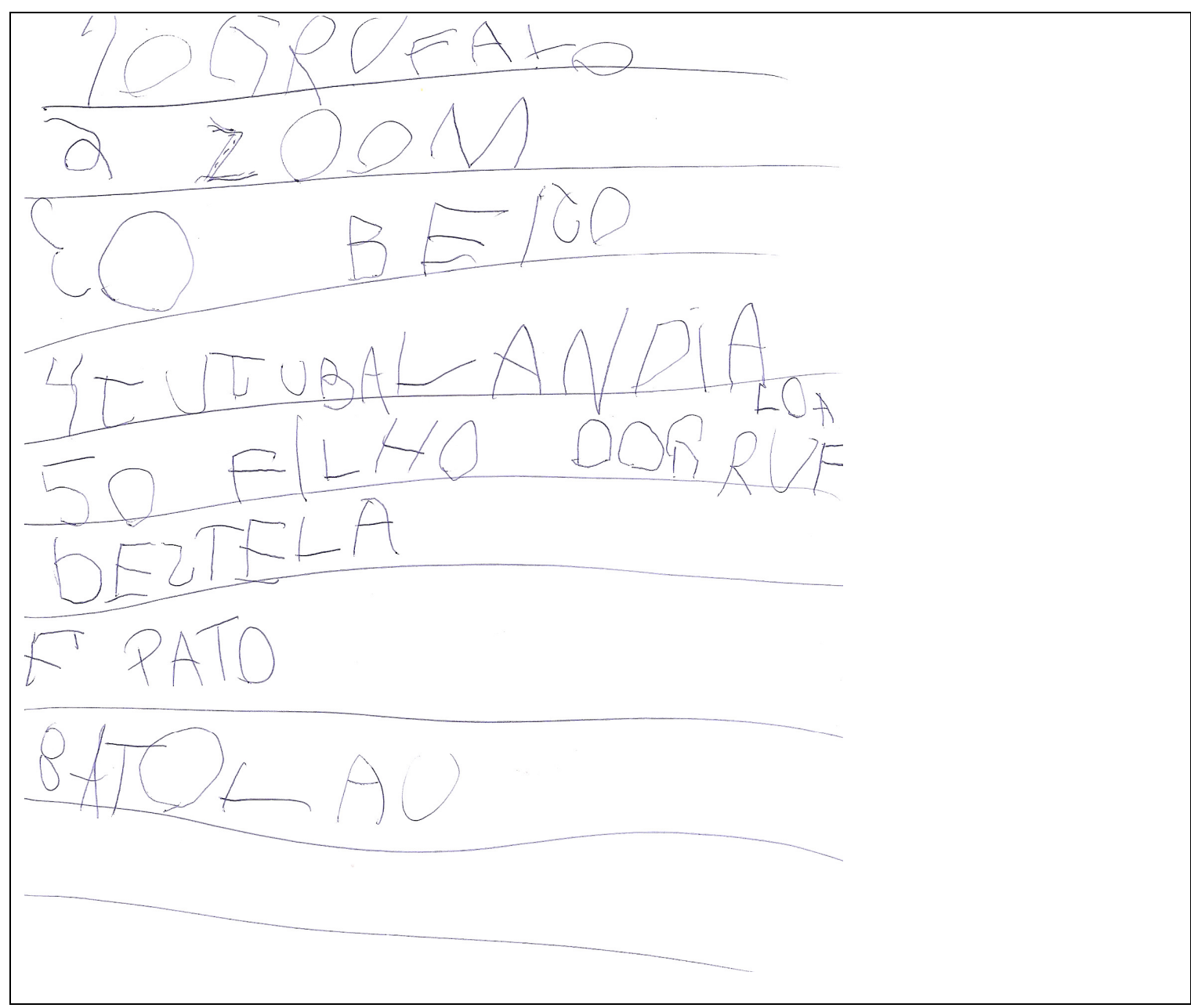

Figura 10 30/04/2009 Lista de livros da livraria - Observação: o item número 7 foi escrito por mim, a pedido da criança

É evidente que Fernando, na escola, estava também sendo motivado em sua entrada na escrita. Mas, por outro lado, não pode ser desprezível que seu engate ao material escrito esteja de alguma forma associado à experiência de ouvir as leituras.

Em mais uma cena clínica recente, em agosto de 2009, Fernando veio à sessão no dia em que nasceu a irmã caçula, acompanhado pela primeira vez pelo pai. Desenvolvemos as atividades normalmente; Fernando não parecia tocado ou afetado pelas mudanças na situação familiar. Quando faltavam cinco minutos para o término da sessão, eu o avisei da aproximação do final. Fernando foi imediatamente até a estante de livros e escolheu, por algum tempo, o livro que queria que eu lesse para ele. Por fim me entregou "O macaco 
danado", livro que ele já havia levado para casa. Logo na primeira frase Fernando se fez entender através do livro:

- Perdi minha mãe! $!^{32}$

Não pretendemos com estes recortes afirmar que toda leitura em voz alta tem sempre a mesma potencialidade. Mais adiante, na conclusão, discutiremos a questão da potencialidade versus eficiência da leitura em voz alta, no "fisgamento" da criança para a escrita. Por enquanto, vamos ao nosso próximo tema.

\subsection{A leitura compartilhada}

A cena da leitura em voz alta pode ser desenvolvida de diferentes maneiras, de modo que o ouvinte-observador possa ou não acompanhar a leitura vendo também as ilustrações do livro, por exemplo.

Neste caso, uma primeira atração já foi exercida: há um movimento em direção ao texto. Este é o tipo de leitura bastante comum com crianças que já se lançam de alguma forma em direção à escrita. A mediação de leitura pode ser considerada um tipo de leitura compartilhada.

Aquele que vê as imagens faz uma leitura imagética. A literatura infantil, na atualidade, oferece às crianças um livro que está longe de ser reduzido ao texto verbal. Podemos imaginar que o livro infantil seja um complexo semiótico que trança três tecidos: o tecido verbal, o tecido imagético e o tecido sonoro. O que colocamos aqui é que não se trata

\footnotetext{
${ }^{32}$ Primeira sentença do livro de Julia Donaldson; Axel Scheffler; Macaco danado , 1999.
} 
de uma questão visual versus verbal, já que as letras das palavras, ou seja, o verbal, são apreendidas pelo visual, na leitura. A escrita é visível, o verbal não se opõe ao visual ${ }^{33}$.

Alguns livros de literatura infantil que se encontram no mercado, atualmente, exploram exatamente a visibilidade das letras:

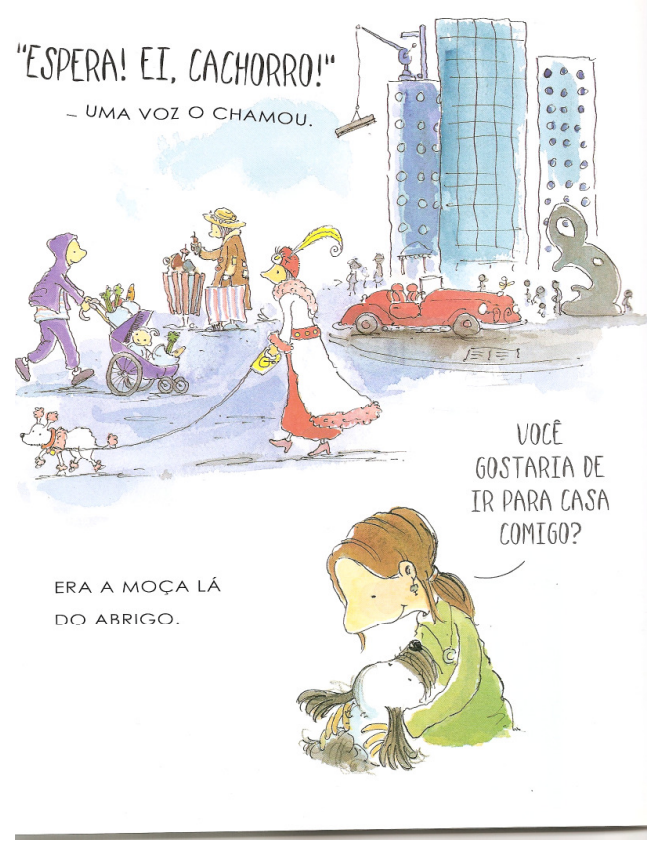

Figura 11 - Stephan Michael King-, Viralata, 2005

O texto, assim como a ilustração, forma a imagem, comenta Bajard (2007). O autor marca a diferença entre a literatura infanto-juvenil - em que a ilustração não desempenhava um papel semiótico - e a nova literatura infantil, em que existe um projeto gráfico; o livro apresenta pelo menos dois autores: o do escrito e o ilustrador.

Hoje as imagens impedem a fuga do olhar para longe da narrativa gráfica, comenta Bajard (2007). O que o autor nos apresenta é justamente o livro olhando o leitor, escopicamente, sendo quase impossível escapar deste apelo. E é o que garante também que

\footnotetext{
${ }^{33}$ Para um aprofundamento nas questões de escrita e imagem sugerimos as teses de Bosco (1999) e Burgarelli (2003).
} 
mesmo aquele que não é alfabetizado possa buscar o livro: há sempre uma possibilidade de leitura, de atribuição de sentidos.

$\mathrm{O}$ fato de a criança (ou aquele que compartilha a leitura com o leitor) poder ver/ler as imagens e letras que estão no livro não quer dizer que a voz de leitor cesse de produzir efeitos. É justamente nesta rede voz/olhar que a leitura provocará seus efeitos. A voz do leitor e o olhar para o visível do texto permitem ao espectador ouvir/ver o texto, viver a leitura: "ouviver".

$\mathrm{Na}$ leitura compartilhada, o olhar do espectador se divide entre o livro e o leitor. Mas permanece a cena da leitura em voz alta. Em um estudo anterior, foram observadas as reações de crianças de 06 meses a 12 anos no momento em que recebiam a leitura em voz alta, compartilhada, em ambiente hospitalar: dirigiam o olhar para o rosto do leitor e para a página do livro. (Barbosa, Pastorello et al., 2004)

Poderíamos talvez pensar que a leitura compartilhada já representa um engate importante no escrito e também na escrita. Aquele que escuta a voz do leitor continua testemunha voyeur da relação do leitor com o texto, mas dá um passo na direção de buscar entender de onde vêm as palavras, as histórias, o desejo da leitura. Podemos dizer que a criança, nesta cena, já está lendo, no sentido em que está envolvida em uma atividade de produzir sentidos a partir de material gráfico, visível; já há um texto que olha a criança, é o começo de um movimento de desejo em relação à leitura.

\subsection{O gesto de ler para o outro: vorleser}

Ler em voz alta, tomar uma chuveirada, amar e ficar um pouco mais juntos - esse tornou-se nosso ritual de encontros. Bernhard Schlink, O Leitor, 2009 , p. 50

O título original do romance $O$ Leitor, Der Vorleser, indica um gesto de endereçamento, no alemão, inscrito na palavra. De acordo com o dicionário alemão- 
português (1976) a palavra lesen - remete a ler; leser a leitor, vorleser - àquele que lê para uma outra pessoa. Ler em voz alta é um gesto endereçado ao outro.

Em francês, conforme se discute na Associação La Voie des Livres, existem dois termos que se referem à leitura em voz alta: à haute voix e à voix haute. Essa inversão dá conta de indicar a discriminação de uma intencionalidade: lire à voix haute implica o gesto de ler em voz alta para o outro, enquanto que lire à haute voix apenas indica a sonorização da leitura, opondo-se, assim, à leitura silenciosa.

Em $O$ Leitor, Bernhard Schlink constrói um romance que toca diferentes aspectos das relações entre escrita, poder e desejo. Aqui nos interessa focalizar a cena da leitura em voz alta, evidenciando o gesto, o laço com o outro.

Mas o que é um gesto? Em que se diferencia de um ato?

Rivière (1987) indica que o estudo da gestualidade, nas culturas ocidentais, é desenvolvido a partir da Segunda metade do século XX, acompanhando o crescimento do interesse pelas diferentes semióticas. $\mathrm{O}$ autor indica ainda que o gesto pode envolver "um algo mais a ser lido", nos atos de comunicação, e aponta Marx e Freud como autores que influenciam fortemente uma modificação do olhar que se lança ao gesto. O estudo do gesto permitiu a emergência de uma concepção de sujeito não idêntico a si e soberano, já que o gesto transmite um texto outro.

Tomamos aqui a dimensão do gesto como um movimento dirigido ao outro, (Rivière, 1987) e não nos preocuparemos em estudar a gestualidade na cena da leitura, como já fez Bajard (2007). Trata-se de sublinhar o endereçamento envolvido na cena de ler em voz alta.

Para Lacan, o gesto é um movimento dado a ver (1990, p.113). Enquanto no ato o que está em jogo são as relações do sujeito com o objeto, o gesto cria uma dimensão visível. 
O gesto de ler para o outro cria a cena, evidencia a dimensão escópica e invocante.Ao mesmo tempo, há no gesto de ler em voz alta um abraço sonoro, invocante.

Viola (2006) teoriza o gesto vocal, que seria uma composição dinâmica de elementos fisiológicos e linguísticos que integra a voz no universo da linguagem. Tomar a voz como gesto é entender que a voz é dinâmica, flexível e adaptável. (2006, p. 206)

O gesto vocal envolve o corpo em funcionamento, a serviço de um laço com o outro. Para Zumthor (2007), a voz é um corpo que vai em direção ao outro e retorna. Ora, esse caminho, de ir ao outro e retornar, enlaça o outro, circula o outro, pulsionalmente. Aqui conta menos a intencionalidade do gesto do que a direcionalidade, a qual, como vimos, criará a cena de leitura fazendo circular o desejo. Kristeva (apud Rivière, 1987) fala em gesto como aquilo que instaura relações, antes e depois da voz e da grafia.

$\mathrm{O}$ fato que aqui se procura valorizar é o que o movimento parte daquele que se propõe a ler. A forma como se lê e a maneira de se encontrar com o texto irão determinar o laço inicial no gesto leitor. Assim, o que estamos procurando teorizar neste trabalho não é da ordem do generalizável: toda leitura em voz alta é invocante e transformadora. O que procuramos trazer é a potencialidade da cena de leitura em voz alta: um gesto exibicionista, uma provocação, um pedido de encontro:

Não me preocupei com o fato de que Hanna, agora, depois de ter aprendido a ler, pudesse não precisar mais de minhas fitas. Ela podia ler também sozinha. A leitura em voz alta era minha maneira de falar para ela, com ela. (Schlink, 2009, p. 208)

O que determina a potencialidade da leitura em voz alta não é sistematizável, mas está relacionado ao modo como o leitor se posiciona na relação dialética do sujeito com o desejo e com o outro.

Alguns meses depois de meu ingresso na escola, aconteceu algo solene e excitante que determinou toda minha vida futura. Meu pai me trouxe um livro. (...) Na capa havia uma ilustração colorida, creio que de Aladim com a lâmpada maravilhosa. Falou-me de forma animadora e séria de como 
era lindo ler. Leu-me uma das histórias; tão bela como esta seriam também as outras histórias do livro. Agora eu deveria tentar lê-las, e à noite eu lhe contaria o que havia lido. Quando eu acabasse de ler este livro, ele me traria outro. Não precisou dizê-lo duas vezes, e, embora na escola começasse a aprender a ler, logo me atirei sobre o maravilhoso livro, $e$ todas as noites tinha algo para contar. Ele cumpriu sua promessa, sempre havia um novo livro e não tive que interromper minha leitura um dia sequer. (Canetti, 2005, p. 50)

Em A língua absolvida, Elias Canetti (2005) recupera as lembranças de sua infância, conferindo à leitura um lugar especial: o gesto de oferta de livros pelo pai, morto precocemente; as sessões de leitura em voz alta realizadas por sua mãe; o ciúme, a inveja e o simbolismo dos textos que lhe eram proibidos, dados à mãe por um admirador.

Minha mãe ainda estava se recuperando, e por esse motivo nossas sessões de leitura se espaçaram. Ela já não representava para mim e só permitia que eu lesse em voz alta. (...) Mas com freqüência, ela ficava pensativa, como se eu não estivesse presente. "Você não me presta atenção", dizia eu, e ela estremecia e se sentia flagrada. Eu sabia que ela pensava em outra leitura, da qual não me falava.

Ela lia os livros que Herr Professor lhe dava e me advertia com severidade que não eram para mim. $(2005$, p. 141, 142)

Também Markus Zusak em A menina que roubava livros, oferece diferentes aspectos que são colocados em jogo na cena de leitura em voz alta. Neste trecho selecionado, a protagonista, Liesel, lê em voz alta um livro ( $O$ assobiador $)$, em uma situação particular durante um bombardeio, em um porão na Alemanha nazista -, acompanhada de familiares e vizinhos que ali se protegiam:

A menina não se atreveu a levantar os olhos, mas sentiu os olhares assustados prenderem-se a ela, enquanto ia puxando as palavras $e$ exalando-as. Uma voz tocava as notas dentro dela. Este é o seu acordeão, dizia.

O som da página virada cortou-os ao meio.

Liesel continuou a ler.

Durante pelo menos vinte minutos, foi entregando a história, As crianças menores se acalmaram com sua voz, enquanto todos os outros tinham visões do assobiador fugindo da cena do crime. Não Liesel. A menina que roubava livros via apenas a mecânica das palavras - seus corpos presos ao papel, achatados para the permitir caminhar sobre eles. Além disso, em algum lugar, nos hiatos entre uma frase e a maiúscula seguinte, também havia Max. Liesel lembrou-se de ter lido para ele quando o rapaz estivera doente. Será que ele está no porão? Pensou com seus botões. Ou estará roubando um vislumbre do céu? (Zusak., p. 332, 333) 
Os testemunhos biográficos de Canetti e Sartre, as criações literárias de Bernard Schlink e de Markus Zusak evidenciam a especificidade da leitura em voz alta como enlaçadoras e subjetivantes, já que a voz faz ressoar a gramática pessoal de cada um, diz Lew, 1988. Poderíamos acrescentar que a escuta da voz toma a mesma dimensão.

Mas há no gesto de ler para o outro algo que é determinante e que sustenta seu valor singular na apropriação da linguagem escrita pela criança: a transmissão da cultura.

\subsection{Ler para o outro: testemunho de assujeitamento à cultura}

Como vimos, a cena da leitura em voz alta cria uma triangulação que envolve texto, leitor e espectador. Vimos que esta cena envolve elementos escópicos e invocantes que podem conduzir à emergência do sujeito. Mas, em que medida podemos pensar esta cena e a apropriação da escrita pela criança?

Podemos identificar, na cena de leitura em voz alta, momentos particulares, como expostos neste capítulo. Um dos pontos fundamentais que evidencia a cena da leitura em voz alta é a alienação do ouvinte/observador ao leitor. Na cena de leitura em voz alta, o espectador é levado a optar por um caminho: ou entra ou não entra na leitura pelo corpo do outro. Aí vemos uma metáfora do vel da alienação: o espectador julga que o leitor está em completude. Deixando-se laçar pelo leitor e embarcando na leitura, o espectador espera: espera ser preenchido. Neste primeiro passo, o sujeito sai de cena para dar lugar ao Outro que está na leitura, no vorleser.

O que o vel da alienação porém pode conduzir a outro momento até então velado: o leitor é um semelhante, a cena acaba; as palavras mágicas voltam às páginas do livro, a cantiga da leitura não embala mais. Para onde vai a mágica da cena? 
Repetir a leitura não será a mesma coisa. As crianças pedem e repetem: mais um! A repetição dos pequeninos em relação às histórias pode permitir que eles encontrem ou reencontrem os significantes em posições que lhes permitam articular aos poucos uma cadeia, sustenta Tavares (1998).

Também lembrando Lacan no seminário XI: a graça do jogo fort-da, descrito por Freud, pode não estar tanto no início da simbolização do objeto faltoso e de sua presença, mas na necessidade de viver a realidade da falta. Todas as histórias, todas as leituras acabam.

Podemos identificar ainda outro véu lançado pelo vel da alienação: aquele que encobre o assujeitamento do leitor à imperatividade das letras, à intransigência da língua. Além disso, eu não reconhecia sua linguagem. Onde é que arranjava aquela segurança? Ao cabo de um instante, compreendi: era o livro que falava (... ), observa o pequeno Sartre ao ver sua mãe lendo.

O que o leitor pode transmitir nas cenas de leitura em voz alta se assemelha a uma sonata maternante, indicada por Didier-Weil (1999): a corporeidade das vogais, os cortes e silenciamentos das consoantes. Aos poucos vai sendo evidenciado para o espectador, nas cenas de leitura que se repetem, que há um Outro no outro que lê. Comenta Fink (1998): o Outro materno precisa mostrar sua imcompletude, falibilidade ou deficiência para que se concretize a separação. Mas é importante observar: é o posicionamento enunciativo e subjetivo daquele que lê que permite este desvelamento. É o leitor que é fiel ao texto, que eventualmente se equivoca, com lapsos; este leitor, que mostra sua falta, é o leitor que convoca a relação sujeito-cultura. Nas palavras de Sartre: a gente fala em sua própria língua e escreve em língua estrangeira. Daí concluo que somos todos semelhantes em nosso ofício: todos forçados, todos tatuados (1967, p. 104).

Descobrir buracos no outro, perceber a falibilidade do leitor supostamente competente, pode permitir àquele que está em processo de formação como leitor procurar seu 
próprio caminho, separar-se. Trago aqui mais um recorte oferecido pelo atendimento de Priscila, a mesma garota que nos mostrou a polissemia textual, dizendo que quem estuda direito é um bom aluno.

Priscila comenta em uma sessão que, ao ler um livro em casa, achou um erro. A menina estava um pouco desconcertada com a situação. Pedi que ela me mostrasse o erro e, de fato um erro de concordância aparece na página 17 do "Marcelo, marmelo, martelo", clássico de Ruth Rocha (5ª edição, 59ª impressão, 1999).

Comentei que ninguém está livre de errar, nem os autores dos livros. Então a menina me questionou se a autora sabia que tinha errado. "não sei, vamos avisá-la?", propus.

Foi então que Priscila se espantou e ao mesmo tempo se lançou na escrita. Elaboramos uma carta para a autora e envia mos pelo correio.

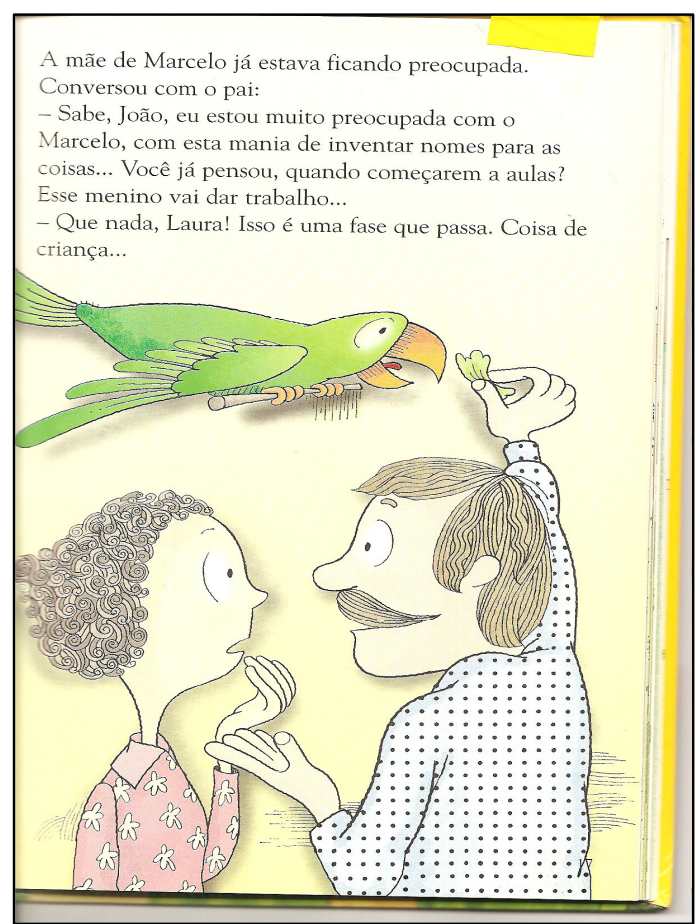

Figura12 - Ruth Rocha, Marcelo, marmelo, martelo. 1999, p. 17 


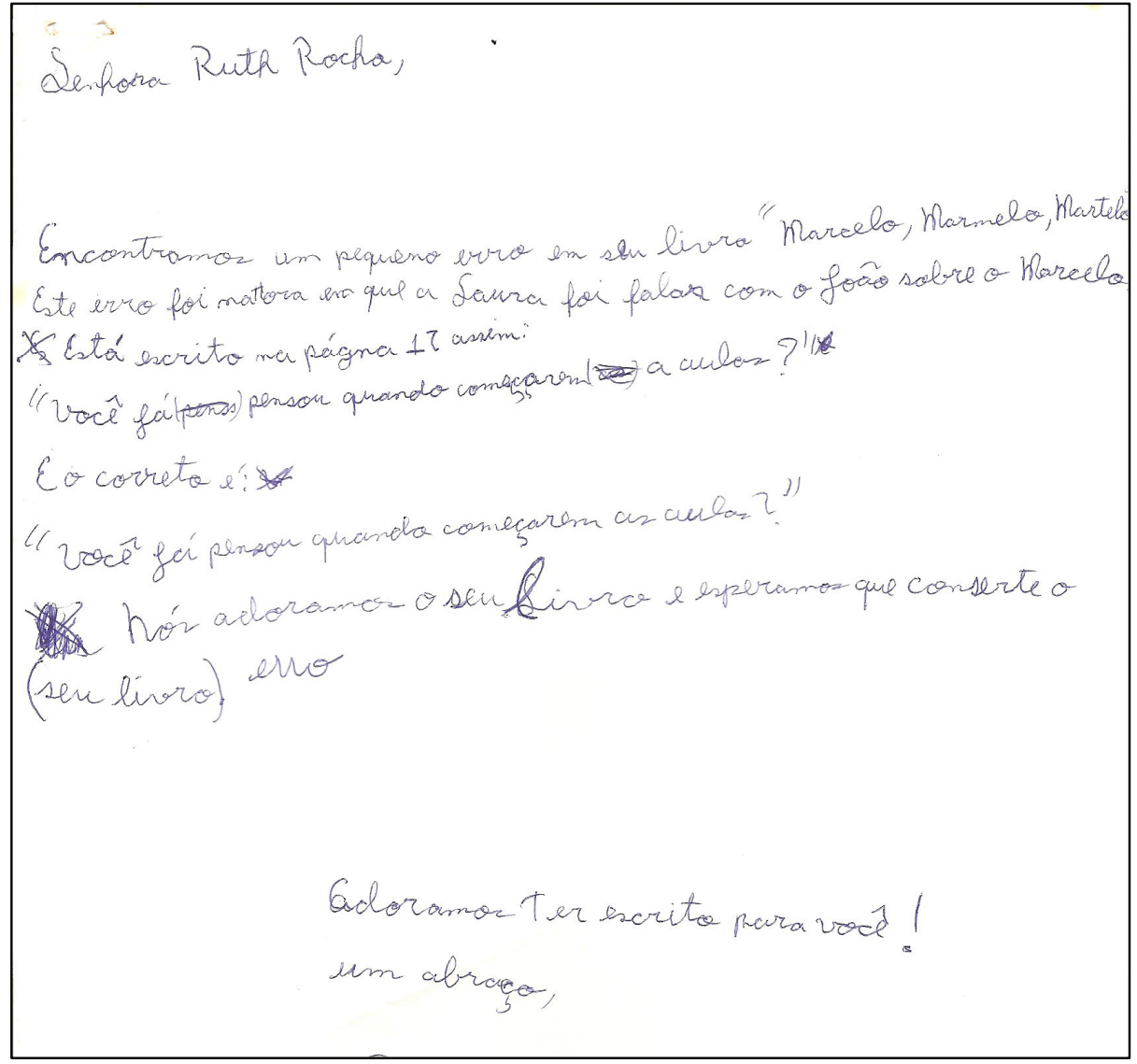

Figura 13 - carta para Ruth Rocha

Senhora Ruth Rocha,

Encontramos um pequeno erro em seu livro "Marcelo, marmelo, martelo". Este foi na hora em que a Laura foi falar com o João sobre o Marcelo.

Está escrito na página 17 assim:

"Você já pensou quando começarem a aulas?"

E o correto é:

"Você já pensou quando começarem as aulas?"

Nós adoramos seu livro e esperamos que conserte seu erro.

Adoramos ter escrito para você,

Um abraço,

Priscila e Lucila

Algumas semanas mais tarde, recebemos uma resposta da editora: 
EDITORA MODERNA

Era uma vez alguém que leu um livro,releu,gostou e curtiu tanto que resolveu escrever para o dlono da história.0 pessoal da editora recebeu a sua cartinha e ficou tão feliz que resolveu encaminhá-la rapidinho para o autor:

Essa historia tem a ver com você DSim,é claro,e sailha também que ela sempre terá um final feliz,porque a melhor coisa que pode acontecer pra nós,que fazemos o liuro,e para o autor; que escreve, é saher o que você acha das mossas histórias.

É muito importante que você continue lendo,lendo tudo o que puder;todos os autores de que gostar; sobre todos os temas que despertarem seu interesse. Só assim você poderá descohrir os muitos caminhos que os liuros podem ahrir na sua viida, e escolher o que melhor sintoniza com seus sentimentos.

Ria,chore,sinta,leia,leia,leia ...os livros podem fazer de você uma pessoa muîto mais criativa . Acredite nisso.

E boas aventuras !!!!

Um aluraço,

Editora Moderna Ltda.

Figura 14- Resposta da editora

Embora esta carta pareça ser um texto padronizado, enviado às crianças que escrevem para os autores, Priscila tomou a si como destinatária. Emocionada, saiu da sala de atendimento, buscando mostrar a qualquer um a carta que recebera. Mais algumas semanas e recebemos outra carta, que dizia: Priscila e Lucila: vou olhar sim no livro e obrigada por me avisar. Ruth Rocha. ( figura 13):

A partir deste episódio as queixas de Priscila foram cessando. A menina passou um período lendo livros em busca dos "erros". Este trabalho fez com que sua leitura se tornasse mais lenta, mas a atenção aos detalhes do escrito mobilizou uma apropriação ortográfica. Após algum tempo, Priscila passou a se encantar com os movimentos do texto, com a história e abandonou sua função de "revisora". Antes disso, achou um erro no livro "O 
príncipe sem sonhos" (Brinquebook), mas se contentou com minha promessa de avisar a editora por telefone.

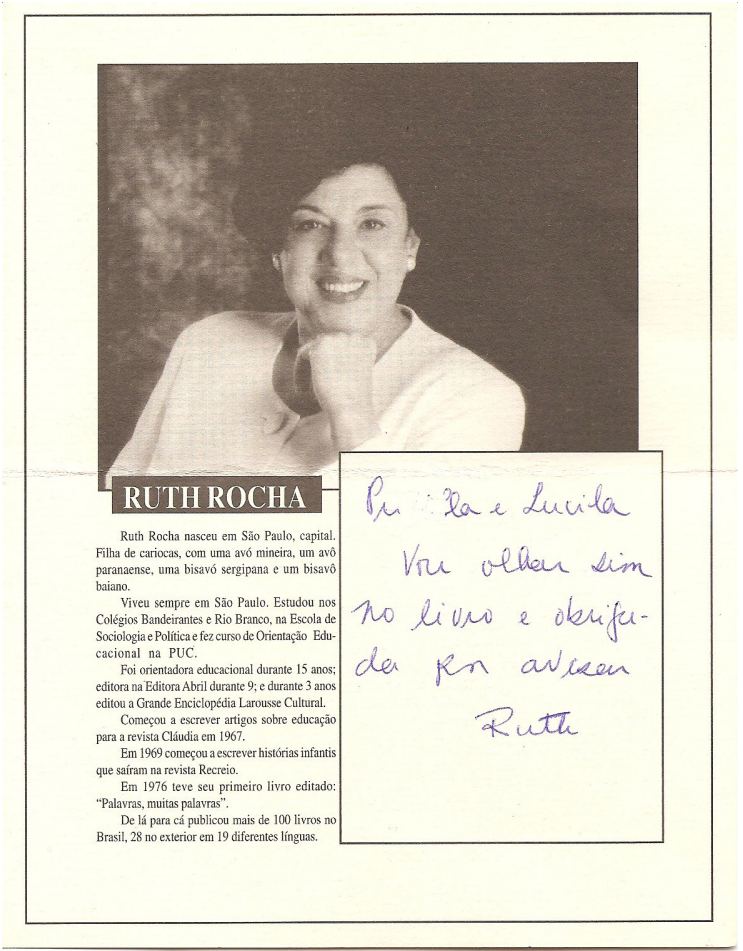

Figura 15 - Resposta de Ruth Rocha

A descoberta de Priscila de que todos erram, de início desconcertante, pode ter relação com seu movimento em direção à escrita. A possibilidade de poder "corrigir" a autora e ser por ela reconhecida ilustra o processo de separação: há um Outro do outro. Ler e escrever se apresentam assim como processos passíveis de equívocos.

O Outro implicado na separação não é o Outro implicado na alienação, diz Colete Soler (1997, p. 63). O aspecto faltoso é que está implicado no Outro da separação. E ainda mais uma vez: assim como no movimento da alienação é o leitor que dá o primeiro 
laço, também é no processo de separação que o leitor deve deixar aparecer sua incompletude: não em palavras, mas em gestos, em atos, na leitura.

Não se trata de errar de propósito: errar intencionalmente está mais próximo de um jogo, que o interlocutor percebe, pois neste erro fabricado não há a presença de um corpo flagrado pelo engano. Trata-se de permitir a emergência subjetiva, o que não se dá por decreto ou intenções, mas a partir de um posicionamento a partir do qual o erro ou tropeço não seja aniquilador. Um posicionamento tal que considere a incompletude como condição de existência e não como ameaça à existência.

Uma das idéias essenciais contidas na separação é de uma justaposição, superposição ou coincidência de duas faltas. (Fink, 1998, p. 76) A cena da leitura em voz alta, por suas particularidades - evidenciamento do corpo e presencialidade a partir do olhar pode ser especialmente subjetivante, no sentido de oferecer significantes mobilizadores dos processos de alienação e separação.

Ler em voz alta um texto pela primeira vez, por exemplo, é uma tarefa em que muitas vezes qualquer leitor competente comete enganos.

Rodrigo, aquele rapaz que costuma ler em voz alta para uma platéia feita de lápis, canetas e borrachas, recentemente trouxe livros de uma coleção que está lendo (Zac Power $\left.{ }^{34}\right)$ para funcionarem como platéia. A cada sessão inventamos formas novas de realizar a leitura compartilhada.

Começamos alternando a leitura em voz alta: cada um de nós lia uma página. Então passamos a alternar o leitor a cada parágrafo; depois a cada ponto final, a cada sinal de pontuação: impossível não se equivocar em algum momento. O comentário de Rodrigo "você errou", soava como um troféu: olhos atentos ao escrito, ouvidos afiados para pegar a fonoaudióloga no pulo.

\footnotetext{
${ }^{34}$ Hi Larry, 2008.
} 
Evidentemente essas atividades comprometem em parte a atribuição de sentido ao texto, por valorizarem o corpo do escrito, os sinais no papel. Mas nessa brincadeira há também uma dessacralização do escrito e da leitura, uma abertura de possibilidades lúdicas e de fazer dançar corpo e voz. Um ritual de apropriação que lança desafios: quem escuta está fiscalizando também a aventura do leitor, já que nesta leitura compartilhada ambos têm acesso ao escrito. Algumas vezes relemos os trechos envolvidos nas brincadeiras, para garantir a emergência do sentido.

A leitura limpa, sem erros, com sua emoção contida nas intenções calculadas como as leituras avaliativas da pedagogia tradicional de que fala Kleiman (1993) - , transmite a noção de uma perfeição leitora, sem emergência de sujeito, portanto difícil, impossível, enfadonha e cansativa.

A leitura em voz alta é provocante: invoca o outro e evoca significantes. Em tal prática emergem, de forma evidente, os lugares da linguagem, conforme Foucault (2009): boca, ouvido, olho. Órgãos onde habita a linguagem, que se revezam em excitação, conforme a dimensão da linguagem que é posta em cena: o sentido, a sonoridade, o código. Ao ler em voz alta, o olho abre para as letras e comanda a cadência da leitura a partir do sentido formado pela relação código-letra-palavra; mas é também o ouvido aberto que indicará à boca os deslizamentos, as ênfases, a pauta sonora que se percebem nas rimas, aliterações, repetições.

O leitor se vê às voltas com a língua e a emergência subjetiva. Ao mesmo tempo ainda há fruição: o leitor é obediente às palavras da língua, mas sua leitura em voz alta imprime outros textos, os não-ditos, a dança da língua ao som além da língua. Nas entrelinhas, nas respirações, nos deslizamentos vocais, nos deslizes, o leitor tece a sonoridade revelando sua gramática singular. Esta trama sonoro-coporal invade os vazios de sentido que 
todo texto comporta, criando marcas, evidenciando traços, indicando o que é necessário no assujeitamento: não a exclusão do sujeito, ao contrário, sua presença na presença da lei.

Mais ainda: o leitor não diz o texto, ele o lê. O leitor faz viver o autor do texto. Lembrando Whitman, ao se remeter a seu leitor: Não tenhas muita certeza de que não estou contigo. Na leitura de textos literários, em especial textos polissêmicos, polilógicos, poéticos, o leitor faz aparecer a criação literária naquilo que ela pode comportar de transgressora, inovadora: ao invés de contornar as dificuldades da língua, o que está em jogo é sacudir as palavras, arejar os sentidos. O leitor se aliena ao Outro do texto, se oferecendo como suporte de seu discurso, podendo suportar a castração depositando no Outro seu gozo interditado.

Voltando à cena de leitura, podemos complexificar a posição invejosa do espectador: não apenas a inveja em relação ao leitor naquilo que ele se deixa ver fazendo com o texto, mas uma inveja não localizável: do leitor, do autor, da leitura, da dança do corpo ao som dos nonsenses, das relações inusitadas, dos murmúrios d'água, da linguagem.

Este algo não localizável - ora leitor encarnado, ora escrita, ora livro - aliado à percepção de um semelhante - leitor-faltoso, portanto desejante -, potencializado pulsionalmente pela voz e pelo olhar nas cenas de leitura, pode permitir circular o desejo do espectador também dispersivo: de ler, de possuir o texto, de ser o leitor. O espectador pode separar-se da cena de leitura, do leitor e caminhar em busca de sua singularidade leitora:

Tive então ciúmes de minha mãe e resolvi tomar-lhe o papel. Apossei-me de um livro intitulado "Tribulações de um chinês na China" e o transportei para um quarto de despejo; aí empoleirado sobre uma cama de armar, fiz de conta que estava lendo: seguia com os olhos as linhas negras, sem saltar uma única e me contava uma história em voz alta, tomando o cuidado de pronunciar todas as sílabas. (...)

Fiquei louco de alegria; eram minhas aquelas vozes secas em seus pequenos herbários, aquelas vozes que meu avô reanimava com o olhar, que ele ouvia e eu não! Eu iria escutá-las, encher-me-ia de discursos cerimoniosos e saberia tudo. (J.P. Sartre, As palavras, 196, p. 32) 
Este depoimento de Sartre faz aparecer o Outro, nos outros: na figura da mãe e também do avô. A partir das experiências de leitura de sua infância, que o autor vai reconstruindo em As Palavras, é possível notar a dimensão das cenas: olhar, ouvir, se deleitar, estranhar outro, esperar pelo texto, pela repetição, sentir a falta de não ler e enfim invejar, imitar, fazer-se outro, atravessar o visível e finalmente ler.

Uma última observação, antes de partirmos para nossas conclusões: no desenvolvimento deste capítulo, utilizamos as noções de alienação e separação tais como introduzidas nos textos de Jacques Lacan. Tratamos de evidenciar como tais operações subjetivantes podem ser identificadas nas cenas de leitura. Contudo, é importante que fique claro que tais processos não obedecem a uma linearidade temporal, não acontecem obrigatoriamente em cada cena de leitura em voz alta.

Fink assinala que alienação não é um estado permanente; ao contrário, é um processo, uma operação que ocorre em determinados momentos (1998, p. 73). É evidente que não é apenas uma cena de leitura em voz alta que provoca efeitos no ouvinte-observadorespectador; mas também não significa que uma cena, digamos "inaugural" não possa acontecer.

Como a sonata materna, a leitura em voz alta não é evento único, muito embora possa ser singular. A criança em seu processo de apropriação da linguagem oral está envolta em movimentos linguageiros de diferentes naturezas. Mas é o posicionamento subjetivo do(s) outro(s) que a cerca(m) que vai permitir que a criança fale.

Para que a criança conheça a escrita visível é importante que ela seja exposta tanto a uma diversidade de gêneros discursivos quanto é preciso que seja letrada pelo outro. Mas para que a criança se lance com desejo na escrita é preciso que ela seja letrada por outra escrita que se produz nos processos inter e intrassubjetivos; é preciso que ela seja convocada a se deixar tatuar pelo ofício de escrever em diferentes suportes: da voz ao visível. 


\title{
Capítulo 5: Considerações finais
}

\author{
Se é real a luz branca \\ desta lâmpada, \\ real a mão que escreve, \\ são reais os olhos que olham o escrito? \\ Duma palavra à outra \\ o que digo desvanece-se. \\ Sei que estou vivo entre dois parênteses. \\ Octavio Paz, Certeza, 1984
}

Ao longo deste trabalho procuramos teorizar a partir dos parênteses oferecidos por testemunhos singulares da clínica e da literatura literária. Foi desses encontros - com os dizeres de crianças supostamente frágeis na apropriação da linguagem, e com biografias e a criação literária -, que pude extrair alguma certeza sobre o que aqui está dito. A certeza a que se pode chegar: ter reunido argumentos que possibilitam lançar um novo olhar para a discussão sobre a apropriação da escrita e da leitura em voz alta.

A finalização de um percurso é um desafio na medida em que implica o reconhecimento das limitações de nossa própria pesquisa, de nossa escrita, da possibilidade de esgotar o tema. Enquanto ainda escrevemos, sabemos de nossa falta, sabemos que o texto não está completo. Mas, e quando acabar a escrita?

Paul Zumthor (2007) discute a ilusão que a interdisciplinaridade carrega: uma promessa de completude. Em parte, foi essa a ilusão que provocou e motivou nossas leituras, olhares, escutas, escrita. Mas a questão se impõe: neste trabalho, marcadamente interdisciplinar, onde está a completude, a certeza imaginada? Finalizar, concluir é estar face a face com a impossível certeza da teoria, mas também é poder vê-la viva a partir daquilo que é oferecido pelo outro: escritores e crianças, meus co-autores neste percurso.

No início deste projeto, saímos em busca do corpo sonoro e das especificidades da leitura em voz alta, considerando essencialmente a sonoridade e a pulsionalidade vocal. No 
momento da Qualificação, vimos que podíamos ir além: o olhar do outro sustenta nossos passos. A partir daí, pudemos ver a cena de leitura desfilando há tempos sob nossos olhos: o rei está nu!

É desta certeza que tratamos aqui: é possível olhar sempre, de novo, e ver o novo. Nosso questionamento central: teria a leitura em voz alta especificidades que a tornam capaz de interferir positivamente na apropriação da escrita pela criança?.

Partimos da hipótese de que a resposta a esta questão é afirmativa, e aqui reunimos argumentos para sustentar nossa resposta. A leitura em voz alta pode interferir positivamente na apropriação da escrita em função de suas especificidades, a saber: seu caráter pulsional - escópico e invocante - , seu caráter performático e presencial e sua potência de transmissão da cultura, a partir de um posicionamento subjetivo frente à língua, ao desejo e ao outro.

Tais características colocam a leitura em voz alta como um evento que pode promover a emergência de processos de subjetivação: a alienação e a separação. Lembrando Jaqueline, a garota que passou de espectadora para leitora, uma das cenas que provocaram este trabalho: não sabemos se ela escreve bem, se lê com gosto, atualmente. O que sabemos é que as cenas de leitura a mobilizaram em direção ao outro-leitor: Jaqueline foi atraída, como diz Bajard.

Podemos pensar as cenas de leitura em voz alta como rituais de apropriação: assim como Jaqueline, as crianças que tropeçam na linguagem escrita - algumas diagnosticadas como disléxicas - em minha experiência clínica podem se movimentar na escrita: lendo em voz alta, para uma platéia feita de lápis, borracha, canetas coloridas. Os sinais gráficos começam a fazer mais sentido ao som da melodia da voz. Ler começa a fazer sentido, quando as letras podem ser sentidas, incorporadas, quando se pode conviver com os 
buracos, com os não ditos, preenchidos pelo nonsense da voz. Ler em voz alta é aparecer entre parênteses.

Tal aparição remete à emergência do sujeito. Com a evidência dos lapsus calami introduzida por Freud, percebemos que ler sempre nos acena com um "não confunda"; é sempre possível confundir boladas com baladas, há sempre algo bolando as trocas. Se a leitura é naturalmente uma experiência de alteridade, um lugar de encontro entre o autor e leitor - como destacam Whitman (Borges, 1996), Iser (1996), Chartier (2001) e Jouve (2002) - a leitura em voz alta potencializa não apenas o encontro com o autor, mas o encontro com o outro que temos por dentro - como disse Veríssimo - e com o outro para quem se lê, que instaura o vorleser, um leitor a voix haute.

A natureza desta potência está ligada à evidência do corpo na leitura, à circulação pulsional escópica e invocante que aliena o ouvinte/observador na cena de leitura, na promessa de completude. A dúvida de Brenman: talvez o desejo pela letra contida no livro venha da voz do leitor. Consideramos que agora podemos responder: sim, certamente, mas também o olhar tem a ver com esse desejo. A circulação do desejo na leitura advém de um ato testemunhal, invejoso, voyeur, mas que é instaurado pelo leitor. Foi assim que vimos com as detentas do presídio nas oficinas "Brincar de ler", e com Rafael, alienando-se à leitura em voz alta e buscando o escrito quando a voz cessa; e também com a instalação de um Vorleser de Rodrigo e sua platéia, que numa fase posterior se transmuta de lápis e borrachas em uma fileira de livros.

Bajard comenta: a criança é atraída pelo mundo literário pela voz do mediador. Como ela é atraída?, questionamos então. Ela é atraída pelo leitor. É ele quem oferta sua relação com o escrito. É ele que se dá a ver e ouvir, que se exibe todo poderoso, deslizando sobre as letras musicalmente, fazendo dançar a língua ao som de sua corporeidade. É o leitor que se faz desejar. Neste sentido a presencialidade da cena de leitura é determinante 
para que estes movimentos aconteçam. É preciso que estejam leitor/escrito e espectador respirando o mesmo ar; é preciso que a energia possa contaminar leitor e espectador.

Que energia é essa? Como teorizar essa energia? Aqui podemos afirmar que esta energia é pulsional; é a energia que cria as bordas, que permite circular o vazio e delimitar algum espaço a ele. Na presença do outro lendo em voz alta, há uma contaminação deste algo não dizível, não higienizado, indecente, promíscuo, que não pode ser posto em palavras: o corpo, as sensações de se ser deixado levar por algo sem explicação.

A voz é um corpo que se lança ao outro e retorna, é de Zumthor (2007) esta bela metáfora para a pulsão invocante. Na cena de leitura a voz do leitor contorna o espectador, aquele cuja presença e olhar confirmam, mesmo que por instantes, a experiência de ser um.

Mas essa cena, diríamos ideal, pulsional, cativante, estaria essa cena sempre presente na leitura em voz alta?

Retomando nosso comentário alguns parágrafos acima: é o leitor engatado com o escrito que provoca a cena. Mesmo que alguém peça para que o leitor leia, mesmo que a demanda venha do outro, é a posição subjetiva do leitor que determina a cena. Podemos identificar brevemente dois posicionamentos do leitor em voz alta, a partir da relação que este estabelece com o escrito e com a audiência.

Um primeiro tipo de leitor seria aquele que toma o escrito como sagrado, imutável. Para este leitor o sentido está dado, determinado pelo autor. A leitura em voz alta funciona como uma transcrição de materialidade gráfica para a sonora; o escrito é percebido como texto pronto e o leitor está em posição de compreender apenas, não interpretar. O leitor em voz alta deve, portanto, apresentar à audiência um texto limpo, sem erros de leitura; não há espaços vazios no escrito. A meta do leitor em relação ao espectador é devorá-lo com as palavras, alienando-o completamente ao texto, a que ele, leitor, é também 
alienado. $\mathrm{O}$ autor do texto para este leitor é um Outro todo poderoso, a quem o leitor deve se colar.

Esta é a leitura religiosa, agostiniana. Mas é também a leitura, muitas vezes promovida pela escola ou instituição em que o jogo do escrito está em garantir a circulação de um único sentido. Esta leitura em voz alta não faz circular desejo, mas incorporação, em uma identificação primitiva e devoradora; o sujeito sai de cena. Esta leitura servil, obturadora da subjetividade, pode estar relacionada ao declínio da leitura em voz alta e mesmo ao declínio da competência leitora: ler é uma atividade voluntária; o imperativo "leia" não produz outro movimento senão a completa alienação.

O segundo tipo de leitor seria aquele que considera o escrito como produto de um processo simbólico; o texto é atualizado na leitura, o leitor e a audiência participam da construção dos sentidos. Nos vazios, nos buracos, entre os parênteses, é aí que pode aparecer a leitura que faz emergir o sujeito. Ler em voz alta envolve uma experiência estética que implica a interdição do corpo pleno pelas marcas definidas na lei-dura que a língua regula e ainda a convocação de uma musicalidade, de um simbolismo sonoro, que nos remete a traços de alíngua. A leitura em voz alta transmite uma maneira singular de assujeitamento: a possibilidade de encontrarmos traços da escrita psíquica na escrita em voz alta, na escrita visível: no corpo das letras e no corpo sonoro.

Para este segundo tipo de leitor, o dito e o não-dito participam do texto. A mudança de suporte do texto - do visível para o sonoro - implica mudança de sentido. A partir deste posicionamento, o leitor se coloca em relação erótica com o texto, estabelece um diálogo com o autor em um jogo de colar/descolar, na procura de uma interpretação assinada, singular.

Esta é a leitura que invoca e que faz circular o desejo. É esta leitura que lota os ambientes em que se apresentam os leitores de La voie des Livres e do Les mots parleurs. É 
a leitura que faz transmutar ouvintes em leitores; que lança a audiência vorazmente aos livros lidos. Esta é a leitura que lembra a mãe de Canetti e a de Sartre; o Vorleser de $O$ Leitor, e da Menina que roubava livros.

Para que a leitura em voz alta interfira positivamente na apropriação da escrita pela criança, é preciso que aquele que lê para e com a criança se posicione como o segundo modelo de leitor. A cena de leitura em voz alta pode se constituir a partir daí como um lugar privilegiado de transmissão da cultura.

E o escrito? Teria a natureza, o gênero do texto, suas características discursivas, algum papel neste processo?

Acreditamos que sim. Textos poéticos, polilógicos, textos em que se joga com homofonia, repetição, nonsense, metáforas etc. parecem ser especialmente provocativos e potencializadores da emergência subjetiva, quando lidos em voz alta. Muitos deles parecem, até mesmo, chamar pela leitura em voz alta, pelo apelo que fazem ao corpo.

Contudo, lembrando mais uma vez o depoimento de Sartre: (...) a história era coisa que vinha por acréscimo (...). É possível tanto ler um manual ou uma receita de forma particular e criativa, quanto ler um romance e mesmo uma poesia de maneira enfadonha, desinteressante, monótona. A grande questão do enlace na leitura em voz alta tem origem no posicionamento do leitor e não necessariamente na natureza do texto. É o gesto de ofercer-se que está em jogo. Naturalmente, um leitor que se propõe a ler para o outro, se puder selecionar textos a serem lidos, vai buscar aqueles que mais o convocaram.

A cena de leitura em voz alta permite à criança ouviver a escrita a partir de um saboreamento, do saber as letras: torna-se assim um espaço privilegiado para uma atividade de letramento e letrante, em que a escrita em voz alta possa remeter cada um à sua escrita pessoal. 
É possível imaginar que aquilo que expusemos possa de alguma forma ressoar na escola. Uma das queixas recorrentes de crianças no consultório diz respeito à forma como os textos são pedagogizados: são apresentados e logo em seguida uma bateria de atividades, de questões de interpretação de texto. Com as crianças menores não é diferente: lê-se para a criança e em seguida a criança precisa fazer um desenho, uma brincadeira. Os livros têm “projetos”, que são utilizados como material pedagógico. A literatura infantil é vista como instrumento paradidático: a criação artística auxiliar à didática.

A leitura em voz alta, lembrando Kleinman (1993), pode ser uma atividade árdua, dolorosa e frustrante; muitas vezes as crianças abordam o texto pela primeira vez aos tropeços, o que é natural. Mas tal atividade acaba por colocar a criança que erra como alvo de críticas, chacotas. Esta leitura em voz alta afasta o leitor do texto: a incompletude é aniquiladora.

Para que a escola possa assumir plenamente seu lugar na formação de leitores, seria importante que todos os envolvidos nas práticas escolares refletissem sobre qual o modelo leitor é assumido na instituição, em que lugar o desejo e corpo são postos, e quais as implicações destas opções para a formação de leitores. Do mesmo modo, pensar o que está pressuposto quando se reduzem a arte e a cultura a recurso pedagógico e quais os efeitos estéticos, subjetivos e discursivos que se impõem nesta opção.

Entender como a escola atual toma a leitura, como leem os professores, qual o papel da leitura em voz alta são questionamentos que merecem ser explorados em profundidade em estudos posteriores.

Da mesma forma, pesquisar sobre as relações entre a natureza do escrito, a emergência subjetiva e a apropriação da escrita parece ser interessante. Ao propor suas oficinas de leitura, Kleinman (1993) opta por textos informativos e não estéticos, para dar 
conta de seus objetivos no trato do texto. No presente estudo, foram os textos marcadamente estéticos que possibilitaram a circulação do desejo e o laço com o escrito.

Nossa pesquisa faz aparecer ainda outro questionamento: como pensar a leitura em voz alta veiculada on-line, onde existe audição-observação, mas não um corpo a corpo? Durante boa parte do percurso de elaboração do presente trabalho procurei desvalorizar esta questão, mesmo sendo provocada por meu orientador. Nos momentos finais da escrita da tese encontro um texto de Moacir Scliar (2006), que me faz enxergar outras portas que ainda estão por abrir.

Em breve biografia familiar, o autor relata o lugar do livro e da leitura na constituição de sua família. Mas uma passagem me tocou especialmente: Scliar diz ter se constituído leitor e escritor a partir do desejo da mãe. Esta mulher faleceu nas complicações do parto, mas esteve presente na infância do autor pelos livros que lia quando estava grávida.

Durante a gravidez mamãe lia muito. Não para ela; lia para mim. É isso mesmo:lia para mim. $O$ sonho dela era que seu filho se tornasse um grande leitor e, se possivel, um grande escritor, autor de livros tão belos como aqueles que a emocionavam até as lágrimas. Então ela lia, em voz alta, durante horas: Monteiro Lobato, Machado de Assis, José de Alencar, Lima Barreto, Mário de Andrade. E segundo ela dizia a papai, sabia até de quais livros eu gostava mais:

- Coloque a mão aqui na minha barriga, David. Você está sentindo o nenê mexer? Está percebendo que ele bate palmas? É porque eu acabei de ler um conto de Machado de Assis. Nosso filho adora Machado de Assis, David. (Scliar, 2006, p. 63)

Scliar faz pensar que a cena de leitura em voz alta não seja necessariamente vivida em sua materialidade: a potência do Vorleser, do endereçamento desejante ao outro pode fazer criar a cena. Lendo o texto de Scliar, é quase possível ouvir uma voz rumorejando a língua. Talvez seja um caminho para pensar as relações que começam a se estabelecer a partir das práticas de leitura e escrita mediadas pela tela, pela máquina. 
Para finalizar: O rumor é o barulho daquilo que está funcionando bem (Barthes, 2004, p. 94). A cena de leitura em voz alta pode representar uma oportunidade de fazer funcionar bem a língua, o desejo, o sujeito. A leitura em voz alta rumoreja se o leitor procurar preencher seus vazios e escrever em voz alta, permitindo que aquele que o ouve, aquele que o observa, possa perceber propósitos e despropósitos, velando e desvelando sua incompletude. 


\section{REFERÊNCIAS ${ }^{35}$}

ABAURRE, M.B. M . Posfácio: A aquisição da escrita do português: considerações sobre diferentes perspectivas de análise in ROJO, R. (org.). Alfabetização e letramento Campinas: Mercado de Letras, 2006.

; FIAD, R.S.; MAURINK-SABINSON, M.L. Cenas de aquisição da escrita. Campinas: Mercado de letras, 2006.

ABREU, M. Pobres leitores pobres. Horizontes, Bragança Paulista: v.15, p. 291-323, 1997.

Agostinho, Santo. Confissões de Magistro. Tradução de J. Oliveira Santos e Ambrosio de Pina. Coleção Os Pensadores São Paulo: Editora Abril, 1973.

Editora:2002.

O Mestre. Tradução de Antonio Soares Pinheiro. São Paulo, Landy

AMIS, MARTIN O que aconteceu comigo nas férias. Água pesada e outros contos. São Paulo: Companhia das letras, 2001.

ANTUNES, A. O Silêncio in O Silêncio (BMG Ariola, 1996).

As coisas in As coisas. São Paulo: Iluminuras, 1996.

ANDRADE, M. Dicionário Musical Brasileiro. São Paulo: EDUSP, 1989.

BARROS, J. A. Os trovadores medievais e o amor cortês - reflexões Historiográficas

. A $\lambda \eta \theta \varepsilon 1 \alpha$ Ano 1. Vol.1, n.1. Disponível em

www.aletheiarevista.com/n1/artigosn1/Barros.pdf. Consultado em janeiro de 2009.

BARROS, M . Exercício de ser criança. São Paulo: Salamandra, 1999.

BABO, M A As implicações do corpo na leitura Disponível em http://bocc.ubi.pt/baboaugusta-implicacoes-corpo-leitura.html. Consultado em 20/06/2008

BAJARD, E. Ler e Dizer. São Paulo: ED. Cortez, 1994/2005.

Nova embalagem, mercadoria antiga Educação e Pesquisa, São Paulo: v. 32, n. 3, p. 493-507, set./dez. 2006.

Da escuta de textos à escrita. São Paulo: Cortez, 2007.

BARBOSA, K. ; CRESCENZO, R.; COLONHESI, L.; PASTORELLO, L. M. . Reações Observadas em Crianças Hospitalizadas a partir da Mediação de Livros Infantis. 2004. XII Congresso Brasileiro de Fonoaudiologia ; Foz do Iguaçu, 2004.

\footnotetext{
${ }^{35}$ De acordo com a Associação Brasileira de Normas Técnicas NBR 6023
} 
BARRÉ-DE MINIAC, C. La litteratie: histoire de un terme, enjeux théoriques et perspectives de recherche . Práticas Escritas na escola - letramento e representação São Paulo: USP, 2007 (333-349).

BARTHES, R. O prazer do texto. Tradução de Maria Margarida Bahona Lisboa: Edições 70, 1973.

O grau zero da escritura. Tradução de Anne Arnichand e Álvaro Lorencini. São Paulo: Cultrix, 1974. Edições 70, 1981

O grão da voz. Tradução de Teresa Meneses e Alexandre Melo. Lisboa: Fontes, 2004.

O rumor da língua. Tradução de Mário Laranjeira. São Paulo: Martins

BARTHES R. \& COMPAGNON A.Leitura, Enciclopédia Einaudi v.11 Tradução de Teresa Coelho. Imprensa Nacional /Casa da Moeda 1987.

BARTHES R. \& MARTY, E. Oral/escrito. Enciclopédia Einaudi v.11 11 Tradução de Teresa Coelho. Imprensa Nacional /Casa da Moeda 1987.

BARTHES R. \& MAURIÈS, P Escrita. Enciclopédia Einaudi v.1111 Tradução de Teresa Coelho. Imprensa Nacional /Casa da Moeda 1987.

BELLENGER, L. Os métodos de leitura. Tradução de Flora Flaksman ,Rio de Janeiro: Zahar, 1979.

BENVENISTE, E. Problemas de Lingüística Geral. São Paulo: Cia. Editora Nacional/ EDUSP, 1976.

BERBERIAN, AP. MORI-DE ANGELIS, C. Violência simbólica nas práticas de letramento in BERBERIAN, AP. MORI-DE ANGELIS, C.; MASSI, G. Letramento: Referências em saúde e educação. São Paulo: Plexus, 2006.

BELINTANE, C. Subjetividades renitentes entre o oral e o escrito. In REZENDE, N.L.; RIOLFI, C.R. SEMEGHINI-SIQUEIRA, I. Linguagem e Educação - implicações, técnicas, éticas e estéticas. São Paulo: Associação Editorial Humanitas, 2006.

Adivinha: leitura e escritura de desejo. In CALIL, E. (org.) Trilhas da escrita, Autoria, leitura e ensino. São Paulo: Cortez 2007.

Vozes da escrita: em tempo de crianças e menestréis. Texto inédito, 2008.

BERGÈS, J. Leitura e escrita literais, La psychanalyse de l'enfant 3 /4 1987. Tradução de Angela Vorcaro. 
BIRMAN, J. Corpos e formas de subjetivação. In MILNITSKY, F. (org.) Desafios da clínica psicanalítica na atualidade. Goiânia: Dimensão, 2006.

Por uma estilística da existência. São Paulo: Editora 34, 1996.

BOLOGNA, C. A voz in Enciclopédia Einaudi v.11. Tradução de Luis Fagundes Duarte. Imprensa Nacional /Casa da Moeda 1987.

BORGES, J.L. Discussão. São Paulo: Companhia das letras, 1996.

BOSI, A. Ferreira Gullar: seleção. São Paulo: Global, 2005.

BRENMAN, I. Através da vidraça da escola - Uma Reflexão sobre a Importância da Leitura em Voz Alta de Obras Literárias na Educação. Dissertação de Mestrado. Faculdade de Educação da Universidade de São Paulo, São Paulo, 2003.

BRÄKLING K. e BELINTANE, C. Fala e escrita: diferenças ou impregnações? in PEC - Formação Universitária. Secretaria Estadual de Educação de São Paulo, 2002.

BRESSON, F. A leitura e suas dificuldades in CHARTIER, R. (org.) Práticas de leitura. Tradução de Cristiane Nascimento. Estação Liberdade, São Paulo: 2001.

BOSCO, Z. R. No jogo dos significantes, a infância da letra. Tese de Doutorado. Instituto de Estudos da Linguagem da Universidade Estadual de Campinas. 1999.

BURGARELLI, C.G. Escrita e corpo pulsional. Tese de Doutorado. Instituto de Estudos da Linguagem da Universidade Estadual de Campinas. Campinas: 2003.

CANETTI, E. A língua absolvida.: histórias de uma juventude. Tradução de Kurt Jahn São Paulo: Companhia das letras, 2005.

CAGLIARI, L. C. A respeito de alguns fatos do ensino e da aprendizagem da leitura e da escrita pelas crianças na alfabetização in ROJO, R. (org.). Alfabetização e letramento Campinas: Mercado das Letras, 2006.

CALIL, E. (org.) Trilhas da escrita, Autoria, leitura e ensino. São Paulo: Cortez 2007.

CAPOVILLA, F. C.; CAPOVILLA A G. S. Intervenção em dificuldades de leitura e escrita com tratamento de consciência fonológica. In SANTOS, M.T.M. e NAVAS, A L. Distúrbios da leitura e Escrita. São Paulo: Manole, 2002.

CAYMI, Dori; PINHEIRO, P. C. Desenredo. Phillips, 1979.

CERTEAU, M. de A invenção do cotidiano. Tradução de Ephraim Ferreira Alves. Petrópolis: Vozes, 1998.

CÉU; HAIAT, Alec, Malemolência. Warner Música, 2006.

CHARTIER, R. Do livro à leitura in CHARTIER, R. (org.) Práticas de leitura. Tradução de Cristiane Nascimento. Estação Liberdade, São Paulo: 2001. 
CHARTIER, A M. - Leitura e saber ou a literatura juvenil entre ciência e ficção. In EVANGELISTA, A. A. M.; BRANDÃO, H. M. B.; VERSIANI MACHADO, M. Z. A escolarização da leitura literária - $\mathrm{O}$ jogo do livro infantil e juvenil. Belo Horizonte: Autêntica, 2003.

CHOMSKY, N. e colbs. Novas perspectivas lingüísticas. São Paulo: Vozes, 1971.

CORRÊA M. L. G Letramento e heterogeneidade da escrita no ensino do português in SIGNORINI, I. Investigando a relação oral/escrito. Campinas: Mercado das Letras, 2006.

CUNHA, A G. Dicionário Etimológico da Língua Portuguesa. Rio de Janeiro: Nova Fronteira, 1982.

DAMÁSIO, A. O erro de Descartes: emoção, razão e o cérebro humano. Tradução de Laura Teixeira Motta São Paulo: Companhia das Letras, 1996.

O mistério da consciência: do corpo e das emoções ao conhecimento de

si. Tradução de Laura Teixeira Motta.. São Paulo: Companhia das Letras, 2000.

DAUDEN, A. T. B. A criança e o outro na construção da linguagem escrita. São Paulo: Pancast, 1994.

Dicionário do estudante Alemão-português. Porto: Porto Editora, 1976.

DIDIER-WEIL, A Invocações: Dionísio, Moisés, São Paulo e Freud. Tradução de Dulce Duque Estrada. Rio de Janeiro: Companhia de Freud, 1999.

DONALDSON, J.; SCHEFFLER, A . Macaco danado. São Paulo: Brinquebook, 1999.

O Grúfalo. São Paulo: Brinquebook, 2002.

ECO, U. Lector in fábula: a colaboração interpretativa nos textos narrativos. Tradução de Attilio Cancian. São Paulo: Perspectiva, 2002.

ECO, U; BONAZZI, M. Mentiras que parecem verdades. Tradução de Giacomina Faldini. São Paulo: Summus, 1980.

FABRE, D. O livro e sua magia. In CHARTIER (org.) Práticas da Leitura. Tradução de Cristiane Nascimento. São Paulo: Estação Liberdade, 2001.

FAYOL, M.; MORAIS, J. La lecture et son apprentissage. Observatoire National de la Lecture. L'évolution de l'enseignement de la lecture en France, depuis dix ans In: Journées de l'ONL. Clermont-Ferrand. 2004. Disponível em: www.inrp.fr/ONL/ressources/publi/publications_tot.htm. Acesso em: janeiro de 2009

FERNANDES, M. Fábulas Fabulosas. São Paulo:Círculo do livro, 1976 
FINK, B. A causa real da repetição. FELDSTEIN, R; FINK, B.; JAANUS, M.(org.) Para ler o Seminário 11 de Lacan. Tradução de Dulce Duque Estrada. Rio de Janeiro: Jorge Zahar, 1997

O sujeito lacaniano: entre a linguagem e o gozo. Tradução de Maria de Lourdes Sette Câmara. Rio de janeiro: Jorge Zahar, 1998.

FONTAINE, A. A implantação do significante no corpo. Tradução de Viviane Veras. Revista Literal, Escola de Psicanálise de Campinas, n. 5, 2002, pp. 145-168.

FOUCAULT, M. O que é um autor? Tradução de António Fernando Cascais Lisboa: Passagens, 1992.

Sete proposições sobre o sétimo anjo.Coleção Ditos e Escritos III; Estética: Literatura e Pintura, Música e Cinema. Tradução de Inês Autran Dourado Barbosa. $2^{\mathrm{a}}$ ed. Rio de Janeiro: Forense Universitária, 2009.

FOUCAMBERT, J. A leitura em questão.Tradução de Bruno Charles Magne. Porto Alegre: Artes Médicas, 1994.

FREUD, S. Projeto para um psicologia científica ( 1895) Edição Eletrônica das Obras de Freud. Imago, 1980.

Psicopatologia da vida quotidiana (1901) Edição Eletrônica das Obras de Freud. Imago, 1980.

Recomendações aos médicos que exercem a psicanálise. (1912) Edição Eletrônica das Obras de Freud. Imago, 1980.

FURNARI, E. Não Confunda. São Paulo: Editora Moderna, 2002.

GARCIA, A. L. M. O desenho da escrita. Distúrbios da comunicação, 4 (2):185-189, outubro, 1991.

Dinamismo e Mimese na Linguagem. Tese de Doutorado. Campinas: UNICAMP, 1994.

GOULEMOT, J. M. Da leitura como produção de sentidos in CHARTIER (org.) Práticas da Leitura. Tradução de Cristiane Nascimento. São Paulo: Estação Liberdade, 2001.

HAVELOCK, E. A musa aprende a escrever. Tradução de Maria Leonor Santa Bárbara Lisboa: Gradiva, 1996.

ISER, WOlfGAnG. O ato da leitura - Uma Teoria do Efeito Estético vol. 2. . Tradução de Johannes Kretscmer. Rio de Janeiro: editora 34, 1996.

JAKOBSON, R. Seis lições sobre o som e o sentido. Tradução de L. M. Cintra. Lisboa: Moraes, 1977. 
JERUSALINSKY, A. A ortografia e as formações do inconsciente: novas considerações sobre a instância da letra. Estilos de Clínica - Revista sobre a Infância com Problemas. Ano VIII, número 14; dez de 2003: 20-29.

JERUSALINSKY, J. Prosódia e enunciação na clínica com bebês - quando a entonação diz mais do que se queria dizer. In VORCARO A .M.R.( org.) Quem fala na língua , Salvador : Ágalma, 2006.

JOUVE, V. A leitura. Tradução de Brigitte Hervot. São Paulo: Ed. UNESP, 2002.

KATO M. Aquisição e aprendizagem da língua materna: de um saber inconsciente para um saber metalingüístico. Investigando a linguagem, Florianópolis: ED. Mulheres, 1999.

KAUFMANN, P. Dicionário enciclopédico de psicanálise. . Tradução de Maria Luiza X. de A. Borges e Vera Ribeiro.Rio de Janeiro: Zahar, 1996.

KING, STEPHAN MICHAEL Viralata. São Paulo Brinquebook, 2005

KLEIMAN, A. Oficina de leitura: teoria e prática. Campinas: Pontes: Editora da Universidade Estadual de Campinas, 1993.

Os significados do letramento: uma nova perspectivas sobre a prática social da escrita. Campinas, Mercado de Letras: 1995.

Ação e mudança na sala de aula: uma pesquisa sobre letramento e interação. In ROJO, R. Alfabetização e letramento. Campinas: Mercado das Letras, 2006.

KRISTEVA, J. Polylogue. Paris: Éditions Du Soleil, 1977.

KUPFER, M. C. Freud e a Educação dez anos depois. Revista da Associação Psicanalítica de Porto Alegre: N 16, 1999.

LACAN, J. Subversão do sujeito e dialética do desejo no inconsciente freudiano in Escritos. Tradução de Vera Ribeiro Rio de Janeiro: Jorge Zahar, 1998.

O Seminário , livro IX - A Identificação. Inédito.

O Seminário, livro XI - Os quatro conceitos fundamentais da psicanálise. Tradução de M. D. Magno. Rio de Janiero: Jorge Zahar, 1990.

O Seminário, livro XVI - de um outro ao Outro.Tradução de Vera Ribeiro. Rio de Janeiro: Jorge Zahar, 2008.

LAJONQUIÈRE, L. Freud a educação e as ilusões (psico) pedagógicas. Revista da associação Psicanalítica de Porto Alegre: N 16, 1999.

LARRY, H. I. Coleção Zac Power (vários títulos). São Paulo: Fundamento, 2007. 
LAZNIK. M. C. A voz como primeiro objeto da pulsão oral in Estilos da Clínica Revista sobre a infância com problemas. Vol. V- número 8 - 2000.

LEMOS, C. T. G. Das vicissitudes da fala da criança e de sua investigação. Cad. Est. Ling. Campinas (42), 41-69, Jan/Jun 2002.

Sobre a aquisição da escrita: algumas questões in ROJO, R. Alfabetização e letramento. Campinas: Mercado das Letras, 2006.

Sobre o paralelismo, sua extensão e a disparidade de seus efeitos. Trabalho apresentado no V Encontro Nacional sobre Aquisição de Linguagem, realizado em Porto Alegre, na PUCRS, de dois a seis de outubro de 2000.

LEW, R. O nó vocal (as modalidades da voz como escrito). La voix, Colloque d'Ivry, Lysimaque, 1989. Tradução de Angela Vorcaro.

LIMA, S. O. A Escrita do inconsciente: do oral às possibilidades de alfabetização. In Anais do 6 Psicanálise, Educação e Transmissão, 2007. Disponível em:<http://www.proceedings.scielo.br/scielo. Consultado em 20 de janeiro de 2009.

LIVRARIA CULTURA Revista da Cultura. Número 20, março de 2009.

LISPECTOR, C. Felicidade Clandestina. Rio de Janeiro: Nova Fronteira, 1971.

LURIA, A. R. O desenvolvimento da escrita na criança. In: VIGOTSKI, L. S.; LURIA, A. R.; LEONTIEV, A. Linguagem, desenvolvimento e aprendizagem. $4^{a}$ ed. São Paulo: Icone, 1988.

MACHADO, A. M.; CLAUDIUS. Boladas e Amigos. São Paulo: Salamandra, 1988.

MADUREIRA, S. Expressividade da fala. Kyrillos, L. Expressividade, da teoria à prática. Rio de Janeiro: Revinter, 205.

MANGUEL, A. Uma história da leitura. São Paulo: Companhia das letras, 2006.

MAYRINK-SABINSON, M.L. Reflexões sobre o processo de aquisição da escrita in ROJO, R. Alfabetização e letramento. Campinas: Mercado de Letras, 2006.

MARCUSCHI, L.M. Letramento e oralidade no contexto das práticas sociais e eventos comunicativos in SIGNORINI, I. Investigando a relação oral/escrito. Campinas: Mercado das Letras, 2006.

Cortez, 2007.

Da fala para a escrita - atividades de retextualização. São Paulo:

MEIRELES C. O mosquito escreve. Ou isto ou aquilo. São Paulo: Nova Fronteira, 1990.

MESARINI, S.C. Apresentação à edição brasileira. ECO,U; BONAZZI, M. Mentiras que parecem verdades. São Paulo: Summus, 1980. 
MENDES FARIA, L; OLIVEIRA GALVÃO, A. M. [et.al.] Modos de ler/formas de escrever: estudos de história da leitura e da escrita no Brasil. Belo Horizonte: Autêntica, 2001.

MILlER, J. A. Jacques Lacan e a voz . La voix, Colloque d'Ivry, Lysimaque, 1989. Tradução de Angela Vorcaro.

MINDLIN, B. Um saber sustentável: o livro e a voz in A vida que a gente quer depende daquilo que a gente faz. Instituto Ecofuturo, 2007. (disponível em www.omelhorlugardomundo.org.br) consultado em 20 de janeiro de 2009.

MILMANN, E. A instância da letra na leitura in Estilos de Clínica - Revista sobre a Infância com Problemas. Ano VIII, número 14; dez de 2003.

OLSON, D.R. O mundo no papel: as implicações conceituais e cognitivas da leitura e da escrita. Tradução de Sergio Bath. São Paulo: Ática, 1997.

ORLANDI, E. A linguagem e seu funcionamento. Campinas: Pontes, 1996. Discurso e leitura. São Paulo: Editora Cortes, 2008.

PAIVA, A.; RODRIGUES, P.C.A. Letramento literário na sala de aula: desafios e possibilidades. In CASTANHEIRA, M.L. MACIEL. F.I.P.; MARTINS, R.M.F. Alfabetização e letramento na sala de aula. Belo Horizote: Autêntica. 2008.

PASTORELLO, L.M. As vozes da Leitura in DAUDEN, A T. B.; DE ANGELIS, C.M. (org.) Linguagem escrita: tendências e reflexões sobre o trabalho fonoaudiológico. São Paulo: Pancast, 2004.

A insistência do singular: práticas de leitura e produção da subjetividade na formação de profissionais da saúde. In BERBERIAN, AP. MORI-DE ANGELIS, C.; MASSI, G. Letramento: Referências em saúde e educação. São Paulo: Plexus, 2006.

A insistência do singular: psicanálise e formação de profissionais da saúde. In Anais do 6 Psicanálise, Educação e Transmissão, 2006 [online]. 2007 Disponível 1 em:

www.proceedings.scielo.br/scieloscript=sci_arttext\&pid=MSC000000003200700010004 $6 \& \operatorname{lng}=$ es\&nrm=iso $>$.Consultado em 20 de janeiro de 2009.

PAWEL, E. O pesadelo da razão - uma biografia de Franz Kafka. Tradução de Vera ribeiro.Rio de Janeiro: Imago, 1986.

PAZ, OCTÁVIO. Dias Hábeis. Tradução de Luís Pignatelli. Lisboa: Dom Quixote, 1984.

PÊCHEUX, M. O Discurso: estrutura ou acontecimento. Tradução de Eni Orlandi.Campinas: Pontes, 1990.

PENNAC, D. Como um romance. Rio de Janeiro: Ed. Rocco, 1993.

PICARD, M. La lecture come jeu. Paris: Editions de Minuit,1986. 
POMMIER, G. Nacimiento y Renacimiento de la Escritura Traducción Irene Agoff. Buenos Aires: Nueva Visiones, 1996.

QUINET, A . O Olhar Como Objeto. FELDSTEIN, R; FINK, B.; JAANUS, M.(org.) Para ler o Seminário 11 de Lacan. Tradução de Dulce Duque Estrada. Rio de Janeiro: Jorge Zahar, 1997.

RAMOS, G. Infância. São Paulo: Editora Recorde, 1993.

REGO, C.M. Traço, letra. Escrita: Freud, Derrida, Lacan. Rio de Janeiro: 7 letras, 2006.

RIVIÈRE, J. L. Gesto. Enciclopédia Einaudi v.11. Tradução de Teresa Coelho. Imprensa Nacional /Casa da Moeda 1987.

ROCHA, R. Marcelo, marmelo, martelo e outras histórias. São Paulo: Salamandra, 1999.

ROJO, R. Letramento escolar, oralidade e escrita em sala de aula: diferentes modalidades ou Gêneros do discurso? in SIGNORINI, I. Investigando a relação oral/escrito. Campinas: Mercado de Letras, 2006 (a).

Prefácio in CARDOSO, C.J. A sócio-construção do texto escrito. Campinas: Mercado de Letras, 2003.

O letramento na ontogênese: uma perspectiva socioconstrutivista in ROJO, R. Alfabetização e letramento. Campinas: Mercado de Letras, 2006 (b).

ROUDINESCO, E.; PLON, M. Dicionário de psicanálise. Tradução de Vera Ribeiro e Lucy Magalhães Rio de Janeiro: Jorge Zahar, 1998.

ROZA, L.A.G. Freud e o Inconsciente. Rio de Janeiro: Zahar, 1988.

SALAMERON, S. Le moi sonore. Séminaire de 08/11/96. Séminaires sur les concepts de base de la psychothérapie psichanalytique d'enfant et d'adulte. Centre Alfred Binet - Association de Santé Mentale du XIIIéme Arrondissement de Paris.

SANTAELLA, L. Navegar no cyberespaço: o perfil cognitivo do leitor imersivo. São Paulo: Paulus, 2004.

SANTOS. M. T. M. ; NAVAS, A. L. G. P. Distúrbios de Leitura e Escrita . São Paulo: Manole, 2002.

SARTRE. J. P. As palavras. Tradução de J. Guinsburg. São Paulo: Difusão Européia do Livro, 1967.

SAUSSURE, F. Curso de Lingüística geral. Tradução de Antonio Chelini, José Paulo Paes e Izidoro Blikstein. São Paulo: Cultrix, 1970. 
SCARPA, E. M. Sons preenchedores e guardadores de lugar: relações entre fatos sintáticos e prosódicos na aquisição da linguagem in SCARPA, E. M. (org.) Estudos de prosódia. Campinas: Editora da Unicamp, 1999.

SCHLINK, B. O leitor. Tradução de Pedro Süssekind. Rio de Janeiro: Record, 2009.

SCLIAR, M. Histórias de mãe e filho. LAJOLO, M. Histórias de quadros e leitores. São Paulo: Moderna, 2006.

SIGNORINI, I. Investigando a relação oral/escrito. Campinas: Mercado de Letras, 2006.

SOARES, M. Letrameneto, um tema em três gêneros. Belo horizonte: Autêntica, 2009.

SOCIEDADE BRASILEIRA DE FONOAUDIOLOGIA Documento oficial 04/2007 do Comitê de Motricidade Oral da Sociedade Brasileira de Fonoaudiologia. São Paulo, 2007.

SOLER, C. O Sujeito e o Outro II. In: FELDSTEIN, R.; FINK, B.; JAANUS, M. Para ler o Seminário 11 de Lacan. Tradução de Dulce Duque Estrada. Rio de Janeiro: Jorge Zahar, 1997, p. 58-67.

SOUZA, P. O corpo móvel da escrita em exercícios virtuais na internet in CALIL, E. (org.) Trilhas da escrita, Autoria, leitura e ensino. São Paulo: Cortez 2007.

STODDART, W. O hinduísmo. São Paulo: IBRASA, 2005.

TAVARES, E.S. No reino dos pequeninos. Revista da Associação Psicanalítica de Porto Alegre. Ano VIII: 15 (103-109), novembro de 1988.

TFOUNI, L.V. A dispersão e a deriva na construção da autoria e suas implicações para uma teoria do letramento in SIGNORINI, I. Investigando a relação oral/escrito. Campinas: Mercado das Letras, 2006.

THOMPSON, C. Como viver para sempre. São Paulo: Brinque Book, 2008

VERÍSSIMO L. F. O analista de Bagé. Porto Alegre: L\&PM, 1982.

VIOLA, I. O gesto vocal: a arquitetura de um ato teatral. Tese de Doutorado. Pontifícia Universidade Católoca de São Paulo, Departamento de Lingüística Aplicada, 2006.

VORCARO, A. M. R. O jogo ou o ponto de imbricação entre educação, psicanálise e lingüística in Anais do $3^{\mathbf{0}}$ Colóquio de LEPSI IP/FE-USP Oct. 2001.

VYGOTSKY, L.S. A formação social da mente. São Paulo: Martins Fontes, 1998.

WOOD,A;WOOD, D. A casa sonolenta. São Paulo: Ática, 2002. 
WOOLF, V. O leitor comum. Tradução, seleção e notas de Luciano Viègas. Rio de Janeiro: Graphia, 2007.

ZILBERMAN, R. O leitor e o livro. Horizontes, Bragança Paulista: v.15, p. 21-40, 1997.

ZUMTHOR, P. Performance, recepção, leitura. Tradução de Jerusa Pires Ferreira e Suely Fenerich. São Paulo: Cosac Naify, 2007.

ZUSAK, M. A menina que roubava livros. Tradução de Vera Ribeiro. Rio de Janeiro: Intrínseca, 2007. 